Check for updates

Cite this: RSC Adv., 2017, 7, 18724

Received 14th February 2017

Accepted 21st March 2017

DOI: $10.1039 / c 7 r a 01845 b$

rsc.li/rsc-advances

\section{Phosphonium carbosilane dendrimers for biomedical applications - synthesis, characterization and cytotoxicity evaluation $\uparrow$}

\author{
Tomáš Strašák, ${ }^{* a}$ Jan Malý, (D) *b Dominika Wróbel, ${ }^{\mathrm{b}}$ Marek Malý, ${ }^{\mathrm{c}}$ Regina Herma, \\ Jan Čermák, ${ }^{\text {ad }}$ Monika Müllerová, ${ }^{a}$ Lucie Červenková Št'astnáa and Petra Cuřinováa
}

\begin{abstract}
We report the synthesis and cytotoxicity evaluation of a completely new class of cationic carbosilane dendrimers functionalized with several different phosphonium peripheral groups and an ammonium functionalised one as a reference. The carbosilane dendrimers with $\mathrm{NMe}_{3}, \mathrm{PMe}_{3}, \mathrm{P}\left(\mathrm{Et}_{2}\right)_{2}\left(\mathrm{CH}_{2}\right)_{3} \mathrm{OH}, \mathrm{PBu}_{3}$, $\mathrm{P}\left(\mathrm{C}_{6} \mathrm{H}_{4}-\mathrm{OMe}\right)_{3}$ and $\mathrm{P}(\mathrm{Ph})_{3}$ peripheral substituents were synthesized, thoroughly characterized and modelled by computer simulations. The cytotoxicities of the dendrimers were investigated in vitro on three model cell lines (B14, BRL and NRK cells) by MTT and CV assay methods. Generally, the cytotoxicities of $\mathrm{PMe}_{3}$ carbosilane dendrimers were similar or slightly lower when compared with $\mathrm{NMe}_{3}$ dendrimers. The substitution of methyl groups in $\mathrm{PMe}_{3}$ carbosilane dendrimers with more hydrophobic and bulky alkyl substituents $\left(\mathrm{PBu}_{3}\right.$ and $\mathrm{P}\left(\mathrm{Et}_{2}\right)_{2}\left(\mathrm{CH}_{2}\right)_{3} \mathrm{OH}$ dendrimers) resulted in an increase of cytotoxicity. The $\left.\mathrm{P}_{(} \mathrm{C}_{6} \mathrm{H}_{4}-\mathrm{OMe}\right)_{3}$ dendrimer showed exceptionally low cytotoxicity across all cell lines or assay methods used. Generally, phosphonium carbosilane dendrimers could represent a valuable alternative to ammonium ones in gene therapy applications due to comparable or lower cytotoxicities, the presence of positive charge for nucleic acid electrostatic binding and in the cases of $\left.\mathrm{P}_{(} \mathrm{C}_{6} \mathrm{H}_{4}-\mathrm{OMe}\right)_{3}$ and $\mathrm{P}(\mathrm{Ph})_{3}$ dendrimers high potential of mitochondrial targeting.
\end{abstract}

\section{Introduction}

Recently, numerous types of drug delivery systems (DDS) have been studied for nonviral gene delivery to treat various genetic diseases such as cystic fibrosis, haemophilia, cancer or several types of infection diseases. ${ }^{1}$ Cationic polymers and lipids, able to interact by electrostatic interactions with negatively charged nucleic acids are used for the formation of dendriplexes and lipoplexes. Such nanoparticles stabilize DNA or RNA, protect them from degradation by nucleases, enable their cellular uptake by endocytosis and finally cause endosomal escape

aInstitute of Chemical Process Fundamentals of the CAS, v. v. i. Rozvojova 2/135, CZ-165 02 Prague 6 - Suchdol, Czech Republic. E-mail: strasak@icpf.cas.cz

${ }^{b}$ Department of Biology, J.E. Purkyně University, České mládeže 8, 40096 Usti nad Labem, Czech Republic. E-mail: malyjalga@seznam.cz

${ }^{c}$ Department of Physics, J. E. Purkyně University, České mládeže 8, 40096 Usti nad Labem, Czech Republic

${ }^{d}$ Department of Chemistry, J.E. Purkyně University, 40096 Usti nad Labem, Czech Republic

$\uparrow$ Electronic supplementary information (ESI) available: ESI focuses on the following additional information: graphs from ${ }^{1} \mathrm{H},{ }^{13} \mathrm{C}$ and ${ }^{29} \mathrm{Si}$ NMR analysis (Fig. S1-S69); ESI HRMS of compound 31 and 32 (Tables S1 and S2); details on the solubility of prepared compounds in water (Table S3); calculated values of electrostatic potential on the molecular surface of G3 dendrimers (Table S4); evaluation of G2 and G1 dendrimers cytotoxicity based on $\mathrm{IC}_{50}$ values (Fig. S70 and S71). See DOI: 10.1039/c7ra01845b finished by release of genetic material into the cytoplasmic space or nucleus. ${ }^{2}$ Among the other polymeric systems, cationic dendrimers (DDMs) such as the commercially available poly(amidoamine) (PAMAM) dendrimers have been shown to be effective for in vitro cell transfection..$^{3-6} \mathrm{Up}$ to now, most of the dendrimer-based gene delivery systems were surface modified by nitrogen-containing cationic groups including ammonium cations. ${ }^{7}$

Despite their successful in vitro application, the toxicity of positively charged amine groups is the main obstacle for in vivo use of dendrimers and the other cationic vectors as gene delivery vehicles. ${ }^{7}$ Several different approaches were presented, which address this problem by surface engineering of dendrimers with low-toxic outer shell, shielding the positively charged groups present in the inner layer of dendrimer. Modification of dendrimers with poly(ethylene)glycol, ${ }^{7-10}$ carbohydrates, ${ }^{11-14}$ amino acids, ${ }^{15}$ acetyls ${ }^{16}$ or by attaching targeting ligands (peptides, proteins) ${ }^{\mathbf{1 7}}$ was described and their resulting lower cytotoxicity compared with unmodified cationic dendrimers demonstrated. On the other hand, a compromise between the toxicity, ability to complex nucleic acids and transfection efficacy of such nanoparticles has to be always considered.

Apart from surface functional groups, the core and branching units of dendrimer can also contribute to the overall toxicity. New less toxic DDMs having biodegradable core or less 
cytotoxic branching units were therefore synthesized. As an example, the polyester, ${ }^{18}$ polyether imine, ${ }^{19}$ phosphate $^{20}$ or triazine $^{21,22}$ low-toxic DDMs were synthesized. Another promising DDS candidates of this group are carbosilane dendrimers (CS-DDMs). ${ }^{11,23-28}$ For example, low toxicity of the second generation ammonium-terminated CS-DDMs was proven by several complementary approaches. ${ }^{27}$ It was also shown that these cationic DDMs favourably interact with anti-HIV oligodeoxyribonucleotides and form dendriplex nanoparticles, suitable for cell transfection. ${ }^{23}$ The siRNA delivery into the brain by carbosilane dendrimers was also reported. ${ }^{28}$

Beside this, much less effort has been focused on investigations of dendrimer modifications by other types of positively charged groups, like e.g. phosphonium or arsenium cationic moieties. As was already demonstrated, such cationic groups are able to substitute primary amines or ammonium groups in lipid or polymer-based transfectant molecules with significantly lower cytotoxicity and higher transfection efficiency. ${ }^{29-31}$ As an example, phosphonium- and arsenium-containing lipids have shown ability to bind DNA and to mediate higher gene transfection with lower cytotoxicity in comparison with the ammonium-based analogs in vitro and in vivo ${ }^{32-34}$. Similarly, phosphonium-containing $\mathrm{AB}$ diblock copolymers, which efficiently complexed pDNA to generate core-shell nanoparticles were also reported. Resulted polyplexes demonstrated HepaRG cells specific transfection and low cytotoxicity. ${ }^{29}$ The same group of authors also systematically investigated the role of variable length of alkyl substituent attached to the phosphonium cation in DNA complexation and transfection efficiency of different cell lines. ${ }^{31}$ The synthesis of phosphonium polymeric material for nucleic acid transfection consisting of polyacrylate polymer backbone modified with phosphonium groups has been reported. ${ }^{30}$ Further on, in agreement with other studies, ${ }^{29}$ systematic investigation has shown important influence of different types of alkyl substituents on the phosphonium cations on transfection efficiency and toxicity of polyplexes. ${ }^{30}$

Despite the proved benefits in other types of transfection materials, there exist only few attempts to synthesize dendrimers with phosphonium surface groups and to use them for gene delivery applications. ${ }^{35-37}$ Most of the work done was based on surface group modification of PAMAM dendrimers. As an example, mitochondria-targeted dendrimer was synthesized via the acid-amine-coupling conjugation reaction between the acid group of (3-carboxypropyl)triphenylphosphonium bromide and the primary amines of the acetylated generation 5 poly(amidoamine) (PAMAM) dendrimer. Resulting triphenylphosphonium (TPP)-anchored dendrimer was efficiently taken up by the cells and demonstrated mitochondrial targeting with greater cell viability on fibroblast cells (NIH-3T3) as compared to unmodified PAMAM- $\mathrm{NH}_{2}$ dendrimer. ${ }^{37}$ In the similar way, an efficient HeLa and COS-7 cells transfection with EGFP and luciferase reporter gene expression plasmids has been shown. Transfection efficacy was improved in comparison with commercial transfectants Lipo2000 and unmodified dendrimers along with decreased cytotoxicity. ${ }^{36}$ Apart from those two literature examples, which focused solely on TPP surface modification of PAMAM dendrimers, no systematic comparative investigation of different types of phosphonium groups on dendrimer cytotoxicity and eventually, transfection efficacy has been presented.

Herein we present synthesis and characterization of completely new class of generation 1-3 carbosilane dendrimers surface modified with various types of phosphonium groups and one type of ammonium terminated CS-DDM for comparison. The core of carbosilane dendrimers was synthesized based on our previous work on synthesis of CS-DMMs functionalized with titanocene moieties. ${ }^{\mathbf{3 8 - 4 1}}$ Ammonium and phosphonium groups were connected by quaternization of trimethyl amine or an appropriate phosphine by iodopropyl-terminated dendrimers. To manifest their potential in biomedical applications, we have performed comparative in vitro cytotoxicity studies on three model cell lines.

\section{Results and discussion}

\subsection{Synthesis and characterization of dendrimers}

The cationic dendrimers were prepared by the sequence of reactions as shown in Scheme 1. In the first step carbosilane

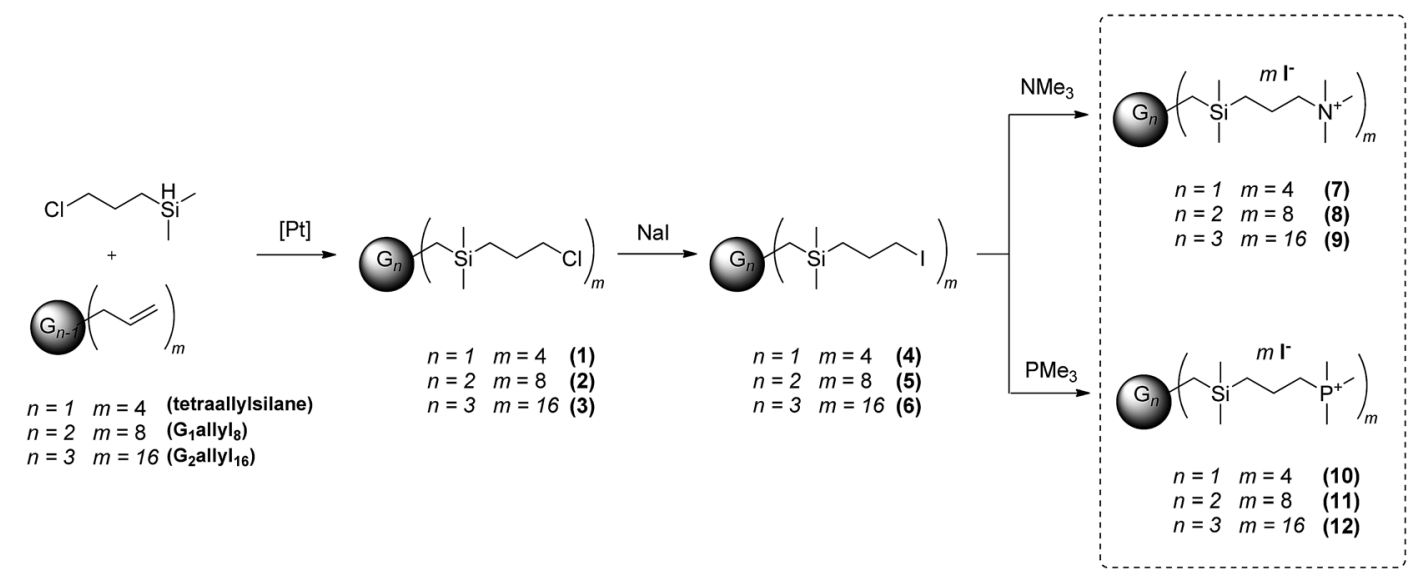

Scheme 1 Synthesis of trimethylonium salts terminated carbosilane dendrimers. 
dendrimers with 3-chloropropyl terminal groups were synthesized via hydrosilylation of allyl-terminated starting compounds by (3-chloropropyl)dimethylsilane. The reactions were performed in Schlenk tubes using pentane as solvent and the Karstedt catalyst. The progress of the reactions was monitored by ${ }^{1} \mathrm{H}$ NMR spectroscopy. The most significant signals of the starting compounds are those of the terminal double bonds consisting of one doublet at $c a . \delta 1.8$ and two multiplets at $c a$. $\delta 5.4$ and 6.0 in ${ }^{1} \mathrm{H}$ NMR spectra and three resonances at $c a$. $\delta 22.9,128.3$, and 143.1 in ${ }^{13} \mathrm{C}$ NMR spectra. Disappearance of these signals indicates the completeness of reaction. No side products resulting from undesired $\alpha$-hydrosilylation leading to branched alkyl spacers in the structure were detected. Siloxane, which was sometimes observed as the product of hydrolysis followed by condensation of (3-chloropropyl)dimethylsilane was removed by evaporation in high vacuum. The chloropropyl functionality was subsequently transformed to iodopropyl by Finkelstein reaction. The triplets of the methylenes connected to halogens are after the substitution shifted to higher field from $3.50 \mathrm{ppm}$ for chloride to $3.18 \mathrm{ppm}$ for iodide. As the starting uncharged dendrimers 1-6 were not easily ionisable, even using APCI ionization technique, a different approach was employed. The compounds were dissolved in chloroform, a few drops of methanol were added followed by addition of ammonium formate buffer. These solutions were then measured using ESI source in the positive mode resulting in observation of $\left[\mathrm{M}+\mathrm{NH}_{4}\right]^{+}$ions. Different synthetic protocol based on hydrosilylation of bromoalkenes by $\mathrm{Si}-\mathrm{H}$ terminated carbosilane dendrimers was employed by De la Mata et al. for preparation bromo-terminated carbosilane dendrimers with longer spacer. $^{42}$
The last step of the synthesis consists in the formation of onium salts on the periphery of dendrimers. The quarternisation reaction with 3-iodopropyl-terminated dendrimers was carried out in acetonitrile with slight excess of trimethylamine or an appropriate phosphine. Insoluble starting hydrophobic dendrimers became gradually soluble in acetonitrile as soon as the number of onium groups created on the periphery was sufficient to transfer compounds into solution. After completion of the reaction, the excess of amine or phosphine was extracted in toluene. Depending on terminal groups, the products were isolated as white solids or liquids having variable viscosity.

In this manner we prepared a series of carbosilane dendrimers decorated by onium salts on the periphery. For ammonium-phosphonium comparative study we synthetized a series of methylated analogues which differ only in cationic centre i.e. nitrogen (7-9) or phosphorus (10-12) atom. As expected, due to the much higher nucleophilicity of phosphines toward carbon compared with amines, quaternization of amines requires longer reaction time to achieve fully substituted product. For ammonium derivatives (7-9) was recently published procedure based on quaternization of amino groups on periphery of dendrimers with an excess of MeI. ${ }^{43}$

The above described synthetic procedure was followed also in the synthesis of a new family of phosphonium-terminated dendrimers (Scheme 2). Representative groups having diverse environments of cationic centres were designed and characterized. The NMR spectroscopic and analytical data for all derivatives are consistent with their proposed structures. The presence of $\mathrm{Si}\left(\mathrm{CH}_{2}\right)_{3} \mathrm{P}$ unit in molecule was documented by a doublet of outer silicon atoms in ${ }^{29} \mathrm{Si}\left\{{ }^{1} \mathrm{H}\right\} \mathrm{NMR}$, typically with coupling constant ${ }^{4} J_{\mathrm{SiP}}$ ca. $2.5 \mathrm{~Hz}$ (Fig. 1). However chemical

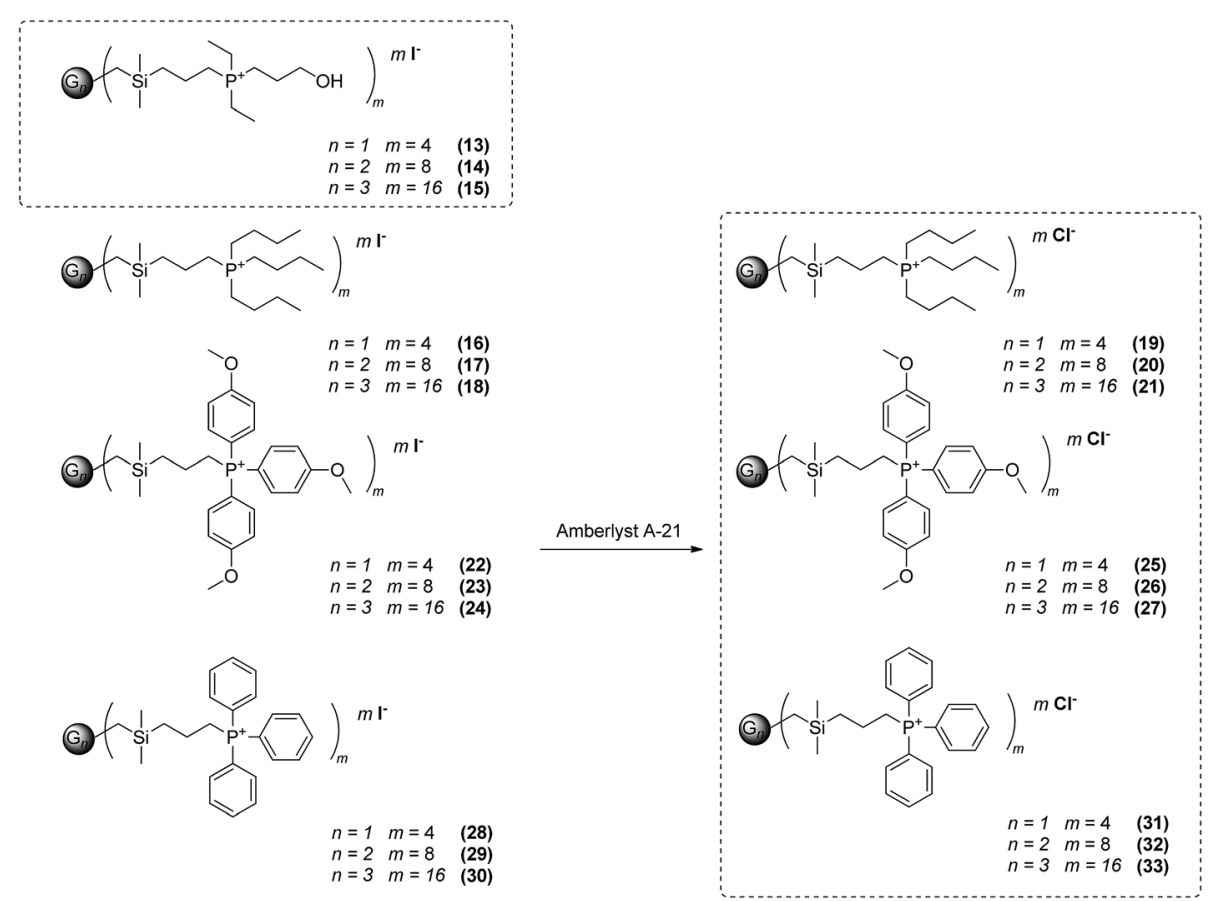

Scheme 2 Phosphonium carbosilane dendrimers synthesized in this work. 


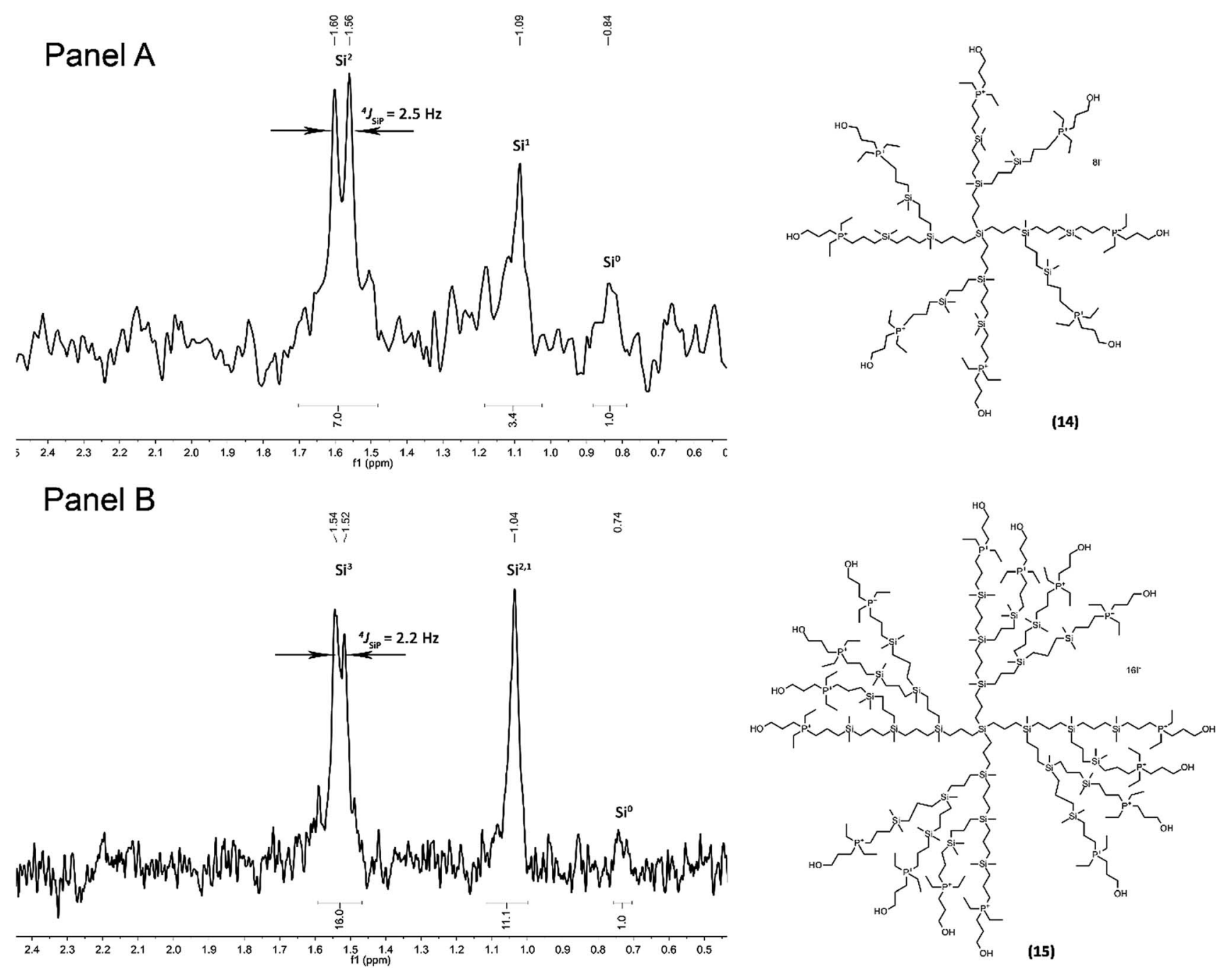

Fig. 1 Dendrimer structure and ${ }^{29} \mathrm{Si}\{1 \mathrm{H}\}$ NMR. Panel A: compound 14; panel B: compound 15.

shifts in ${ }^{29} \mathrm{Si}\left\{{ }^{1} \mathrm{H}\right\}$ NMR showed no significant change with respect to the environment of phosphorus atom. ${ }^{31} \mathrm{P}\left\{{ }^{1} \mathrm{H}\right\}$ NMR was in this sense more sensitive. Signals occurred in the range from about $21 \mathrm{ppm}$ for methoxyphenyl-terminated dendrimers to $43 \mathrm{ppm}$ for dendrimers 13-15. In the case of all quarternary ammonium or phosphonium salts, the ions were easily observable via electrospray ionisation. Due to the ability of target dendrimer molecules to form multiply charged species, almost all the possible cations were observed in each case (for example, if the dendrimer structure is Dend. $\mathrm{P}_{n} \mathrm{I}_{n}$, all the possible [Dend. $\left.\mathrm{P}_{n} \mathrm{I}_{n-i}\right]^{i+}$ ions are formed) (see Tables S1 and S2†). This feature offers an opportunity to observe counteranions in the positive mode, which simplifies the monitoring of $\mathrm{I}^{-} / \mathrm{Cl}^{-}$ion exchange reaction leading to the compounds 19-21, 25-27 and 31-33.

Solubility in aqueous solutions is a critical parameter for applicability of dendrimers in biological systems and their use in biomedical applications. Because of the inherent hydrophobicity of the interior of carbosilane dendrimers the appropriate solubility behaviour can be achieved by targeted design of peripheral groups. The solubility of onium salts is known to be strongly dependent on counter-anion, ${ }^{44}$ therefore ion exchange was suggested as a useful method to enhance solubility in water. Dendrimers containing butyl (16-18), methoxyphenyl (22-24) and phenyl (28-30) substituents showed only negligible solubility in water when the counteranion was the iodide ion despite being well soluble in polar aprotic solvents such as DMSO, acetonitrile, but also in methanol. To enhance water solubility of poorly soluble compounds we exchanged the iodide anions for chloride using ion exchange resign with the result of increasing the solubility in water considerably. For example solubility of all dendrimers with butyl groups was increased from $<5 \mathrm{mg} \mathrm{mL}^{-1}$ for derivatives with iodine to $>100 \mathrm{mg} \mathrm{mL}{ }^{-1}$ for those with chloride anion. Table S3 $\uparrow$ summarizes typical values of solubility of prepared compounds in water.

\subsection{Computer modelling of dendrimers}

To obtain detailed information about the shape, size, space distribution of peripheral groups etc. of all dendrimers in water, 
Panel A: Simulated dendrimer structures

A

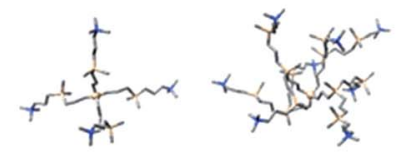

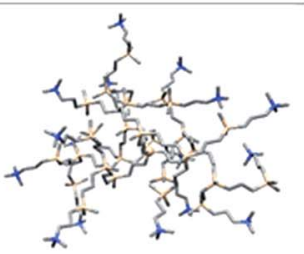

B

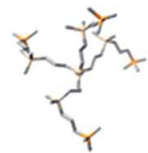

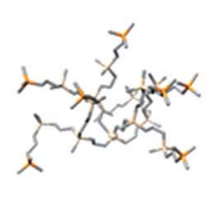

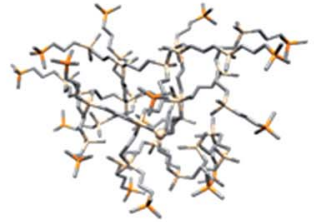

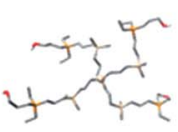

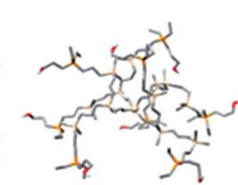

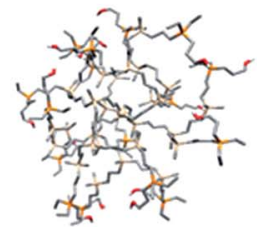

D

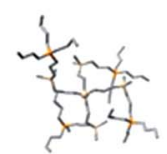

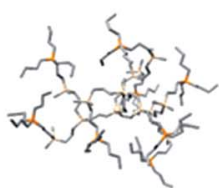
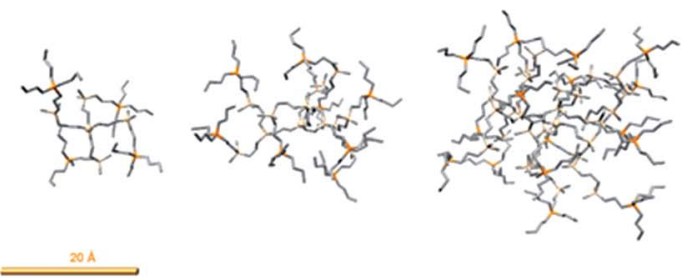

E
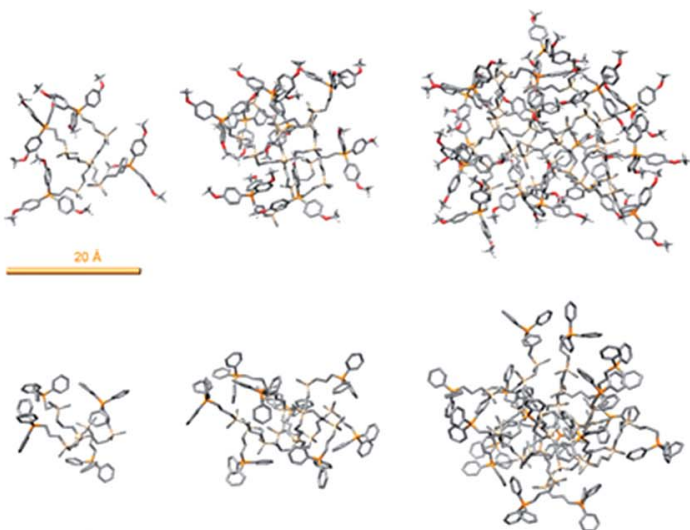

\section{Panel B: Radial Distribution Functions}
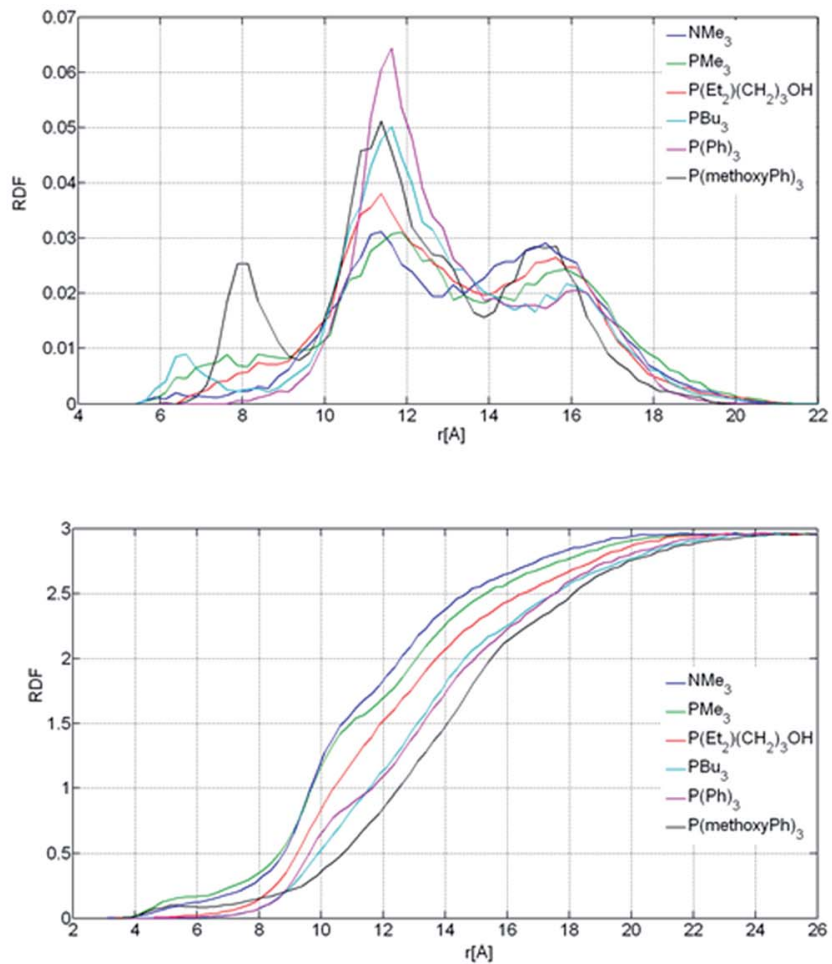

Panel C: G3 dendrimer molecular surfaces

A

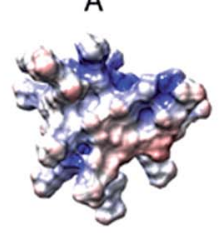

D

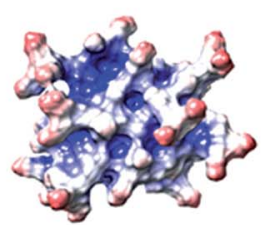

B
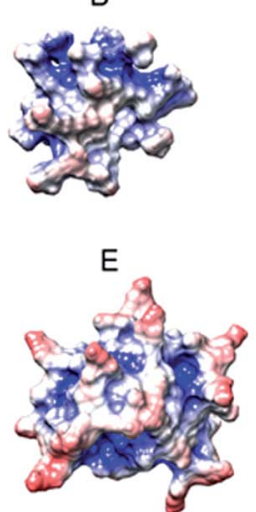

C

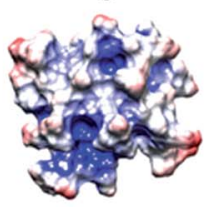

$\mathrm{F}$

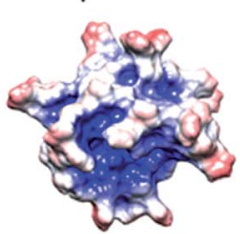

Fig. 2 Computer models of dendrimer structures and their characteristics. Panel A: Simulated dendrimer structures. The first (G1, left), second (G2, middle) and third (G3, right) generations are shown. (A) $\mathrm{NMe}_{3} ;(\mathrm{B}) \mathrm{PMe}_{3} ;(\mathrm{C}) \mathrm{P}_{(\mathrm{Et}} \mathrm{Et}_{2}\left(\mathrm{CH}_{2}\right)_{3} \mathrm{OH}$; (D) $\mathrm{PBu} ;$; $(\mathrm{E}) \mathrm{P}\left(\mathrm{C}_{6} \mathrm{H}_{4}-\mathrm{OMe}\right)_{3} ;(\mathrm{F}) \mathrm{P}(\mathrm{Ph})_{3}$. Hydrogens are omitted (except those attached to oxygens or those belonging to terminal methyl groups attached to oxygens) for better clarity. Orange scale bar denotes length 20 A. Colours: C - grey; O - red; H - white; Si - beige; N - blue; P - orange. Panel B: Radial distribution functions (relative density profiles, RDF) of terminal $\mathrm{P}(\mathrm{N})$ atoms with respect to central Si atom in case of $3^{\text {rd }}$ generation dendrimers (upper graph); RDF of water with respect to central Si atom (just G3, lower graph). Panel C: simulated dendrimer structures (just G3) with molecular surface shown, which is coloured based on electrostatic potential. (A) NMe $;$; (B) PMe $;$; (C) $\mathrm{P}\left(\mathrm{Et}_{2}\right)_{2}\left(\mathrm{CH}_{2}\right)_{3} \mathrm{OH} ;(\mathrm{D}) \mathrm{PBu} ;(\mathrm{E}) \mathrm{P}\left(\mathrm{C}_{6} \mathrm{H}_{4}-\mathrm{OMe}\right)_{3} ;(\mathrm{F}) \mathrm{P}(\mathrm{Ph})_{3}$. Red lower potential ( $0 \mathrm{~V}$ and less); white - potential $0.063 \mathrm{~V}$; blue - higher potential $\left(0.127 \mathrm{~V}\right.$ and higher). Influence of water, $\mathrm{Na}^{+}$and $\mathrm{Cl}^{-}$is taken implicitly in an account (APBS calculation).

their computer simulation models were studied using molecular dynamics in explicit water. Models show that higher generation dendrimers maintain spherical shape (Fig. 2 panel
A). Calculated radii of gyration $\left(R_{\mathrm{g}}\right)$ and "geometric radii" $\left(R_{\max }\right)$ are shown in Table 1. The sizes of $\mathrm{NMe}_{3}$ and $\mathrm{PMe}_{3}$ dendrimers, which have the same structure except terminal (quaternized) 
Table 1 The size characteristics of dendrimers. $R_{\mathrm{g}}$ - radius of gyration of the simulated dendrimer structures, $R_{\max }-$ maximal distance of the dendrimer atoms from the dendrimer center of geometry (for spherical molecules estimate of their radius). In each cell of the table the average value and standard deviation is presented

\begin{tabular}{|c|c|c|c|c|c|c|}
\hline & $\mathrm{NMe}_{3}$ & $\mathrm{PMe}_{3}$ & $\mathrm{P}\left(\mathrm{Et}_{2}\right)_{2}\left(\mathrm{CH}_{2}\right)_{3} \mathrm{OH}$ & $\mathrm{PBu}_{3}$ & $\mathrm{P}\left(\mathrm{C}_{6} \mathrm{H}_{4}-\mathrm{OMe}\right)_{3}$ & $\mathrm{P}(\mathrm{Ph})_{3}$ \\
\hline \multicolumn{7}{|c|}{$\boldsymbol{R}_{\mathrm{g}}[\AA]$} \\
\hline G3 & $10.80 \pm 0.21$ & $10.83 \pm 0.20$ & $11.94 \pm 0.25$ & $12.47 \pm 0.21$ & $13.10 \pm 0.20$ & $12.66 \pm 0.17$ \\
\hline G1 & $6.98 \pm 0.31$ & $7.27 \pm 0.30$ & $7.91 \pm 0.56$ & $8.13 \pm 0.41$ & $8.04 \pm 0.29$ & $7.90 \pm 0.42$ \\
\hline \multicolumn{7}{|c|}{$\boldsymbol{R}_{\max }[\AA]$} \\
\hline G1 & $12.36 \pm 0.79$ & $12.79 \pm 0.74$ & $13.77 \pm 1.11$ & $15.07 \pm 1.16$ & $15.52 \pm 0.85$ & $14.12 \pm 0.84$ \\
\hline
\end{tabular}

atoms ( $\mathrm{N}$ or $\mathrm{P}$ ), are almost identical in all generations. The other structures are slightly bigger than those two structures $\mathrm{P}\left(\mathrm{C}_{6} \mathrm{H}_{4}^{-}\right.$ $\mathrm{OMe})_{3}$ dendrimer being the biggest.

Radial distribution functions of dendrimer atoms and water with respect to the central $\mathrm{Si}$ atom were calculated for the $3^{\text {rd }}$ generation (G3) dendrimers. Density analysis of terminal $\mathrm{P}(\mathrm{N})$ atoms revealed more pronounced back-folding in case of $\mathrm{PMe}_{3}$ dendrimer ( $c a$. 6-9 $\mathrm{A}$ area from central Si atom) compared with $\mathrm{NMe}_{3}$ which has higher density in more distant area (ca. 13-16 $\AA)$. Otherwise the density profiles of those two dendrimers are quite similar. Furthermore, the density profiles have rather similar shape in all dendrimers showing one main peak around ca. $11.5 \AA$ and one secondary peak at $c a .15 .5 \AA$ distance from the central $\mathrm{Si}$ atom. $\mathrm{P}\left(\mathrm{C}_{6} \mathrm{H}_{4}-\mathrm{OMe}\right)_{3}$ dendrimer has one additional remarkable peak at $8 \AA$ indicating back-folded branch/es (see Fig. 2 panel B, upper graph). Radial density profiles of water with respect to central Si atom are shown at Fig. 2 panel B, lower graph. Dendrimers with the most hydrated interior are $\mathrm{NMe}_{3}$ and $\mathrm{PMe}_{3} \cdot \mathrm{NMe}_{3}$ is slightly more hydrated than $\mathrm{PMe}_{3}$ dendrimer. $\mathrm{P}\left(\mathrm{C}_{6} \mathrm{H}_{4}-\mathrm{OMe}\right)_{3}$ dendrimer has the smallest water density in majority of its interior when compared with other dendrimer types.

Fig. 2 panel C shows molecular surfaces of dendrimers (G3) coloured according to their electrostatic potential. As presented in Table S4 (see ESI $\dagger$ ) the average value of surface potential is very similar (around $0.14 \mathrm{~V}$ ) for all structures but there are more significant differences in the range of electrostatic potential values (min, max) and standard deviation.

\subsection{In vitro cytotoxicity evaluation}

To determine the potential of biomedical applications of novel class of dendrimers presented, we have further focused on investigation of their cytotoxicity, as one of the most important parameters which influence and limit the practical use of the majority of drug delivery systems. Cytotoxicity profiles of carbosilane dendrimers terminated with different phosphonium and $\mathrm{NMe}_{3}$ functional groups were investigated in vitro on three model cell lines (B14, BRL and NRK cells) with the aim to reflect the potential tissue/cell type related variations. Two methods were used to determine the effect of dendrimers on cell viability. The first one was MTT assay, the method which is based on monitoring of $\mathrm{NAD}(\mathrm{P}) \mathrm{H}-$ dependent cellular oxidoreductase enzymes activity and is therefore related to inhibition of metabolic processes in mitochondria. The other method was the crystal violet (CV) staining assay. This method is based on crystal violet property to stain cell's DNA and is therefore connected to number of cells after cultivation experiment (monitors the inhibition of the cell growth).

With the aim to investigate the main parameters influencing the toxicity profiles of individual dendrimer types, cell viability was plotted in logarithmic concentration scale (Fig. 3) and fitted with four-parameter logistic function (4PL function, $R^{2}>0.95$ ) using nonlinear regression analysis as described in Experimental section (see Section 4.5). Based on the calculated parameters of each curve, the $\mathrm{IC}_{50}$ values (concentration of dendrimers which inhibits the cell viability to $50 \%$ of the control sample) were obtained (Table 2) and used for further evaluation of dendrimer cytotoxicity. Toxicity of dendrimers was studied based on $\mathrm{IC}_{50}$ as variable of dendrimer type, generation, assay method and cell line.

2.3.1 Influence of dendrimer peripheral groups on cytotoxicity. As is apparent from Fig. 4 (generation 3) and Fig. S70 and $\mathrm{S} 71 \uparrow$ (generation 2,1) there is no simple relative order of toxicity of individual types of dendrimers which holds for all experimental variants and assay methods investigated. More likely it is possible to recognize some groups or individual types which differ from the rest of the dendrimers according to the specific conditions of experiment. Focusing first on the phosphonium and ammonium dendrimers with methyl groups $\left(\mathrm{NMe}_{3}\right.$ - dendrimer 7-9 and $\mathrm{PMe}_{3}$ - dendrimer 10-12) quite similar cytotoxic effect with $\mathrm{IC}_{50}$ in the order of $2-50 \mu \mathrm{M}$ (based on the cell type and generation) was observed by MTT method. This is in good agreement with previously published results ${ }^{27}$ of $\mathrm{NMe}_{3} 2^{\text {nd }}$ generation carbosilane dendrimers cytotoxicity with the $\mathrm{IC}_{50}$ measured by MTT assay in the range of 1-10 $\mu \mathrm{M}$. In comparison with other types of dendrimers, those two dendrimers stay always close together in relative order of toxicity showing slightly less toxic effect (exception being $\mathrm{P}\left(\mathrm{C}_{6} \mathrm{H}_{4}-\mathrm{OMe}\right)_{3}$ dendrimer 25-27 as discussed further) on mitochondria (MTT assay), but have very similar effect on inhibition of cell growth with other types of dendrimers $\left(\mathrm{CV}\right.$ assay, $\mathrm{IC}_{50}=2-160 \mu \mathrm{M}$ based on cell type and dendrimer generation). $\mathrm{PMe}_{3}$ dendrimer was significantly less toxic when compared with $\mathrm{NMe}_{3}$ one on B14 cells. This applies to all generations measured by MTT and 

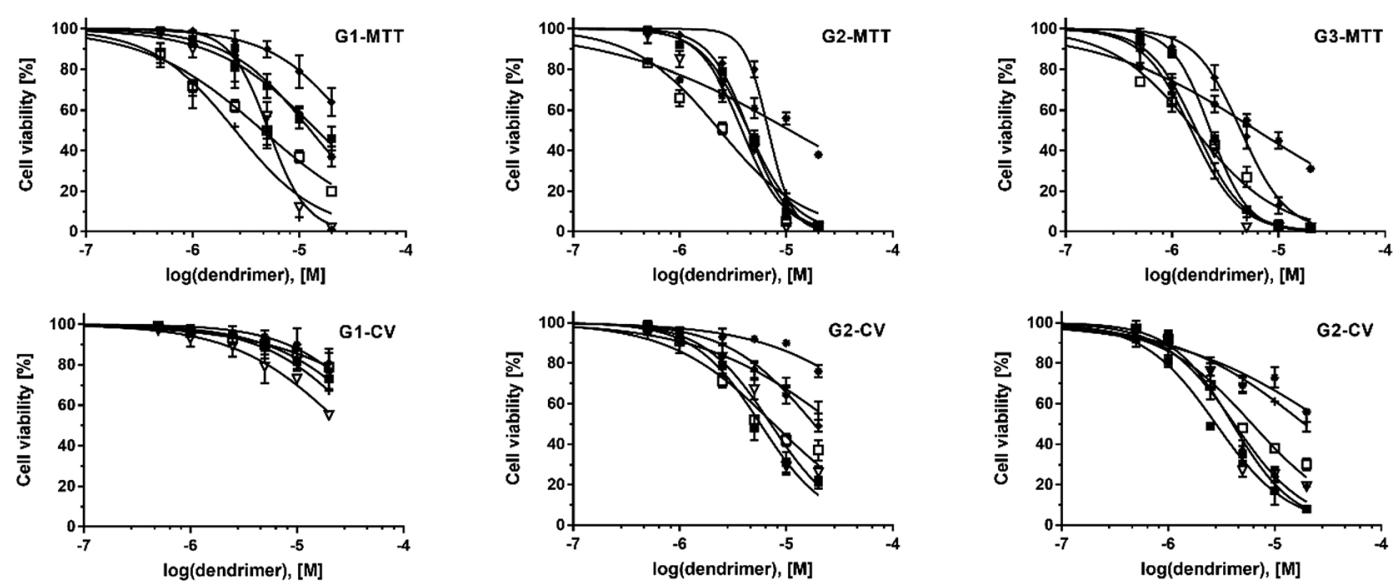

BRL cells
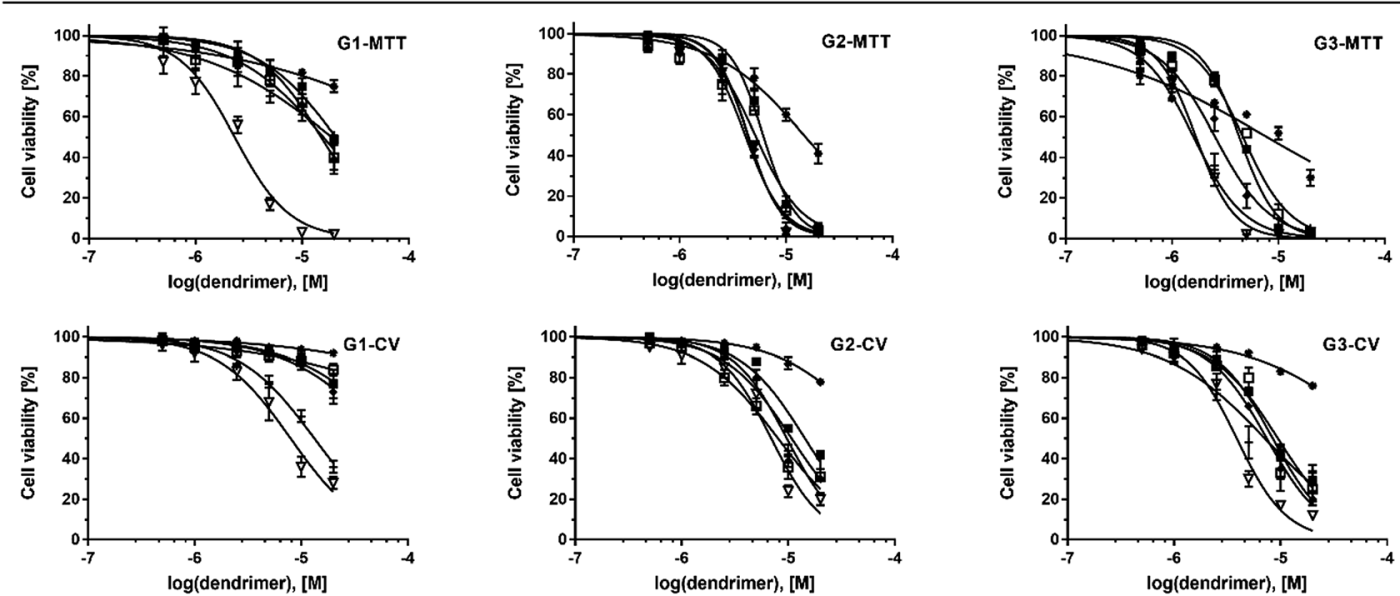

NRK cells
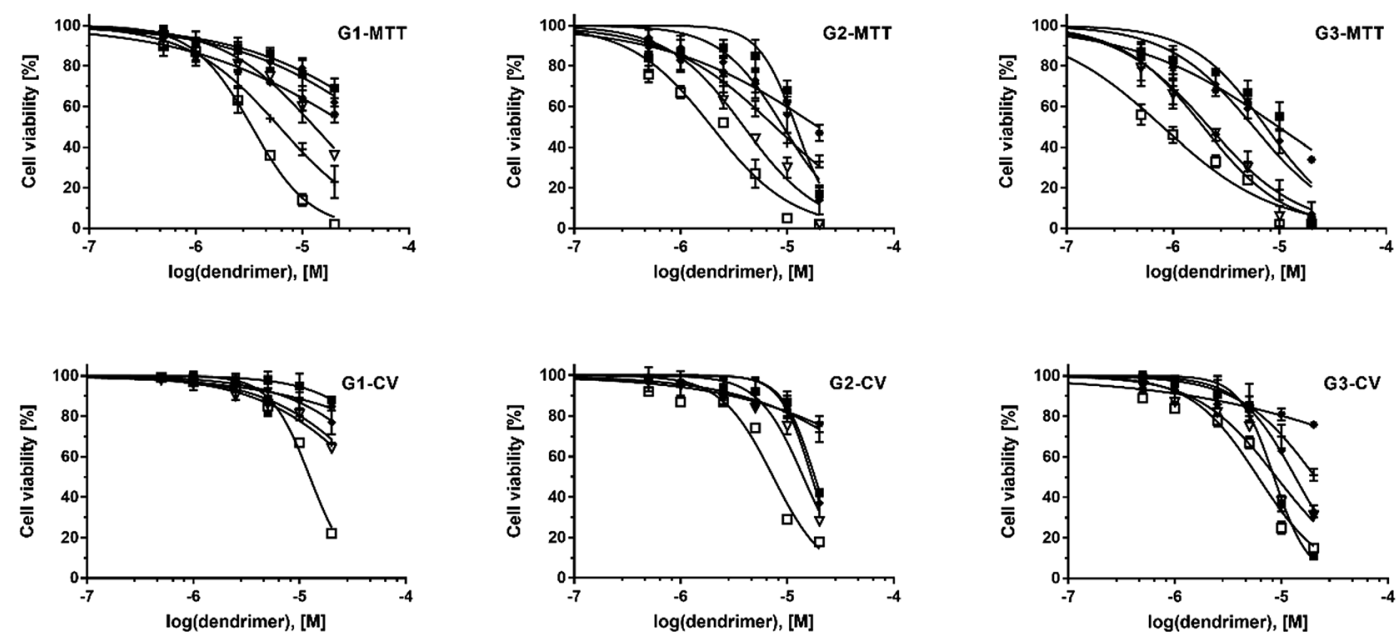

$\mathrm{NMe}_{3} \multimap \mathrm{PMe}_{3}$

七 $\mathrm{P}\left(\mathrm{Et}_{2}\right)_{2}\left(\mathrm{CH}_{2}\right)_{3} \mathrm{OH} \nabla \mathrm{PBu}_{3}$

$\mathrm{P}\left(\mathrm{C}_{6} \mathrm{H}_{4}-\mathrm{OMe}\right)_{3}+\mathrm{P}(\mathrm{Ph})_{3}$

Fig. 3 Graphical presentation of data obtained from cell viability assays. Measured data from each experimental variant were fitted with fourparameter logistic function $\left(R^{2} \geq 0.95\right)$. Each graph compares the viability of cells (B14, BRL, NRK cells) exposed to concentration gradient of different dendrimer types ( $\left.\mathrm{NMe}_{3}, \mathrm{PMe}_{3}, \mathrm{P}\left(\mathrm{Et}_{2}\right)_{2}\left(\mathrm{CH}_{2}\right)_{3} \mathrm{OH}, \mathrm{PBu}_{3}, \mathrm{P}\left(\mathrm{C}_{6} \mathrm{H}_{4}-\mathrm{OMe}\right)_{3}, \mathrm{P}(\mathrm{Ph})_{3}\right)$ of the same generation (G1-3) and measured by the same method (MTT or CV). 
Table $2 \quad \mathrm{IC}_{50}$ values of dendrimers (given in $\mu \mathrm{M}$ ) and standard error of the mean (SEM) derived from the best fit (four-parameter logistic function, $\left.R^{2} \geq 0.95\right)$ of experimental data obtained from cell viability measurements. Values are organized according to the (i) cell line used for toxicity evaluation (B14, BRL, NRK); (ii) toxicity assay method (MTT, CV); (iii) generation of dendrimer (G3, G2, G1); (iv) type of dendrimer (NMe 3 , PMe 3 , $\left.\mathrm{P}\left(\mathrm{Et}_{2}\right)_{2}\left(\mathrm{CH}_{2}\right)_{3} \mathrm{OH}, \mathrm{PBu}_{3}, \mathrm{P}\left(\mathrm{C}_{6} \mathrm{H}_{4}-\mathrm{OMe}\right)_{3}, \mathrm{P}(\mathrm{Ph})_{3}\right)$

\begin{tabular}{|c|c|c|c|c|c|c|}
\hline & $\mathrm{NMe}_{3}$ & $\mathrm{PMe}_{3}$ & $\mathrm{P}\left(\mathrm{Et}_{2}\right)_{2}\left(\mathrm{CH}_{2}\right)_{3} \mathrm{OH}$ & $\mathrm{PBu}_{3}$ & $\mathrm{P}\left(\mathrm{C}_{6} \mathrm{H}_{4}-\mathrm{OMe}\right)_{3}$ & $\mathrm{P}(\mathrm{Ph})_{3}$ \\
\hline \multicolumn{7}{|c|}{ B14-MTT } \\
\hline G3 & $2.29 \pm 0.041$ & $4.43 \pm 0.17$ & $1.64 \pm 0.11$ & $1.69 \pm 0.08$ & $6.23 \pm 0.37$ & $1.51 \pm 0.04$ \\
\hline G1 & $14.75 \pm 1.36$ & $33.18 \pm 4.08$ & $4.51 \pm 0.27$ & $5.15 \pm 0.22$ & $12.75 \pm 0.51$ & $2.50 \pm 0.24$ \\
\hline \multicolumn{7}{|c|}{ B14-CV } \\
\hline G1 & $58.7 \pm 9.07$ & $161.7 \pm 32.01$ & $153.7 \pm 29.85$ & $27.1 \pm 2.83$ & $66.7 \pm 15.91$ & $42.63 \pm 3.47$ \\
\hline \multicolumn{7}{|c|}{ BRL-MTT } \\
\hline G3 & $4.29 \pm 0.14$ & $2.54 \pm 0.15$ & $4.64 \pm 0.24$ & $1.68 \pm 0.04$ & $7.84 \pm 0.90$ & $1.59 \pm 0.08$ \\
\hline G2 & $6.06 \pm 0.17$ & $4.35 \pm 0.16$ & $5.11 \pm 0.32$ & $4.39 \pm 0.14$ & $14.69 \pm 0.99$ & $4.11 \pm 0.15$ \\
\hline G1 & $20.82 \pm 1.18$ & $15.16 \pm 0.76$ & $15.9 \pm 1.31$ & $2.34 \pm 0.54$ & $219.01 \pm 38.74$ & $19.14 \pm 1.79$ \\
\hline G1 & $81.72 \pm 20.93$ & $62.06 \pm 14.03$ & $624.5 \pm 83.75$ & $7.98 \pm 0.46$ & $1891.00 \pm 258.40$ & $13.36 \pm 0.41$ \\
\hline \multicolumn{7}{|c|}{ NRK-MTT } \\
\hline G3 & $7.41 \pm 0.89$ & $5.68 \pm 0.55$ & $0.79 \pm 0.08$ & $1.92 \pm 0.12$ & $9.68 \pm 0.67$ & $2.17 \pm 0.15$ \\
\hline $\mathrm{G} 2$ & $12.07 \pm 0.93$ & $9.15 \pm 0.76$ & $1.95 \pm 0.14$ & $3.90 \pm 0.23$ & $19.33 \pm 2.56$ & $7.67 \pm 0.48$ \\
\hline G1 & $68.45 \pm 15.13$ & $53.31 \pm 13.24$ & $3.36 \pm 0.13$ & $13.04 \pm 0.77$ & $28.47 \pm 3.65$ & $6.09 \pm 0.36$ \\
\hline \multicolumn{7}{|c|}{ NRK-CV } \\
\hline G3 & $8.48 \pm 0.25$ & $13.44 \pm 0.48$ & $6.02 \pm 0.43$ & $8.93 \pm 0.59$ & $316.3 \pm 64.12$ & $20.73 \pm 1.71$ \\
\hline G2 & $18.06 \pm 0.68$ & $16.91 \pm 0.67$ & $7.34 \pm 0.43$ & $14.08 \pm 0.72$ & $149.8 \pm 41.52$ & $86.93 \pm 8.77$ \\
\hline G1 & $106.3 \pm 24.26$ & $77.54 \pm 18.52$ & $12.47 \pm 0.35$ & $42.19 \pm 4.58$ & $335.6 \pm 83.51$ & $48.01 \pm 7.89$ \\
\hline
\end{tabular}

in case of G1 also to CV assay. Based on such observations, we may conclude that generally the cytotoxicity of $\mathrm{PMe}_{3}$ is similar or slightly lower when compared with $\mathrm{NMe}_{3}$ dendrimers based on the cell line tested. This is in agreement with the published data focused on comparative studies of phosphonium- and ammonium-modified lipid transfectants. ${ }^{32-34}$

Significant differences in comparison with all other dendrimers were shown by $\mathrm{P}\left(\mathrm{C}_{6} \mathrm{H}_{4}-\mathrm{OMe}\right)_{3}$ dendrimer 25-27. In fact, it's very low cytotoxicity was measured across all cell lines, assay methods used and generations (except some small differences of $\mathrm{G} 1$ on B14 cells). $\mathrm{IC}_{50}$ calculated for MTT assay were in the range of 6-219 $\mu \mathrm{M}$, whereas for $\mathrm{CV}$ assay those values were shifted up to $66-1890 \mu \mathrm{M}$ (based on the cell line and dendrimer generation). This exceptionally low cytotoxicity as compared to other dendrimer types in this study falls in the range reported for sugar or even PEG coated dendrimers. ${ }^{7,13,45}$ For example, Janaszewska et al. ${ }^{\mathbf{4}}$ reported the $\mathrm{IC}_{50}$ value of maltose-modified open shell and dense shell poly(propylene imine) (PPI) dendrimers between 100-145 $\mu \mathrm{M}$ when studied on SKOV3 cell line, contrary to unmodified cationic PPI dendrimers with $\mathrm{IC}_{50}<8$ $\mu \mathrm{M}$. Similarly, Wrobel et al. ${ }^{13}$ showed the significant haemolytic activity of maltose functionalized hyperbranched poly(ethylene imine)s starting at 100-300 $\mu \mathrm{M}$ concentration depending on density of maltose units on PEI polymer. It is not so straightforward to explain such exceptional properties of $\mathrm{P}\left(\mathrm{C}_{6} \mathrm{H}_{4}-\mathrm{OMe}\right)_{3}$ dendrimer. We may hypothesize that it's relatively low cytotoxicity may be possibly related to delocalization of positive charge on phosphorus atoms caused by three electron-donating methoxy groups in para positions capable of conjugation with electrons of aromatic rings and with the phosphonium center. The delocalization of positive charge of outer shell together with larger concentration of charged groups in the interior of dendrimer, caused by significant backfolding of dendrimer branches (as discussed in chapter 3.2) could decrease the toxic interactions with the cell membrane and proteins in cytoplasmic space. Because still being positively charged and therefore able to complex siRNA we suggest that this type of dendrimer could be an interesting alternative to low-toxic pegylated or sugar coated dendrimers for receptor targeted siRNA delivery in vivo.

Interestingly, recognizable large differences in cell viability as measured by MTT and CV assay were in several cases, along with $\mathrm{P}\left(\mathrm{C}_{6} \mathrm{H}_{4}-\mathrm{OMe}\right)_{3}$ dendrimer, also observed for $\mathrm{P}(\mathrm{Ph})_{3}$ dendrimer (31-33). This dendrimer is quite toxic when measured by MTT $\left(\mathrm{IC}_{50}<2.5 \mu \mathrm{M}\right.$ at G3). On the contrary, the toxicity measured by $\mathrm{CV}$ was in some cases (e.g. B14 G3, NRK G2) significantly lower $\left(\mathrm{IC}_{50}>19 \mu \mathrm{M}\right.$ for B14-G3 and $86 \mu \mathrm{M}$ for NRKG2) when compared with other types of dendrimers ranking it second (after $\mathrm{P}\left(\mathrm{C}_{6} \mathrm{H}_{4} \text {-OMe }\right)_{3}$ dendrimer) in line (decreasing order of toxicity, see e.g. Fig. 4, B14-CV-G3). Such results are 

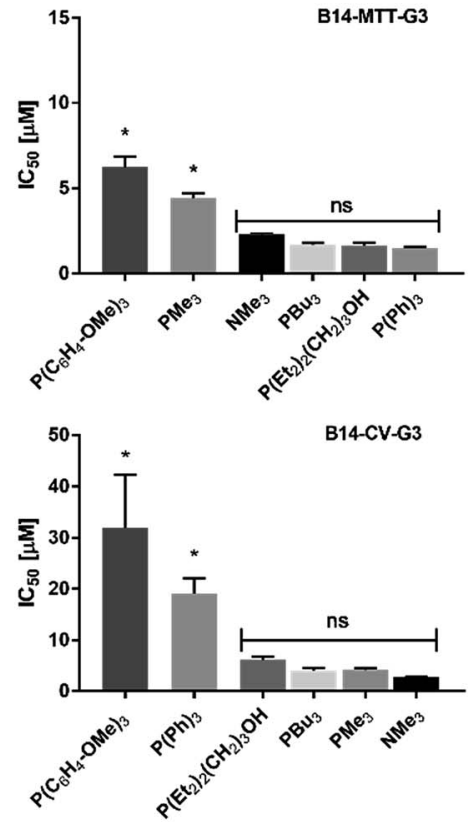
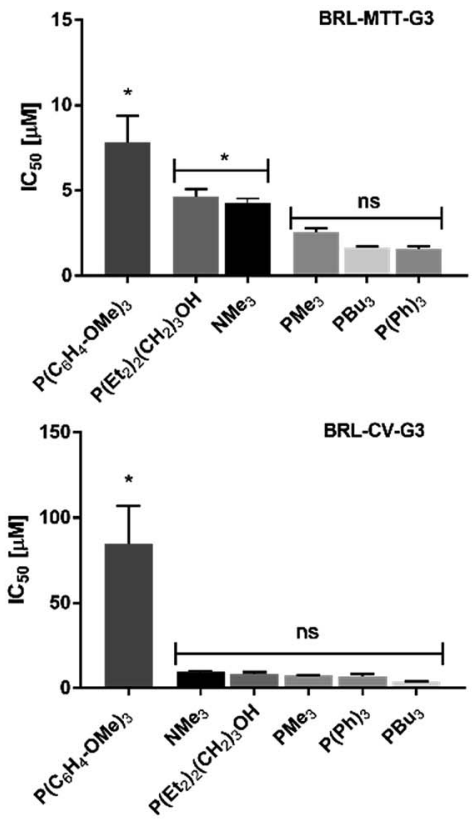
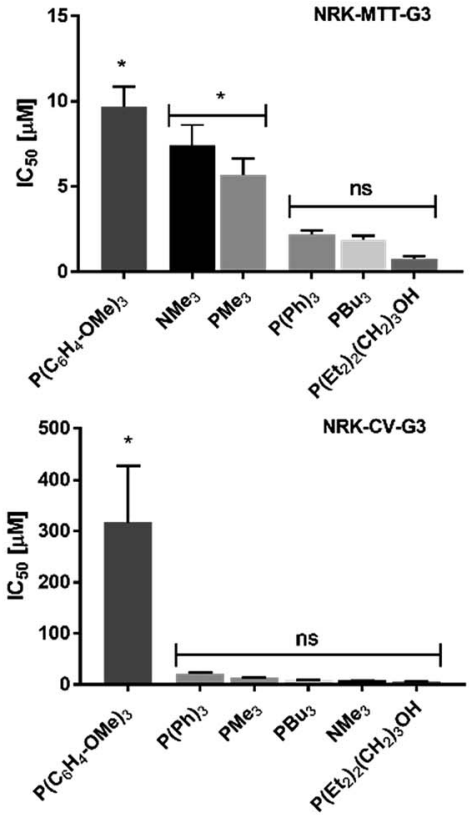

\section{Comparison of $\mathrm{IC}_{50}$ obtained by MTT and CV method (G3)}
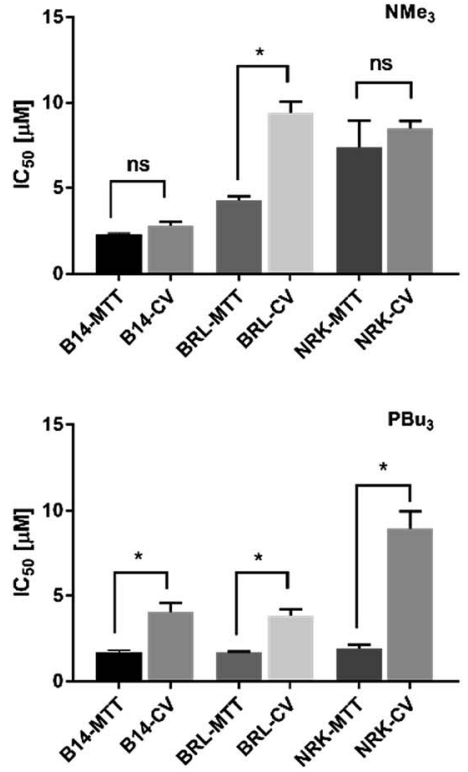
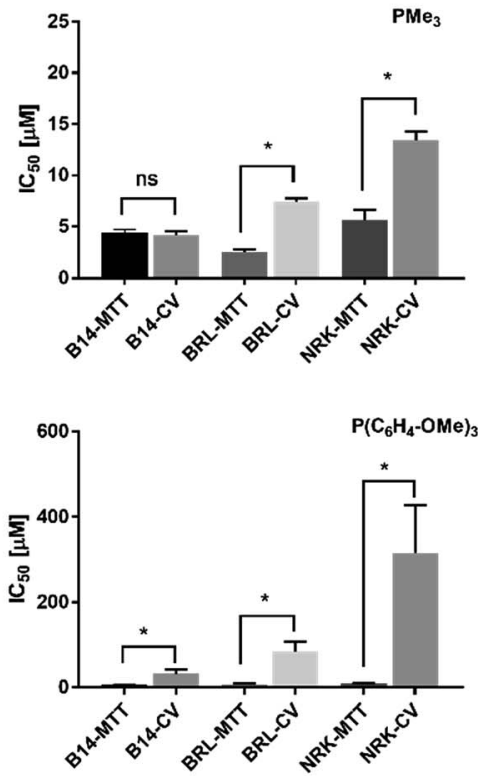
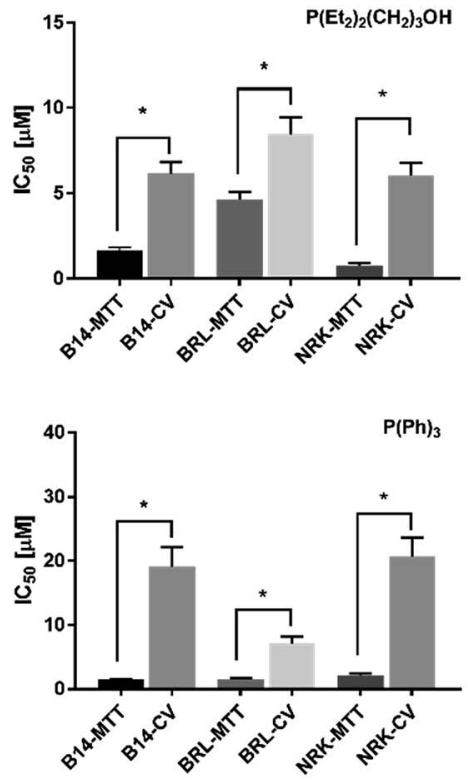

Fig. 4 Evaluation of $\mathrm{G} 3$ dendrimers cytotoxicity based on $\mathrm{IC}_{50}$ values. Upper panel: To evaluate and rank cytotoxic effect of each kind of dendrimer based on comparison of $\mathrm{IC}_{50}$ values summarized in Table 2, data of $\mathrm{IC}_{50}$ of all dendrimer types were plotted in a common column graph for each cell line (B14, BRL, NRK) and assay method used (MTT, CV). Each dendrimer (column) is placed in the order of decreasing mean value of $\mathrm{IC}_{50}$ (from left to right, increasing toxicity). With the aim to determine a statistical significance of difference between the $\mathrm{IC}_{50}$ values of all dendrimers, one-way ANOVA followed with Tukey-Kramer multiply comparison test was used to quantify the $p$ values between each dendrimer. Values $p<0.05$ were supposed to be statistically significant $(*)$, values $p \geq 0.05$ non-significant (ns). Columns were grouped in the graph based on their $p$ values as compared to lowest $I C_{50}$ mean value present and $p$ values related to their nearest neighbour. Statistical difference between the grouped dendrimers is therefore $p \geq 0.05$ (ns), whereas between groups is $p<0.05(*)$. In this way, a relative order of dendrimer toxicity was constructed for each cell line and assay method used. Data are presented as mean $\pm \operatorname{SEM}(n=3)$. Lower panel: To compare the difference between the toxicity of G3 dendrimers measured by MTT and CV methods, a set of graphs representing $\mathrm{IC}_{50}$ values of the same dendrimer assayed by both methods on different cell lines were constructed. To determine a statistical significance of difference between the IC $C_{50}$ values measured by MTT and CV method for one cell line, unpaired $t$-test was used to quantify the $p$ values. Values $p<0.05$ were supposed to be statistically significant $(*)$, values $p \geq 0.05$ non-significant $(n s)$. Data are presented as mean $\pm \operatorname{SEM}(n=3)$. 
quite interesting taking in mind a relatively high hydrophobicity of phenyl groups. Moreover, lower toxic influence on the growth of cells as observed in some cases and relatively high toxicity observed by MTT suggests possible preferential targeting of this dendrimer into mitochondria. This, in fact, supports the previously published results on triphenylphosphonium (TPP) modified PAMAM dendrimers. ${ }^{37}$ Fluorescently labeled PAMAM dendrimers, surface functionalized with TPP were selectively targeted into the mitochondria and showed a decreased overall toxicity to cells as compared to unmodified

\section{Effect of dendrimer generation on cytoxicity based on IC (M0 $_{\text {(MT assay) }}$}
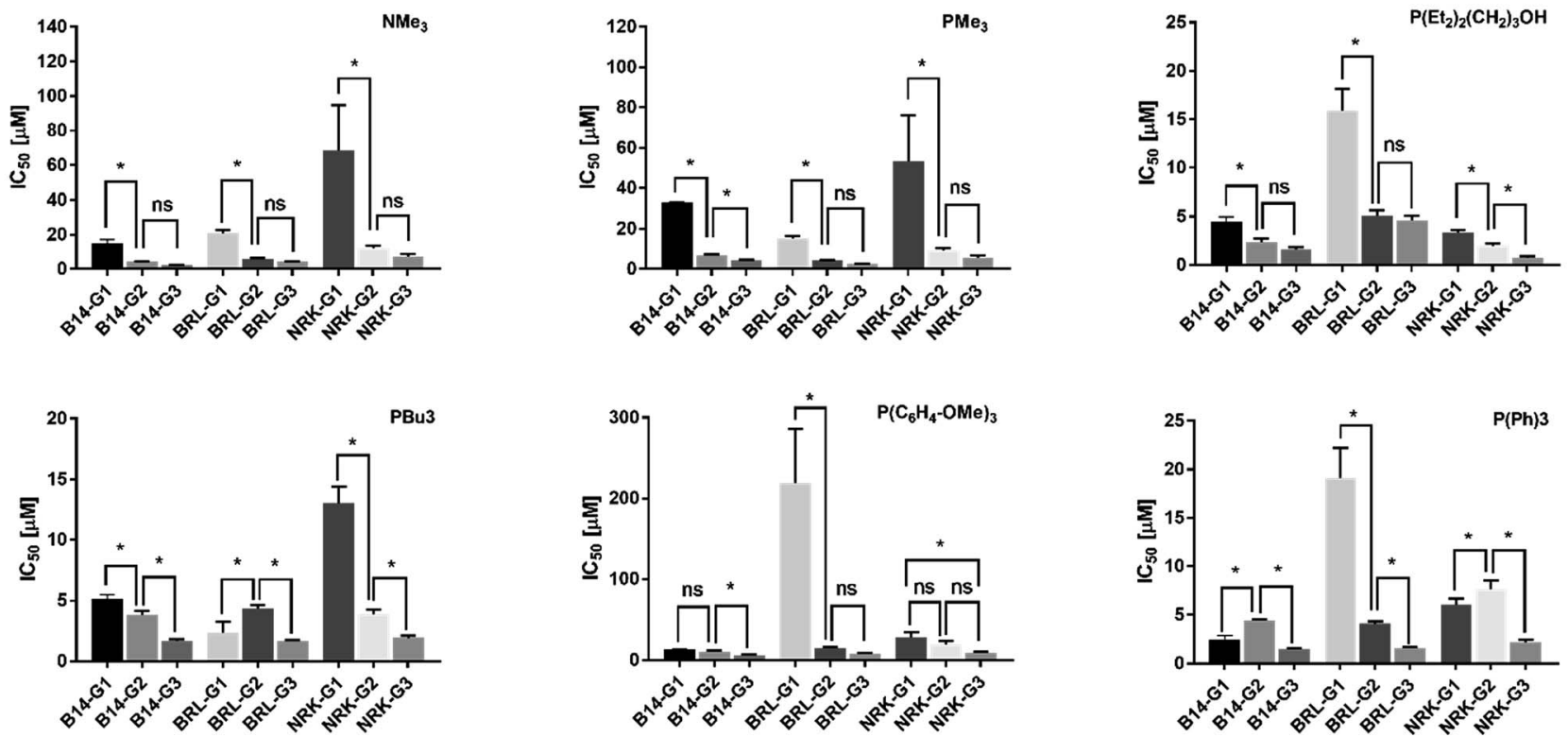

\section{Effect of dendrimer generation on cytoxicity based on $\mathrm{IC}_{50}$ (CV assay)}
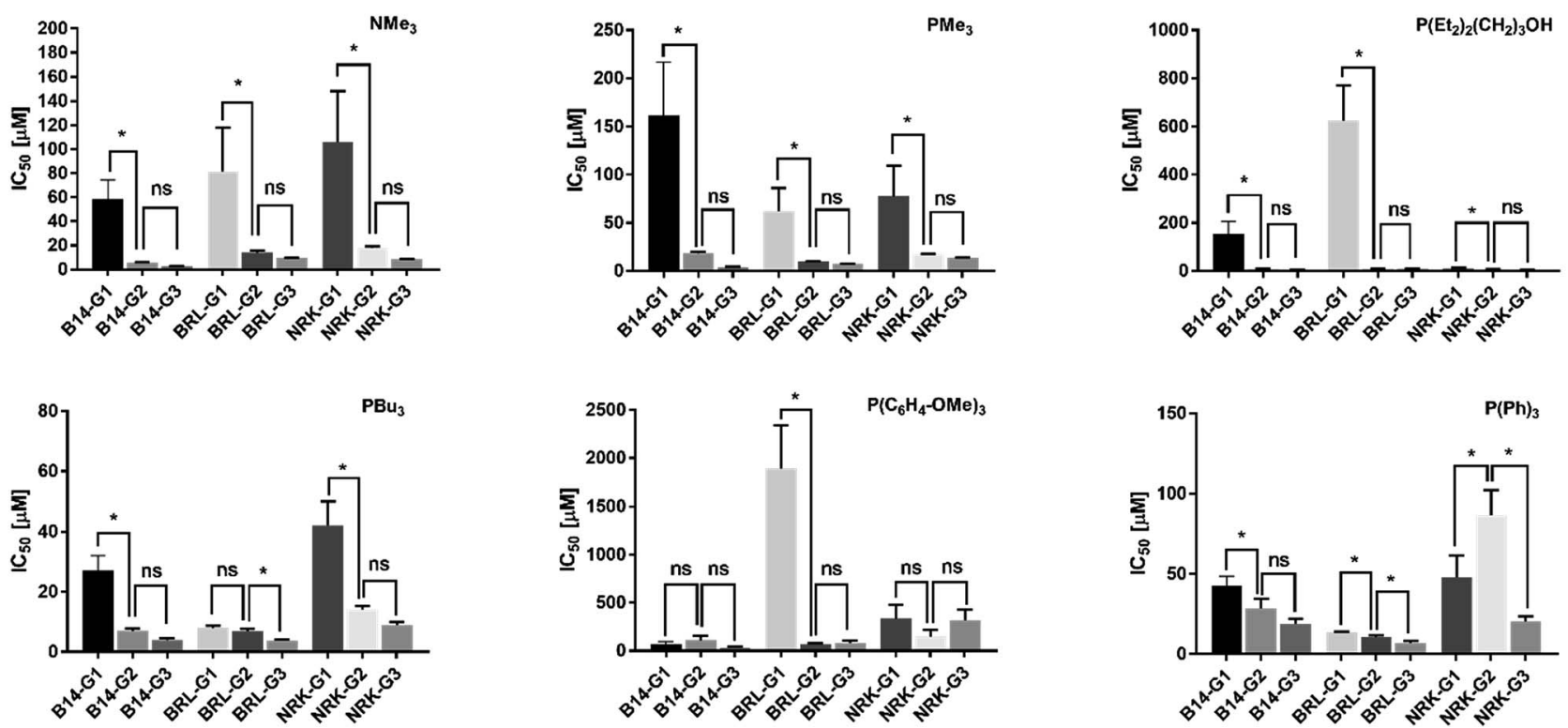

Fig. 5 Effect of dendrimer generation on cytotoxicity based on $I_{50}$. Upper panel: Data obtained by MTT assay. Lower panel: Data obtained by CV assay. Each graph represents data analyzed for one type of dendrimer and for three generations (G1-G3) grouped and compared each to other for each cell line. To determine a statistical significance of difference between the $\mathrm{IC}_{50}$ values of all three generations of dendrimers on one cell line, one-way ANOVA followed with Tukey-Kramer multiply comparison test was used to quantify the $p$ values between each generation. Values $p<0.05$ were supposed to be statistically significant $(*)$, values $p \geq 0.05$ non-significant (ns). Data are presented as mean $\pm \operatorname{SEM}$ ( $n=3$ ). 
dendrimer. In fact, it is well known that triphenylphosphonium (TPP), a cation with sufficient lipophilicity and delocalized positive charge, is an efficient mitochondriotropic ligand which promotes accumulation of various TPP conjugated molecules in the mitochondria. ${ }^{47}$ Thus, despite having no direct evidence, we suggest that $\mathrm{P}\left(\mathrm{C}_{6} \mathrm{H}_{4}-\mathrm{OMe}\right)_{3}$ and $\mathrm{P}(\mathrm{Ph})_{3}$ dendrimers may preferentially accumulate in mitochondria causing relatively large differences in toxicity as observed by MTT and CV assay. If this holds true than those two dendrimers could represent a unique drug delivery systems (DDSs) for mitochondrial targeting with relatively low toxicity as compared to other types of comparable systems. Such hypothesis will be verified by further investigations.

The last group of dendrimers which are characterized by quite similar cytotoxic effects are $\mathrm{PBu}_{3}$ and $\mathrm{P}\left(\mathrm{Et}_{2}\right)_{2}\left(\mathrm{CH}_{2}\right)_{3} \mathrm{OH}$ dendrimers (19-21, 13-15). Both are ranked among the most cytotoxic dendrimers in both - MTT and CV assays (see Table 2) with some exception of $\mathrm{P}\left(\mathrm{Et}_{2}\right)_{2}\left(\mathrm{CH}_{2}\right)_{3} \mathrm{OH}$ observed at $\mathrm{G} 1$ (B14, $\mathrm{BRL}-\mathrm{CV}$ assay). The reason for the higher cytotoxicity observed could be the presence of hydrophobic alkyl substituents on phosphonium groups. Interestingly, there is no significant positive effect of - $\mathrm{OH}$ groups present on $\mathrm{P}\left(\mathrm{Et}_{2}\right)_{2}\left(\mathrm{CH}_{2}\right)_{3} \mathrm{OH}$ dendrimer on decreasing of cytotoxic effect.

Based on these results, we may conclude that the replacement of methyl substituents on phosphonium group with more hydrophobic and bulky alkyl groups $\left(\mathrm{P}\left(\mathrm{Et}_{2}\right)_{2}\left(\mathrm{CH}_{2}\right)_{3} \mathrm{OH}, \mathrm{PBu}_{3}\right)$ leads to the increase of overall cytotoxicity towards the mitochondria and strong inhibition of cell growth. Substitution of methyl substituents with phenyl and $p$-tolyl groups leads to significant differences in toxicity as observed by MTT and CV method, with higher observed toxicity of dendrimers towards the mitochondria. This effect is extremely pronounced in the case of $\mathrm{P}\left(\mathrm{C}_{6} \mathrm{H}_{4}-\mathrm{OMe}\right)_{3}$ dendrimers which are more than order of magnitude less toxic when measured by $\mathrm{CV}$ method as compared to MTT. Such effects are more visible at higher (G2, G3) generations of dendrimers, where the larger amount of phosphonium groups on dendrimer is present. Similar results were demonstrated by Ornelas-Megiatto et $a l .{ }^{30}$ in their study of cytotoxicity of alkyl-functionalized polyphosphonium polymers. The nature of the alkyl substituents of the phosphonium cations was also shown to have important influence on the transfection efficiency where the phosphonium groups of the analogous composition as ammonium ones achieved a much better transfection efficiency and lower cytotoxicity. Therefore, we expect that a similar positive effect could be observed with phosphonium carbosilane dendrimers in dependence on the type of substituent used.

2.3.2 Influence of dendrimer generation on cytotoxicity. Dendrimer generation is another important parameter, which influence their overall cytotoxicity. As is apparent from Fig. 5, dendrimer cytotoxicity significantly increases between G1 to G2 generation regardless on assay method and cell line used. On the contrary, much smaller differences were observed between G2 and G3 dendrimers. The differences between $\mathrm{IC}_{50}$ of G2 and G3 were statistically significant only in few cases (see Fig. 5). The toxicity of dendrimer is always a function of toxicity of core and outer shell. First generation dendrimers, where a hydrophobic core is more open and the number of ammonium/ phosphonium groups is low are much less toxic than G2 and G3 dendrimers where the number of positively charged groups increases and creates an outer shell of dendrimer. Thus, the contribution of hydrophobic core to overall cytotoxicity of dendrimers is negligible.

2.3.3 Influence of assay method. MTT and CV assay were selected for cytotoxicity screening since they measure the effect of compound (dendrimer) based on different principles. The MTT is related to specific enzymatic activity connected with mitochondria, CV monitors the growth of cell population. As is apparent from Fig. 4, S70 and S71, $\uparrow$ MTT assay is more sensitive to presence of dendrimer than $\mathrm{CV}$ assay. Statistically significant differences in $\mathrm{IC}_{50}$ of MTT and CV $\left(\mathrm{IC}_{50}\right.$ MTT $\left.<\mathrm{IC}_{50} \mathrm{CV}\right)$ were observed in the most of the experimental variations regardless on dendrimer type, generation and cell line. Moderate differences between $\mathrm{IC}_{50}$ of MTT and CV (differences within an order of magnitude) were present mainly in case of $\mathrm{NMe}_{3}, \mathrm{PMe}_{3}$, $\mathrm{P}\left(\mathrm{Et}_{2}\right)_{2}\left(\mathrm{CH}_{2}\right)_{3} \mathrm{OH}$ and $\mathrm{PBu}_{3}$ dendrimers. Contrary to this, much higher differences $\left(\mathrm{IC}_{50} \mathrm{MTT} \ll \mathrm{IC}_{50} \mathrm{CV}\right)$ were apparent in case of $\mathrm{P}\left(\mathrm{C}_{6} \mathrm{H}_{4}-\mathrm{OMe}\right)_{3}$ and $\mathrm{P}(\mathrm{Ph})_{3}$ dendrimers as was already discussed above. Similar discrepancies between the $\mathrm{IC}_{50}$ of various inhibitors measured by MTT and CV method have been already discussed elsewhere. ${ }^{48}$ The reason of such observations could be the preferential interaction of toxic compound with mitochondrial metabolism or provoking a cell stress which onset is faster than reduction of cell population growth by necrosis or apoptosis. ${ }^{48,49}$ Higher differences observed in case of $\mathrm{P}\left(\mathrm{C}_{6} \mathrm{H}_{4}\right.$ $\mathrm{OMe})_{3}$ and $\mathrm{P}(\mathrm{Ph})_{3}$ dendrimers could be connected to their preferential targeting and therefore also higher influence on the metabolism of mitochondria, as suggested from other published works. ${ }^{37}$ Our experiments also support the conclusions discussed elsewhere ${ }^{\mathbf{4 8}}$ that to evaluate reliably the cytotoxicity of novel types of nanoparticles, several assay methods must be performed simultaneously, since they can give a different or sometimes even misleading results.

\section{Conclusions}

The carbosilane dendrimers with $\mathrm{NMe}_{3}, \mathrm{PMe}_{3}, \mathrm{P}\left(\mathrm{Et}_{2}\right)_{2}\left(\mathrm{CH}_{2}\right)_{3}$ $\mathrm{OH}, \mathrm{PBu}_{3}, \mathrm{P}\left(\mathrm{C}_{6} \mathrm{H}_{4}-\mathrm{OMe}\right)_{3}$ and $\mathrm{P}(\mathrm{Ph})_{3}$ periphery substituents were synthesized, thoroughly characterized and simulated by computer modelling approaches. Dendrimers containing butyl, methoxyphenyl and phenyl substituents showed only negligible solubility in water when the counter-anion was the iodide ion. By exchange of the iodide anions for chloride using ion exchange resign the solubility in water was considerably increased to $>100 \mathrm{mg} \mathrm{mL}^{-1}$.

Computer simulations show that higher generation dendrimers maintain spherical shape and their dimensions are comparable with only negligible differences. Radial distribution function revealed interesting properties of $\mathrm{P}\left(\mathrm{C}_{6} \mathrm{H}_{4}-\mathrm{OMe}\right)_{3}$ dendrimer with apparent backfolding of peripheral groups and the smallest water density in the interior of dendrimer in comparison with other dendrimer types.

Generally, the cytotoxicity of $\mathrm{PMe}_{3}$ carbosilane dendrimers was similar or slightly lower as compared to $\mathrm{NMe}_{3}$ dendrimers which 
correlates well with the published works focused on phosphonium- and ammonium-modified lipid transfectants. ${ }^{32-34}$ The substitution of methyl groups of $\mathrm{PMe}_{3}$ carbosilane dendrimers with more hydrophobic and bulky alkyl substituents $\left(\mathrm{PBu}_{3}\right.$ and $\mathrm{P}\left(\mathrm{Et}_{2}\right)_{2}\left(\mathrm{CH}_{2}\right)_{3} \mathrm{OH}$ dendrimers $)$ resulted in increase of cytotoxicity as measured by MTT and CV method regardless of cell line tested. Significant differences in comparison with all other dendrimers were shown for $\mathrm{P}\left(\mathrm{C}_{6} \mathrm{H}_{4}-\mathrm{OMe}\right)_{3}$ dendrimer and partially also in the case of $\mathrm{P}(\mathrm{Ph})_{3}$ dendrimer. $\mathrm{P}\left(\mathrm{C}_{6} \mathrm{H}_{4}-\mathrm{OMe}\right)_{3}$ dendrimer is of very low cytotoxicity across all cell lines or assay methods used and can be even compared to low cytotoxic sugar or PEG coated dendrimers. ${ }^{7,13,45}$ Recognizably large differences in cell viability as was measured by MTT and CV assay were in several cases, along with $\mathrm{P}\left(\mathrm{C}_{6} \mathrm{H}_{4}-\mathrm{OMe}\right)_{3}$ dendrimer, observed also for $\mathrm{P}(\mathrm{Ph})_{3}$ dendrimer. Based on such observations, we suggest that $\mathrm{P}\left(\mathrm{C}_{6} \mathrm{H}_{4}-\mathrm{OMe}\right)_{3}$ and $\mathrm{P}(\mathrm{Ph})_{3}$ dendrimers may preferentially accumulate in mitochondria. Therefore, both dendrimers could represent unique drug delivery systems (DDS) for mitochondrial targeting with relatively low cytotoxicity as compared to other types of DDS systems.

\section{Experimental section}

\subsection{General considerations}

Unless otherwise stated, reagents were used as received from commercial sources. Literature procedures were followed in the preparation of (3 chloropropyl)dimethylsilane ${ }^{50}$ and allylterminated carbosilane dendrimers. ${ }^{51}$ Karstedt catalyst (obtained as a $2-3 \%$ solution in xylenes), trimethylphosphine (1.0 M solution in THF), triphenylphosphine and AMBERLYST A-21 were purchased from Sigma Aldrich, trimethylamine ( $c a$. $25 \%$ solution in isopropyl alcohol), tris( $p$-methoxyphenyl) phosphine and tributylphosphine from TCI chemicals. Diethyl(3-hydroxypropyl)-phosphine was taken from laboratory supplies. The ${ }^{1} \mathrm{H}$ (299.9 or $499.9 \mathrm{MHz}$ ), ${ }^{13} \mathrm{C}\left\{{ }^{1} \mathrm{H}\right\}$ (75.4 or 125.7 $\mathrm{MHz}$ ) and ${ }^{29} \mathrm{Si}\left\{{ }^{1} \mathrm{H}\right\}$ (59.6 or 99.3 MHz), ${ }^{31} \mathrm{P}\left\{{ }^{1} \mathrm{H}\right\}$ (121.4 or 202.4 $\mathrm{MHz}$ ) NMR spectra were measured on a Varian Mercury 300 or Varian Innova 500 spectrometer at $25{ }^{\circ} \mathrm{C}$. The ${ }^{1} \mathrm{H}$ and ${ }^{13} \mathrm{C}$ NMR spectra were referenced to the line of the solvent $\left(\delta / \mathrm{ppm} ; \delta_{\mathrm{H}} / \delta_{\mathrm{C}}\right.$ : $\mathrm{CDCl}_{3}, 7.26 / 76.99 ;$ DMSO- $\left.d_{6}, 2.51 / 39.52 ; \mathrm{CD}_{3} \mathrm{CN}, 1.94 / 1.32\right)$. The

${ }^{29} \mathrm{Si}$ and ${ }^{31} \mathrm{P}$ NMR spectra were referenced to external standards.

HRMS spectra were measured using Bruker MicrOTOF-QIII apparatus. Due to the structure of target compounds, the electrospray ionisation source in positive mode was used with the parameters adjusted as follows: the capillary voltage was $4200 \mathrm{~V}$, the end plate offset was $-500 \mathrm{~V}$. The collision cell RF ranged from $350 \mathrm{Vpp}$ to $1000 \mathrm{Vpp}$, based on the size of the measured molecule. Nitrogen was used as the nebulizer gas (at the pressure of 1.6 bar), just as the drying gas (heated to $180{ }^{\circ} \mathrm{C}$, with the flow of $8 \mathrm{~L} \mathrm{~min}{ }^{-1}$ ). The scans of MS spectra were carried out in the mass range of $\mathrm{m} / \mathrm{z}$ 80-1550 for the smaller and 200-6000 for the bigger dendrimers. For HRMS, the calibration on Naformate or CsPFHA clusters was employed. To support ionisation in solutions of uncharged dendrimers, ammonium formate buffer (5 mL MeOH, $1.25 \mathrm{~mL} \mathrm{HCOOH,} 3.9 \mathrm{~g}$ $\mathrm{HCOO}^{-} \mathrm{NH}_{4}{ }^{+}$, filled up to $25 \mathrm{~mL}$ with water) was used. The samples were delivered into the ESI source by direct infusion, using a syringe pump (Kd-Scientific, KDS-100-CE, 0.5 mL
Hamilton syringe, flow $180 \mathrm{~mL} \min ^{-1}$ ) coupled to the MicrOTOF-QIII mass spectrometer.

\subsection{Synthesis of dendrimers}

4.2.1 Dendrimer (1). Two drops of Karstedt catalyst solution were added to a solution of tetraallylsilane $(1.00 \mathrm{~g}, 5.2$ $\mathrm{mmol})$ in pentane $(2 \mathrm{~mL})$. After the mixture was stirred for $10 \mathrm{~min}$, (3-chloropropyl)dimethylsilane (2.91 g, $21.3 \mathrm{mmol}$ ) was added and the mixture was refluxed for $3 \mathrm{~h}$ and then stirred at room temperature overnight. The solvent and the excess of silane were removed on the rotary evaporator and finally under high vacuum. Yield: $3.80 \mathrm{~g}$ (5.15 mmol, 99\%) of dendrimer 1 as colourless liquid. Data for 1: NMR $\left(\mathrm{CDCl}_{3}\right)$ : ${ }^{1} \mathrm{H}(499.99 \mathrm{MHz})$ : $\delta-0.02\left(\mathrm{~s}, 24 \mathrm{H}, \mathrm{Si}^{1} \mathrm{CH}_{3}\right), 0.54-0.61\left(\mathrm{~m}, 24 \mathrm{H}, \mathrm{Si}^{0} \mathrm{CH}_{2}, \mathrm{CH}_{2^{-}}\right.$ $\mathrm{Si}^{1} \mathrm{CH}_{2}$ ), 1.28-1.35 (m, 8H, $\left.\mathrm{Si}^{0} \mathrm{CH}_{2} \mathrm{CH}_{2}\right), 1.72-1.78\left(\mathrm{~m}, 8 \mathrm{H}, \mathrm{CH}_{2}-\right.$ $\left.\mathrm{CH}_{2} \mathrm{Cl}\right), 3.50\left(\mathrm{t},{ }^{3} \mathrm{~J}_{\mathrm{HH}}=7.0 \mathrm{~Hz}, 8 \mathrm{H}, \mathrm{CH}_{2} \mathrm{Cl}\right) .{ }^{13} \mathrm{C}\left\{{ }^{1} \mathrm{H}\right\}(125.70$ $\mathrm{MHz}): \delta-3.4\left(\mathrm{Si}^{1} \mathrm{CH}_{3}\right), 13.0\left(\mathrm{CH}_{2} \mathrm{CH}_{2} \mathrm{CH}_{2} \mathrm{Cl}\right), 17.5\left(\mathrm{Si}^{0} \mathrm{CH}_{2}\right), 18.5$ $\left(\mathrm{Si}^{0} \mathrm{CH}_{2} \mathrm{CH}_{2}\right), 20.1\left(\mathrm{Si}^{0} \mathrm{CH}_{2} \mathrm{CH}_{2} \mathrm{CH}_{2}\right), 27.7\left(\mathrm{CH}_{2} \mathrm{CH}_{2} \mathrm{Cl}\right), 48.0$ $\left(\mathrm{CH}_{2} \mathrm{Cl}\right) .{ }^{29} \mathrm{Si}\left\{{ }^{1} \mathrm{H}\right\}(59.60 \mathrm{MHz}): \delta 0.58\left(\mathrm{Si}^{0}\right), 2.05\left(\mathrm{Si}^{1}\right)$. HRMS $\left(\mathrm{C}_{32} \mathrm{H}_{72} \mathrm{Cl}_{4} \mathrm{Si}_{5}\right):\left(\mathrm{ESI}^{+}\right) \mathrm{m} / \mathrm{z}:\left[\mathrm{M}+\mathrm{NH}_{4}\right]^{+}$calcd for $\mathrm{C}_{32} \mathrm{H}_{72} \mathrm{Cl}_{4} \mathrm{Si}_{5^{-}}$ $\mathrm{NH}_{4}$ : 756.3551 found: $756.3559,[\mathrm{M}+\mathrm{Na}]^{+}$calcd for $\mathrm{C}_{32} \mathrm{H}_{72} \mathrm{Cl}_{4^{-}}$ $\mathrm{Si}_{5} \mathrm{Na}$ : 761.3104, found: 761.3104 .

4.2.2 Dendrimer (2). The compound was synthesized according to the procedure for 1 from $\mathrm{G}_{1} \operatorname{allyl}_{8}(1.3 \mathrm{~g}, 1.86 \mathrm{mmol})$ and (3-chloropropyl)dimethylsilane (2.24 g, $16.4 \mathrm{mmol})$. Yield: $3.30 \mathrm{~g}$ (1.84 mmol, 99\%) of a yellow oil. Data for 2: $\mathrm{NMR}\left(\mathrm{CDCl}_{3}\right)$ : ${ }^{1} \mathrm{H}(499.99 \mathrm{MHz}): \delta-0.07\left(\mathrm{~s}, 12 \mathrm{H}, \mathrm{Si}^{1} \mathrm{CH}_{3}\right),-0.02(\mathrm{~s}, 48 \mathrm{H}$, $\mathrm{Si}^{2} \mathrm{CH}_{3}$ ), 0.53-0.60 (m, 64H, $\mathrm{Si}^{0} \mathrm{CH}_{2}, \mathrm{CH}_{2} \mathrm{Si}^{1} \mathrm{CH}_{2}, \mathrm{CH}_{2} \mathrm{Si}^{2} \mathrm{CH}_{2}$ ), 1.28-1.34 (m, 24H, $\left.\mathrm{CH}_{2} \mathrm{CH}_{2} \mathrm{Si}^{1} \mathrm{CH}_{2} \mathrm{CH}_{2}\right), 1.72-1.78(\mathrm{~m}, 16 \mathrm{H}$, $\left.\mathrm{CH}_{2} \mathrm{CH}_{2} \mathrm{Cl}\right), 3.50\left(\mathrm{t},{ }^{3} J_{\mathrm{HH}}=7.0 \mathrm{~Hz}, 16 \mathrm{H}, \mathrm{ClCH}_{2}\right) .{ }^{13} \mathrm{C}\left\{{ }^{1} \mathrm{H}\right\}(125.70$ $\mathrm{MHz}): \delta-5.0\left(\mathrm{Si}^{1} \mathrm{CH}_{3}\right),-3.4\left(\mathrm{Si}^{2} \mathrm{CH}_{3}\right), 13.0\left(\mathrm{CH}_{2} \mathrm{CH}_{2} \mathrm{CH}_{2} \mathrm{Cl}\right), 17.7$ $\left(\mathrm{Si}^{0} \mathrm{CH}_{2}\right), \quad 18.4\left(\mathrm{Si}^{1} \mathrm{CH}_{2} \mathrm{CH}_{2} \mathrm{CH}_{2} \mathrm{Si}^{2}\right), 18.6\left(\mathrm{Si}^{0} \mathrm{CH}_{2} \mathrm{CH}_{2}\right), 18.8$ $\left(\mathrm{Si}^{1} \mathrm{CH}_{2} \mathrm{CH}_{2} \mathrm{CH}_{2} \mathrm{Si}^{2}\right), 19.2\left(\mathrm{Si}^{0} \mathrm{CH}_{2} \mathrm{CH}_{2} \mathrm{CH}_{2}\right), 19.9\left(\mathrm{Si}^{1} \mathrm{CH}_{2} \mathrm{CH}_{2}-\right.$ $\left.\mathrm{CH}_{2} \mathrm{Si}^{2}\right), 27.7\left(\mathrm{CH}_{2} \mathrm{CH}_{2} \mathrm{CH}_{2} \mathrm{Cl}\right), 48.0\left(\mathrm{CH}_{2} \mathrm{Cl}\right) .{ }^{29} \mathrm{Si}\left\{{ }^{1} \mathrm{H}\right\}(59.60$ $\mathrm{MHz}): \delta 0.49\left(\mathrm{Si}^{0}\right), 0.97\left(\mathrm{Si}^{1}\right) ; 2.06\left(\mathrm{Si}^{2}\right)$. HRMS $\left(\mathrm{C}_{80} \mathrm{H}_{180} \mathrm{Cl}_{8} \mathrm{Si}_{13}\right)$ : $\left(\mathrm{ESI}^{+}\right) \mathrm{m} / z:\left[\mathrm{M}+\mathrm{NH}_{4}\right]^{+}$calcd for $\mathrm{C}_{80} \mathrm{H}_{180} \mathrm{Cl}_{8} \mathrm{Si}_{13} \mathrm{NH}_{4}: 1808.8888$ found: 1808.8838 .

4.2.3 Dendrimer (3). The compound was synthesized according to the procedure for 1 from $\mathrm{G}_{2} \operatorname{allyl}_{16}(1.5 \mathrm{~g}, 0.88 \mathrm{mmol})$ and (3-chloropropyl)dimethylsilane (2.11 g, $15.46 \mathrm{mmol})$. Yield: $3.36 \mathrm{~g}(0.87 \mathrm{mmol}, 99 \%)$ of a yellow oil. Data for 3: $\mathrm{NMR}\left(\mathrm{CDCl}_{3}\right)$ : ${ }^{1} \mathrm{H}$ (499.99 MHz): $\delta-0.08$ (s, 36H, Si $\left.{ }^{1,2} \mathrm{CH}_{3}\right),-0.02\left(\mathrm{~s}, 96 \mathrm{H}, \mathrm{Si}^{3} \mathrm{CH}_{3}\right)$, 0.53-0.60 (m, $144 \mathrm{H}, \mathrm{Si}^{0} \mathrm{CH}_{2}, \mathrm{CH}_{2} \mathrm{Si}^{1} \mathrm{CH}_{2}, \mathrm{CH}_{2} \mathrm{Si}^{2} \mathrm{CH}_{2}, \mathrm{CH}_{2} \mathrm{Si}^{3} \mathrm{CH}_{2}$ ), 1.28-1.33 (m, 56H, $\mathrm{CH}_{2} \mathrm{CH}_{2} \mathrm{Si}^{1} \mathrm{CH}_{2} \mathrm{CH}_{2} \mathrm{CH}_{2} \mathrm{Si}^{2} \mathrm{CH}_{2} \mathrm{CH}_{2}$ ), 1.71-1.7 $\left(\mathrm{m}, 32 \mathrm{H}, \mathrm{CH}_{2} \mathrm{CH}_{2} \mathrm{Cl}\right), 3.49\left(\mathrm{t},{ }^{3} J_{\mathrm{HH}}=7.0 \mathrm{~Hz}, 32 \mathrm{H}, \mathrm{ClCH}_{2}\right) .{ }^{13} \mathrm{C}\left\{{ }^{1} \mathrm{H}\right\}$ (125.70 MHz): $\delta-5.0\left(\mathrm{Si}^{1} \mathrm{CH}_{3}\right),-4.9\left(\mathrm{Si}^{2} \mathrm{CH}_{3}\right),-3.4\left(\mathrm{Si}^{3} \mathrm{CH}_{3}\right), 13.0$ $\left(\mathrm{CH}_{2} \mathrm{CH}_{2} \mathrm{CH}_{2} \mathrm{Cl}\right), 17.7\left(\mathrm{Si}^{0} \mathrm{CH}_{2}\right), 18.4\left(\mathrm{Si}^{2} \mathrm{CH}_{2} \mathrm{CH}_{2} \mathrm{CH}_{2} \mathrm{Si}^{3}\right), 18.52$ $\left(\mathrm{Si}^{1} \mathrm{CH}_{2} \mathrm{CH}_{2} \mathrm{CH}_{2} \mathrm{Si}^{2}\right), 18.55\left(\mathrm{Si}^{0} \mathrm{CH}_{2} \mathrm{CH}_{2} \mathrm{CH}_{2} \mathrm{Si}^{1}\right), 18.8\left(\mathrm{Si}^{2} \mathrm{CH}_{2} \mathrm{CH}_{2}-\right.$ $\left.\mathrm{CH}_{2} \mathrm{Si}^{3}\right), 18.96,19.03\left(\mathrm{Si}^{1} \mathrm{CH}_{2} \mathrm{CH}_{2} \mathrm{CH}_{2} \mathrm{Si}^{2}\right), 19.3\left(\mathrm{Si}^{0} \mathrm{CH}_{2} \mathrm{CH}_{2} \mathrm{CH}_{2}\right)$, $19.9\left(\mathrm{Si}^{2} \mathrm{CH}_{2} \mathrm{CH}_{2} \mathrm{CH}_{2} \mathrm{Si}^{3}\right), 27.7\left(\mathrm{CH}_{2} \mathrm{CH}_{2} \mathrm{Cl}\right), 48.0\left(\mathrm{CH}_{2} \mathrm{Cl}\right) .{ }^{29} \mathrm{Si}\left\{{ }^{1} \mathrm{H}\right\}$ (59.60 MHz): $\delta 0.38\left(\mathrm{Si}^{0}\right), 0.90\left(\mathrm{Si}^{1}\right), 0.98\left(\mathrm{Si}^{2}\right), 2.05\left(\mathrm{Si}^{3}\right)$.

4.2.4 Dendrimer (4). Mixture of chlorine terminated dendrimers 1 ( $2.00 \mathrm{~g}, 2.71 \mathrm{mmol})$ and sodium iodide $(8.11 \mathrm{~g}, 54.2$ $\mathrm{mmol}$ ) in $40 \mathrm{~mL}$ of butan-2-one was heated to reflux for 2 days. The reaction mixture was then cooled to room temperature. The product was extracted to diethyl ether $(2 \times 30 \mathrm{~mL})$, the extract 
filtered through silica gel and dried over anhydrous $\mathrm{MgSO}_{4}$. The volatiles were removed on the rotary evaporator and finally under high vacuum. Yield: $2.51 \mathrm{~g}(2.2 \mathrm{mmol}, 84 \%)$ of a yellow oil. Data for 4: NMR $\left(\mathrm{CDCl}_{3}\right):{ }^{1} \mathrm{H}(499.99 \mathrm{MHz}): \delta-0.02(\mathrm{~s}, 24 \mathrm{H}$, $\left.\mathrm{Si}^{1} \mathrm{CH}_{3}\right), 0.53-0.60\left(\mathrm{~m}, 24 \mathrm{H}, \mathrm{Si}^{0} \mathrm{CH}_{2}, \mathrm{CH}_{2} \mathrm{Si}^{1} \mathrm{CH}_{2}\right), 1.27-1.32(\mathrm{~m}$, $\left.8 \mathrm{H}, \mathrm{Si}^{0} \mathrm{CH}_{2} \mathrm{CH}_{2}\right), 1.77-1.84\left(\mathrm{~m}, 8 \mathrm{H}, \mathrm{CH}_{2} \mathrm{CH}_{2} \mathrm{I}\right), 3.18\left(\mathrm{t},{ }^{3} J_{\mathrm{HH}}=\right.$ $\left.7.3 \mathrm{~Hz}, 8 \mathrm{H}, \mathrm{CH}_{2} \mathrm{I}\right) .{ }^{13} \mathrm{C}\left\{{ }^{1} \mathrm{H}\right\}(125.70 \mathrm{MHz}): \delta-3.3\left(\mathrm{Si}^{1} \mathrm{CH}_{3}\right), 11.5$ $\left(\mathrm{CH}_{2} \mathrm{I}\right), 17.4\left(\mathrm{Si}^{0} \mathrm{CH}_{2}\right), 17.5\left(\mathrm{CH}_{2} \mathrm{CH}_{2} \mathrm{CH}_{2} \mathrm{I}\right), 18.5\left(\mathrm{Si}^{0} \mathrm{CH}_{2} \mathrm{CH}_{2}\right)$, $20.1\left(\mathrm{Si}^{0} \mathrm{CH}_{2} \mathrm{CH}_{2} \mathrm{CH}_{2}\right), 28.9\left(\mathrm{CH}_{2} \mathrm{CH}_{2} \mathrm{I}\right) .{ }^{29} \mathrm{Si}\left\{{ }^{1} \mathrm{H}\right\}(99.31 \mathrm{MHz})$ : $\delta 0.56\left(\mathrm{Si}^{0}\right), 1.47\left(\mathrm{Si}^{1}\right) . \operatorname{HRMS}\left(\mathrm{C}_{32} \mathrm{H}_{72} \mathrm{I}_{4} \mathrm{Si}_{5}\right):\left(\mathrm{ESI}^{+}\right) \mathrm{m} / z:\left[\mathrm{M}+\mathrm{NH}_{4}\right]^{+}$ calcd for $\mathrm{C}_{32} \mathrm{H}_{72} \mathrm{I}_{4} \mathrm{Si}_{5} \mathrm{NH}_{4}$ : 1122.0997, found: 1122.1000, $[\mathrm{M}+$ $\mathrm{Na}]^{+}$calcd for $\mathrm{C}_{32} \mathrm{H}_{72} \mathrm{I}_{4} \mathrm{Si}_{5} \mathrm{Na}$ : 1127.0551, found: 1127.0553 .

4.2.5 Dendrimer (5). The compound was synthesized according to the procedure for dendrimer 4 from dendrimer 2 ( $1 \mathrm{~g}, 0.56 \mathrm{mmol})$. Yield: $1.14 \mathrm{~g}(0.45 \mathrm{mmol}, 81 \%)$ of a yellow oil. Data for 5: $\mathrm{NMR}\left(\mathrm{CDCl}_{3}\right):{ }^{1} \mathrm{H}(499.99 \mathrm{MHz}): \delta-0.07(\mathrm{~s}, 12 \mathrm{H}$, $\mathrm{Si}^{1} \mathrm{CH}_{3}$ ), -0.02 (s, 48H, $\left.\mathrm{Si}^{2} \mathrm{CH}_{3}\right), 0.53-0.60\left(\mathrm{~m}, 64 \mathrm{H}, \mathrm{Si}^{0} \mathrm{CH}_{2}\right.$, $\left.\mathrm{CH}_{2} \mathrm{Si}^{1} \mathrm{CH}_{2}, \mathrm{CH}_{2} \mathrm{Si}^{2} \mathrm{CH}_{2}\right), 1.28-1.33\left(\mathrm{~m}, 24 \mathrm{H}, \mathrm{CH}_{2} \mathrm{CH}_{2} \mathrm{Si}^{1} \mathrm{CH}_{2}-\right.$ $\left.\mathrm{CH}_{2}\right), 1.78-1.84\left(\mathrm{~m}, 16 \mathrm{H}, \mathrm{CH}_{2} \mathrm{CH}_{2} \mathrm{I}\right), 3.18\left(\mathrm{t},{ }^{3} \mathrm{~J}_{\mathrm{HH}}=7.3 \mathrm{~Hz}, 16 \mathrm{H}\right.$, $\left.\mathrm{ICH}_{2}\right) .{ }^{13} \mathrm{C}\left\{{ }^{1} \mathrm{H}\right\}(125.70 \mathrm{MHz}): \delta-4.9\left(\mathrm{Si}^{1} \mathrm{CH}_{3}\right),-3.2\left(\mathrm{Si}^{2} \mathrm{CH}_{3}\right)$, $11.4\left(\mathrm{CH}_{2} \mathrm{I}\right), 17.5\left(\mathrm{CH}_{2} \mathrm{CH}_{2} \mathrm{CH}_{2} \mathrm{I}\right), 17.7\left(\mathrm{Si}^{0} \mathrm{CH}_{2}\right), 18.4\left(\mathrm{Si}^{1} \mathrm{CH}_{2}-\right.$ $\left.\mathrm{CH}_{2} \mathrm{CH}_{2} \mathrm{Si}^{2}\right)$, $18.6\left(\mathrm{Si}^{0} \mathrm{CH}_{2} \mathrm{CH}_{2} \mathrm{CH}_{2}\right), 18.8\left(\mathrm{Si}^{1} \mathrm{CH}_{2} \mathrm{CH}_{2} \mathrm{CH}_{2} \mathrm{Si}^{2}\right)$, 19.2 $\left(\mathrm{Si}^{0} \mathrm{CH}_{2} \mathrm{CH}_{2} \mathrm{CH}_{2}\right), 19.9\left(\mathrm{Si}^{1} \mathrm{CH}_{2} \mathrm{CH}_{2} \mathrm{CH}_{2} \mathrm{Si}^{2}\right), 28.9\left(\mathrm{CH}_{2} \mathrm{CH}_{2} \mathrm{I}\right)$. ${ }^{29} \mathrm{Si}\left\{{ }^{1} \mathrm{H}\right\}(59.60 \mathrm{MHz}): \delta 0.50\left(\mathrm{Si}^{0}\right), 0.99\left(\mathrm{Si}^{1}\right) ; 1.50\left(\mathrm{Si}^{2}\right)$. HRMS $\left(\mathrm{C}_{80} \mathrm{H}_{180} \mathrm{I}_{8} \mathrm{Si}_{13}\right):\left(\mathrm{ESI}^{+}\right) \mathrm{m} / z:\left[\mathrm{M}+\mathrm{NH}_{4}\right]^{+}$calcd for $\mathrm{C}_{80} \mathrm{H}_{180} \mathrm{I}_{8} \mathrm{Si}_{13^{-}}$ $\mathrm{NH}_{4}: 2540.3799$ found: 2540.3789 .

4.2.6 Dendrimer (6). The compound was synthesized according to the procedure for dendrimer 4 from dendrimer 3 ( $1 \mathrm{~g}$, $0.26 \mathrm{mmol})$. Yield: $1.18 \mathrm{~g}(0.22 \mathrm{mmol}, 86 \%)$ of a yellow oil. Data for 6 : NMR $\left(\mathrm{CDCl}_{3}\right):{ }^{1} \mathrm{H}(499.99 \mathrm{MHz}): \delta-0.06\left(\mathrm{~s}, 36 \mathrm{H}, \mathrm{Si}^{1,2} \mathrm{CH}_{3}\right),-0.02(\mathrm{~s}$, $96 \mathrm{H}, \mathrm{Si}^{3} \mathrm{CH}_{3}$ ), 0.54-0.61 (m, $144 \mathrm{H}, \mathrm{CH}_{2} \mathrm{CH}_{2} \mathrm{CH}_{2} \mathrm{Si}^{1} \mathrm{CH}_{2}, \mathrm{CH}_{2} \mathrm{Si}^{2} \mathrm{CH}_{2}$, $\mathrm{CH}_{2} \mathrm{Si}^{3} \mathrm{CH}_{2}$ ), 1.29-1.34 (m, 56H, $\mathrm{CH}_{2} \mathrm{CH}_{2} \mathrm{Si}^{1} \mathrm{CH}_{2} \mathrm{CH}_{2} \mathrm{CH}_{2} \mathrm{Si}^{2} \mathrm{CH}_{2} \mathrm{CH}_{2}$ ), 1.78-1.85 (m, 32H, $\left.\mathrm{CH}_{2} \mathrm{CH}_{2} \mathrm{I}\right), 3.18\left(\mathrm{t},{ }^{3} \mathrm{JHH}_{\mathrm{HH}}=7.2 \mathrm{~Hz}, 32 \mathrm{H}, \mathrm{ICH}_{2}\right) .{ }^{13} \mathrm{C}$ $\left\{{ }^{1} \mathrm{H}\right\}(125.70 \mathrm{MHz}): \delta-4.9\left(\mathrm{Si}^{1} \mathrm{CH}_{3}\right),-4.8\left(\mathrm{Si}^{2} \mathrm{CH}_{3}\right),-3.2\left(\mathrm{Si}^{3} \mathrm{CH}_{3}\right)$, $11.4\left(\mathrm{CH}_{2} \mathrm{I}\right), 17.5\left(\mathrm{CH}_{2} \mathrm{CH}_{2} \mathrm{CH}_{2} \mathrm{I}\right), 17.8\left(\mathrm{Si}^{0} \mathrm{CH}_{2}\right), 18.4\left(\mathrm{Si}^{2} \mathrm{CH}_{2} \mathrm{CH}_{2}-\right.$ $\left.\mathrm{CH}_{2} \mathrm{Si}^{3}\right), \quad 18.56 \quad\left(\mathrm{Si}^{1} \mathrm{CH}_{2} \mathrm{CH}_{2} \mathrm{CH}_{2} \mathrm{Si}^{2}\right), \quad 18.59 \quad\left(\mathrm{Si}^{0} \mathrm{CH}_{2} \mathrm{CH}_{2}\right), \quad 18.8$ $\left(\mathrm{Si}^{2} \mathrm{CH}_{2} \mathrm{CH}_{2} \mathrm{CH}_{2} \mathrm{Si}^{3}\right), 19.02,19.07\left(\mathrm{Si}^{1} \mathrm{CH}_{2} \mathrm{CH}_{2} \mathrm{CH}_{2} \mathrm{Si}^{2}\right), 19.4\left(\mathrm{Si}^{0} \mathrm{CH}_{2}-\right.$ $\left.\mathrm{CH}_{2} \mathrm{CH}_{2}\right), 20.0\left(\mathrm{Si}^{2} \mathrm{CH}_{2} \mathrm{CH}_{2} \mathrm{CH}_{2} \mathrm{Si}^{3}\right), 29.0\left(\mathrm{CH}_{2} \mathrm{CH}_{2} \mathrm{I}\right) .{ }^{29} \mathrm{Si}\left\{{ }^{1} \mathrm{H}\right\}(99.31$ $\mathrm{MHz}): \delta 0.35\left(\mathrm{Si}^{0}\right), 0.88\left(\mathrm{Si}^{1}\right), 0.97\left(\mathrm{Si}^{2}\right), 1.47\left(\mathrm{Si}^{3}\right)$.

4.2.7 Dendrimer (7). To a solution of dendrimer $4(1.2 \mathrm{~g}$, $1.09 \mathrm{mmol})$ in acetonitrile $(15 \mathrm{~mL})$ the commercial solution of trimethylamine ( $3 \mathrm{M}$ in isopropyl amine) was added $(4.3 \mathrm{~mL}$, $13.03 \mathrm{mmol}$ ) at $0{ }^{\circ} \mathrm{C}$. The reaction mixture was then stirred at room temperature for 48 hours. The solvents and the excess of phosphine were removed on the rotary evaporator and finally under high vacuum to give product as a white powder. Yield: $1.44 \mathrm{~g}$ (1.07 mmol, 99\%) data for 7: NMR (DMSO- $\left.d_{6}\right):{ }^{1} \mathrm{H}(499.99$ $\mathrm{MHz}): \delta-0.02\left(\mathrm{~s}, 24 \mathrm{H}, \mathrm{Si}^{1} \mathrm{CH}_{3}\right), 0.35-0.39\left(\mathrm{~m}, 8 \mathrm{H}, \mathrm{CH}_{2} \mathrm{CH}_{2}-\right.$ $\left.\mathrm{CH}_{2} \mathrm{~N}\right), 0.52-0.60\left(\mathrm{~m}, 16 \mathrm{H}, \mathrm{Si}^{0} \mathrm{CH}_{2} \mathrm{CH}_{2} \mathrm{CH}_{2}\right), 1.26-1.34(\mathrm{~m}, 8 \mathrm{H}$, $\mathrm{Si}^{0} \mathrm{CH}_{2} \mathrm{CH}_{2}$ ), 1.59-1.66 (m, 8H, $\left.\mathrm{CH}_{2} \mathrm{CH}_{2} \mathrm{~N}\right), 3.09$ (s, 36H, $\left.\mathrm{CH}_{3} \mathrm{~N}\right)$, 3.28-3.33 (m, 8H, CH $\left.{ }_{2} \mathrm{~N}\right) .{ }^{13} \mathrm{C}\left\{{ }^{1} \mathrm{H}\right\} \quad(125.70 \mathrm{MHz}): \delta-3.4$ $\left(\mathrm{Si}^{1} \mathrm{CH}_{3}\right), 11.0\left(\mathrm{CH}_{2} \mathrm{CH}_{2} \mathrm{CH}_{2} \mathrm{~N}\right), 16.8\left(\mathrm{Si}^{0} \mathrm{CH}_{2}\right), 16.9\left(\mathrm{CH}_{2} \mathrm{CH}_{2} \mathrm{~N}\right)$, $18.0 \quad\left(\mathrm{Si}^{0} \mathrm{CH}_{2} \mathrm{CH}_{2}\right), \quad 19.3 \quad\left(\mathrm{Si}^{0} \mathrm{CH}_{2} \mathrm{CH}_{2} \mathrm{CH}_{2}\right), \quad 52.1 \quad\left(\mathrm{CH}_{3} \mathrm{~N}\right)$, $67.7\left(\mathrm{CH}_{2} \mathrm{~N}\right) .{ }^{29} \mathrm{Si}\left\{{ }^{1} \mathrm{H}\right\}(99.31 \mathrm{MHz}): \delta \quad 0.74\left(\mathrm{Si}^{0}\right), 2.42\left(\mathrm{Si}^{1}\right)$. HRMS $\left(\mathrm{C}_{44} \mathrm{H}_{108} \mathrm{~N}_{4} \mathrm{Si}_{5} \mathrm{I}_{4}\right):\left(\mathrm{ESI}^{+}\right) \mathrm{m} / \mathrm{z}:\left[\mathrm{M}-\mathrm{I}^{-}\right]^{+}$calcd for $\mathrm{C}_{44} \mathrm{H}_{108} \mathrm{~N}_{4} \mathrm{Si}_{5} \mathrm{I}_{3}$ : 1213.4549 found: $1213.4536,\left[\mathrm{M}-2 \mathrm{I}^{-}\right]^{2+}$ calcd for $\mathrm{C}_{44} \mathrm{H}_{108} \mathrm{~N}_{4} \mathrm{Si}_{5} \mathrm{I}_{2}$ : 543.2749 found: 543.2749 , $\left[\mathrm{M}-3 \mathrm{I}^{-}\right]^{3+}$ calcd for $\mathrm{C}_{44} \mathrm{H}_{108} \mathrm{~N}_{4} \mathrm{Si}_{5} \mathrm{I}: 319.8816$ found: 319.8822 .

4.2.8 Dendrimer (8). The compound was synthesized according to the procedure for dendrimer 7 from dendrimer 5 (1.1 g, $0.44 \mathrm{mmol})$. Yield: $1.29 \mathrm{~g}(0.43 \mathrm{mmol}, 99 \%)$ of a white powder. Data for 8: NMR (DMSO- $\left.d_{6}\right):{ }^{1} \mathrm{H}(299.99 \mathrm{MHz}): \delta-0.09$ (s, $12 \mathrm{H}, \mathrm{Si}^{1} \mathrm{CH}_{3}$ ), -0.00 (s, 48H, $\left.\mathrm{Si}^{2} \mathrm{CH}_{3}\right), 0.37-0.40(\mathrm{~m}, 16 \mathrm{H}$, $\left.\mathrm{CH}_{2} \mathrm{CH}_{2} \mathrm{CH}_{2} \mathrm{~N}\right), 0.52-0.59\left(\mathrm{~m}, 48 \mathrm{H}, \mathrm{Si}^{0} \mathrm{CH}_{2}, \mathrm{CH}_{2} \mathrm{Si}^{1} \mathrm{CH}_{2} \mathrm{CH}_{2} \mathrm{CH}_{2}\right.$ ), 1.29-1.33 (m, 24H, $\left.\mathrm{CH}_{2} \mathrm{CH}_{2} \mathrm{Si}^{1} \mathrm{CH}_{2} \mathrm{CH}_{2}\right), 1.62-1.64(\mathrm{~m}, 16 \mathrm{H}$, $\left.\mathrm{CH}_{2} \mathrm{CH}_{2} \mathrm{~N}\right), 3.04-3.09\left(\mathrm{~m}, 72 \mathrm{H}, \mathrm{CH}_{3} \mathrm{~N}\right), 3.26-3.31(\mathrm{~m}, 16 \mathrm{H}$, $\left.\mathrm{NCH}_{2}\right) .{ }^{13} \mathrm{C}\left\{{ }^{1} \mathrm{H}\right\}(75.44 \mathrm{MHz}): \delta-4.9\left(\mathrm{Si}^{1} \mathrm{CH}_{3}\right),-3.4\left(\mathrm{Si}^{2} \mathrm{CH}_{3}\right)$, $11.2\left(\mathrm{CH}_{2} \mathrm{CH}_{2} \mathrm{CH}_{2} \mathrm{~N}\right), 17.0\left(\mathrm{CH}_{2} \mathrm{CH}_{2} \mathrm{~N}\right), 17.1\left(\mathrm{Si}^{0} \mathrm{CH}_{2}\right), \quad 18.0$ $\left(\mathrm{Si}^{1} \mathrm{CH}_{2} \mathrm{CH}_{2} \mathrm{CH}_{2} \mathrm{Si}^{2}\right), \quad 18.3 \quad\left(\mathrm{Si}^{0} \mathrm{CH}_{2} \mathrm{CH}_{2} \mathrm{CH}_{2} \mathrm{Si}^{1} \mathrm{CH}_{2}\right), \quad 18.5$ $\left(\mathrm{Si}^{0} \mathrm{CH}_{2} \mathrm{CH}_{2} \mathrm{CH}_{2}\right), 19.3\left(\mathrm{Si}^{1} \mathrm{CH}_{2} \mathrm{CH}_{2} \mathrm{CH}_{2} \mathrm{Si}^{2}\right), 52.2\left(\mathrm{NCH}_{3}\right), 67.9$ $\left(\mathrm{CH}_{2} \mathrm{~N}\right) .{ }^{29} \mathrm{Si}\left\{{ }^{1} \mathrm{H}\right\}(59.60 \mathrm{MHz}): \delta 0.74\left(\mathrm{Si}^{0}\right), 0.98\left(\mathrm{Si}^{1}\right) ; 2.34\left(\mathrm{Si}^{2}\right)$. HRMS $\left(\mathrm{C}_{104} \mathrm{H}_{252} \mathrm{I}_{8} \mathrm{~N}_{8} \mathrm{Si}_{13}\right):\left(\mathrm{ESI}^{+}\right) \mathrm{m} / \mathrm{z}:\left[\mathrm{M}-2 \mathrm{I}^{-}\right]^{2+}$ calcd for $\mathrm{C}_{104} \mathrm{H}_{252} \mathrm{I}_{6} \mathrm{~N}_{8} \mathrm{Si}_{13}: 1370.5623$ found: $1370.5612,\left[\mathrm{M}-3 \mathrm{I}^{-}\right]^{3+}$ calcd for $\mathrm{C}_{104} \mathrm{H}_{252} \mathrm{I}_{5} \mathrm{~N}_{8} \mathrm{Si}_{13}$ : 871.4065 found: 871.4065, $\left[\mathrm{M}-4 \mathrm{I}^{-}\right]^{4+}$ calcd for $\mathrm{C}_{104} \mathrm{H}_{252} \mathrm{I}_{4} \mathrm{~N}_{8} \mathrm{Si}_{13}$ : 621.8286 found: 621.8289, [M $\left.5 \mathrm{I}^{-}\right]^{5+}$ calcd for $\mathrm{C}_{104} \mathrm{H}_{252} \mathrm{I}_{3} \mathrm{~N}_{8} \mathrm{Si}_{13}: 472.0819$ found: 472.0813 , [M $\left.-6 \mathrm{I}^{-}\right]^{6+}$ calcd for $\mathrm{C}_{104} \mathrm{H}_{252} \mathrm{I}_{2} \mathrm{~N}_{8} \mathrm{Si}_{13}: 372.2507$ found: 372.2527 , $\left[\mathrm{M}-7 \mathrm{I}^{-}\right]^{7+}$ calcd for $\mathrm{C}_{104} \mathrm{H}_{252} \mathrm{IN}_{8} \mathrm{Si}_{13}: 300.9428$ found: 300.9423 .

4.2.9 Dendrimer (9). The compound was synthesized according to the procedure for dendrimer 7 from dendrimer 6 (1 g, $0.19 \mathrm{mmol})$. Yield: $1.14 \mathrm{~g}(0.18 \mathrm{mmol}, 97 \%)$ of a white powder. Data for 9: NMR (DMSO- $\left.d_{6}\right):{ }^{1} \mathrm{H}(499.99 \mathrm{MHz}): \delta-0.11$ (s, $12 \mathrm{H}, \mathrm{Si}^{1} \mathrm{CH}_{3}$ ), -0.09 (s, 24H, Si $\left.{ }^{2} \mathrm{CH}_{3}\right), 0.00$ (s, 96H, Si ${ }^{3} \mathrm{CH}_{3}$ ), 0.37-0.40 (m, 32H, $\left.\mathrm{CH}_{2} \mathrm{CH}_{2} \mathrm{CH}_{2} \mathrm{~N}\right), 0.51-0.59\left(\mathrm{~m}, 112 \mathrm{H}, \mathrm{Si}^{0} \mathrm{CH}_{2}\right.$, $\left.\mathrm{CH}_{2} \mathrm{Si}^{1} \mathrm{CH}_{2}, \quad \mathrm{CH}_{2} \mathrm{Si}^{2} \mathrm{CH}_{2} \mathrm{CH}_{2} \mathrm{CH}_{2}\right), \quad 1.28-1.33 \quad(\mathrm{~m}, \quad 56 \mathrm{H}$, $\left.\mathrm{CH}_{2} \mathrm{CH}_{2} \mathrm{Si}^{1} \mathrm{CH}_{2} \mathrm{CH}_{2} \mathrm{CH}_{2} \mathrm{Si}^{2} \mathrm{CH}_{2} \mathrm{CH}_{2}\right), \quad 1.61-1.66(\mathrm{~m}, 32 \mathrm{H}$, $\mathrm{CH}_{2} \mathrm{CH}_{2} \mathrm{~N}$ ), 3.08 (br s, $144 \mathrm{H}, \mathrm{NCH}_{3}$ ), 3.22-3.28 (m, 32H, $\mathrm{NCH}_{2}$ ). ${ }^{13} \mathrm{C}\left\{{ }^{1} \mathrm{H}\right\}(125.70 \mathrm{MHz}): \delta-4.9\left(\mathrm{Si}^{1,2} \mathrm{CH}_{3}\right),-3.4\left(\mathrm{Si}^{3} \mathrm{CH}_{3}\right), 11.2$ $\left(\mathrm{CH}_{2} \mathrm{CH}_{2} \mathrm{CH}_{2} \mathrm{~N}\right), 17.0\left(\mathrm{CH}_{2} \mathrm{CH}_{2} \mathrm{~N}\right), 18.0\left(\mathrm{Si}^{2} \mathrm{CH}_{2} \mathrm{CH}_{2} \mathrm{CH}_{2} \mathrm{Si}^{3}\right), 18.2$ $\left(\mathrm{Si}^{1} \mathrm{CH}_{2} \mathrm{CH}_{2} \mathrm{CH}_{2} \mathrm{Si}^{2} \mathrm{CH}_{2}\right), \quad 18.4 \quad\left(\mathrm{Si}^{1} \mathrm{CH}_{2} \mathrm{CH}_{2} \mathrm{CH}_{2} \mathrm{Si}^{2}\right), \quad 19.4$, $\left(\mathrm{Si}^{2} \mathrm{CH}_{2} \mathrm{CH}_{2} \mathrm{CH}_{2} \mathrm{Si}^{3}\right), 52.2\left(\mathrm{CH}_{3} \mathrm{~N}\right), 67.9\left(\mathrm{CH}_{2} \mathrm{~N}\right),\left(\mathrm{Si}^{0} \mathrm{CH}_{2} \mathrm{CH}_{2} \mathrm{CH}_{2}\right.$ were overlap or not detected). ${ }^{29} \mathrm{Si}\left\{{ }^{1} \mathrm{H}\right\}(99.31 \mathrm{MHz}): \delta\left(\mathrm{Si}^{0}\right.$ was not detected), $1.06\left(\mathrm{Si}^{1,2}\right), 2.42\left(\mathrm{Si}^{3}\right)$. HRMS $\left(\mathrm{C}_{224} \mathrm{H}_{540} \mathrm{~N}_{16} \mathrm{Si}_{29} \mathrm{I}_{16}\right)$ : $\left(\mathrm{ESI}^{+}\right) \mathrm{m} / z:\left[\mathrm{M}-4 \mathrm{I}^{-}\right]^{4+}$ calcd for $\mathrm{C}_{224} \mathrm{H}_{540} \mathrm{~N}_{16} \mathrm{Si}_{29} \mathrm{I}_{12}$ : 1448.8655 found: 1448.8647, $\left[\mathrm{M}-5 \mathrm{I}^{-}\right]^{5+}$ calcd for $\mathrm{C}_{224} \mathrm{H}_{540} \mathrm{~N}_{16} \mathrm{Si}_{29} \mathrm{I}_{11}: 1133.7114$ found: $1133.7114,\left[\mathrm{M}-6 \mathrm{I}^{-}\right]^{6+}$ calcd for $\mathrm{C}_{224} \mathrm{H}_{540} \mathrm{~N}_{16} \mathrm{Si}_{29} \mathrm{I}_{10}$ : 923.6086 found: 923.6073. Anal. calc. $\mathrm{C}_{224} \mathrm{H}_{540} \mathrm{I}_{16} \mathrm{~N}_{16} \mathrm{Si}_{29}\left(6303.74 \mathrm{~g} \mathrm{~mol}^{-1}\right): \mathrm{C}$, 42.68; H, 8.63; exp.: C, 42.97; H, 8.89.

4.2.10 Dendrimer (10). To a solution of dendrimer $4(1.2 \mathrm{~g}$, $1.09 \mathrm{mmol})$ in acetonitrile $(15 \mathrm{~mL})$ the commercial solution of trimethylphosphine $(1 \mathrm{M}$ in THF) was added $(8.7 \mathrm{~mL}, 8.67$ $\mathrm{mmol}$ ) at $0{ }^{\circ} \mathrm{C}$. The reaction mixture was then stirred at room temperature for 48 hours. The solvents and the excess of phosphine were removed on the rotary evaporator and finally under high vacuum to give product as a white powder. Yield: $1.52 \mathrm{~g}$ (1.07 mmol, 99\%). Data for 10: NMR (DMSO- $\left.d_{6}\right):{ }^{1} \mathrm{H}$ $(299.99 \mathrm{MHz}): \delta-0.01\left(\mathrm{~s}, 24 \mathrm{H}, \mathrm{Si}^{1} \mathrm{CH}_{3}\right), 0.52-0.62(\mathrm{~m}, 24 \mathrm{H}$, $\mathrm{Si}^{0} \mathrm{CH}_{2}, \mathrm{CH}_{2} \mathrm{Si}^{1} \mathrm{CH}_{2}$ ), 1.26-1.36 (m, 8H, $\mathrm{Si}^{0} \mathrm{CH}_{2} \mathrm{CH}_{2}$ ), 1.45-1.54 $\left(\mathrm{m}, 8 \mathrm{H}, \mathrm{PCH}_{2} \mathrm{CH}_{2}\right), 1.82\left(\mathrm{~d},{ }^{2} J_{\mathrm{HP}}=14.8 \mathrm{~Hz}, 48 \mathrm{H}, \mathrm{PCH}_{3}\right), 2.14-$ $2.24(\mathrm{~m}, 8 \mathrm{H}, \mathrm{PCH}) .{ }^{13} \mathrm{C}\left\{{ }^{1} \mathrm{H}\right\}(75.44 \mathrm{MHz}): \delta-3.4\left(\mathrm{~s}, \mathrm{Si}^{1} \mathrm{CH}_{3}\right), 7.3$ $\left(\mathrm{d},{ }^{1} J_{\mathrm{PC}}=53.7 \mathrm{~Hz}, \mathrm{PCH}_{3}\right), 15.8\left(\mathrm{~d},{ }^{2} J_{\mathrm{PC}}=4.5 \mathrm{~Hz}, \mathrm{PCH}_{2} \mathrm{CH}_{2}\right), 16.7$ $\left(\mathrm{d},{ }^{3} J_{\mathrm{PC}}=14.1 \mathrm{~Hz}, \mathrm{PCH}_{2} \mathrm{CH}_{2} \mathrm{CH}_{2}\right), 16.9\left(\mathrm{~s}, \mathrm{Si}^{0} \mathrm{CH}_{2}\right), 18.1$ (s, $\mathrm{Si}^{0} \mathrm{CH}_{2} \mathrm{CH}_{2}$ ), 19.4 (s, $\mathrm{Si}^{0} \mathrm{CH}_{2} \mathrm{CH}_{2} \mathrm{CH}_{2}$ ), 25.9 (d, ${ }^{1} J_{\mathrm{PC}}=49.6 \mathrm{~Hz}$, 
$\left.\mathrm{CH}_{2} \mathrm{P}\right) .{ }^{29} \mathrm{Si}\left\{{ }^{1} \mathrm{H}\right\}(59.60 \mathrm{MHz}): \delta 0.74\left(\mathrm{Si}^{0}\right), 1.66\left(\mathrm{~d},{ }^{4} J_{\mathrm{SiP}}=2.4 \mathrm{~Hz}\right.$, $\left.\mathrm{Si}^{1}\right) .{ }^{31} \mathrm{P}\left\{{ }^{1} \mathrm{H}\right\}(121.44 \mathrm{MHz}): \delta$ 26.61. HRMS $\left(\mathrm{C}_{44} \mathrm{H}_{108} \mathrm{I}_{4} \mathrm{P}_{4} \mathrm{Si}_{5}\right)$ : $\left(\mathrm{ESI}^{+}\right) \mathrm{m} / \mathrm{z}:\left[\mathrm{M}-\mathrm{I}^{-}\right]^{+}$calcd for $\mathrm{C}_{44} \mathrm{H}_{108} \mathrm{I}_{3} \mathrm{P}_{4} \mathrm{Si}_{5}: 1281.3376$ found: 1281.3373, $\left[\mathrm{M}-2 \mathrm{I}^{-}\right]^{2+}$ calcd for $\mathrm{C}_{44} \mathrm{H}_{108} \mathrm{I}_{2} \mathrm{P}_{4} \mathrm{Si}_{5}$ : 557.2163, found: $557.2169,\left[\mathrm{M}-3 \mathrm{I}^{-}\right]^{3+}$ calcd for $\mathrm{C}_{44} \mathrm{H}_{108} \mathrm{IP}_{4} \mathrm{Si}_{5}$ : 342.5092, found: 342.5118 .

4.2.11 Dendrimer (11). The compound was synthesized according to the procedure for dendrimer $\mathbf{1 0}$ from dendrimer $\mathbf{5}$ ( $1 \mathrm{~g}, 0.40 \mathrm{mmol})$. Yield: $1.22 \mathrm{~g}(0.39 \mathrm{mmol}, 98 \%)$ of a white powder. Data for 11: NMR (DMSO- $\left.d_{6}\right):{ }^{1} \mathrm{H}(499.99 \mathrm{MHz}): \delta-0.09$ $\left(\mathrm{s}, 12 \mathrm{H}, \mathrm{Si}^{1} \mathrm{CH}_{3}\right),-0.02\left(\mathrm{~s}, 48 \mathrm{H}, \mathrm{Si}^{2} \mathrm{CH}_{3}\right), 0.52-0.60(\mathrm{~m}, 64 \mathrm{H}$, $\left.\mathrm{Si}^{0} \mathrm{CH}_{2}, \mathrm{CH}_{2} \mathrm{Si}^{1} \mathrm{CH}_{2}, \mathrm{CH}_{2} \mathrm{Si}^{2} \mathrm{CH}_{2}\right), 1.27-1.33\left(\mathrm{~m}, 24 \mathrm{H}, \mathrm{CH}_{2} \mathrm{CH}_{2}-\right.$ $\mathrm{Si}^{1} \mathrm{CH}_{2} \mathrm{CH}_{2}$ ), 1.47-1.52 (m, 16H, $\left.\mathrm{CH}_{2} \mathrm{CH}_{2} \mathrm{P}\right), 1.83\left(\mathrm{~d},{ }^{1} J_{\mathrm{HP}}=\right.$ $\left.14.8 \mathrm{~Hz}, 72 \mathrm{H}, \mathrm{CH}_{3} \mathrm{P}\right), 2.17-2.23\left(\mathrm{~m}, 16 \mathrm{H}, \mathrm{PCH}_{2}\right) .{ }^{13} \mathrm{C}\left\{{ }^{1} \mathrm{H}\right\}(125.70$ $\mathrm{MHz}): \delta-4.9\left(\mathrm{Si}^{1} \mathrm{CH}_{3}\right),-3.4\left(\mathrm{Si}^{2} \mathrm{CH}_{3}\right), 7.4\left(\mathrm{~d},{ }^{1} J_{\mathrm{CP}}=53.6 \mathrm{~Hz}\right.$, $\left.\mathrm{PCH}_{3}\right), 15.8\left(\mathrm{~d},{ }^{2} J_{\mathrm{CP}}=4.4 \mathrm{~Hz}, \mathrm{CH}_{2} \mathrm{CH}_{2} \mathrm{P}\right), 16.6\left(\mathrm{~d},{ }^{3} J_{\mathrm{CP}}=13.9 \mathrm{~Hz}\right.$, $\left.\mathrm{CH}_{2} \mathrm{CH}_{2} \mathrm{CH}_{2} \mathrm{P}\right), 17.1\left(\mathrm{Si}^{0} \mathrm{CH}_{2}\right), 17.9\left(\mathrm{Si}^{1} \mathrm{CH}_{2} \mathrm{CH}_{2} \mathrm{CH}_{2} \mathrm{Si}^{2}\right), 18.1$ $\left(\mathrm{Si}^{0} \mathrm{CH}_{2} \mathrm{CH}_{2} \mathrm{CH}_{2} \mathrm{Si}^{0} \mathrm{CH}_{2}\right), 18.4\left(\mathrm{Si}^{0} \mathrm{CH}_{2} \mathrm{CH}_{2} \mathrm{CH}_{2}\right), 19.3\left(\mathrm{Si}^{1} \mathrm{CH}_{2}-\right.$ $\mathrm{CH}_{2} \mathrm{CH}_{2} \mathrm{Si}^{2}$ ), $25.9\left(\mathrm{~d},{ }^{1} \mathrm{~J}_{\mathrm{CP}}=49.7 \mathrm{~Hz}, \mathrm{CH}_{2} \mathrm{P}\right) .{ }^{29} \mathrm{Si}\left\{{ }^{1} \mathrm{H}\right\}$ inept (99.31 $\mathrm{MHz}): \delta 0.82\left(\mathrm{Si}^{0}\right), 1.07\left(\mathrm{Si}^{1}\right), 1.64\left(\mathrm{~d},{ }^{4} J_{\mathrm{SiP}}=2.3 \mathrm{~Hz}, \mathrm{Si}^{2}\right) .{ }^{31} \mathrm{P}\left\{{ }^{1} \mathrm{H}\right\}$ (202.37 MHz): $\delta$ 26.59. HRMS $\left(\mathrm{C}_{104} \mathrm{H}_{252} \mathrm{I}_{8} \mathrm{P}_{8} \mathrm{Si}_{13}\right):\left(\mathrm{ESI}^{+}\right) \mathrm{m} / \mathrm{z}:[\mathrm{M}-$ $\left.2 \mathrm{I}^{-}\right]^{2+}$ calcd for $\mathrm{C}_{104} \mathrm{H}_{252} \mathrm{I}_{6} \mathrm{P}_{8} \mathrm{Si}_{13}: 1437.4438$ found: 1437.4433, $\left[\mathrm{M}-3 \mathrm{I}^{-}\right]^{3+}$ calcd for $\mathrm{C}_{104} \mathrm{H}_{252} \mathrm{I}_{5} \mathrm{P}_{8} \mathrm{Si}_{13}$ : 915.9941 found: 915.9941, $\left[\mathrm{M}-4 \mathrm{I}^{-}\right]^{4+}$ calcd for $\mathrm{C}_{104} \mathrm{H}_{252} \mathrm{I}_{4} \mathrm{P}_{8} \mathrm{Si}_{13}: 655.2694$ found: 655.2692, $\left[\mathrm{M}-5 \mathrm{I}^{-}\right]^{5+}$ calcd for $\mathrm{C}_{104} \mathrm{H}_{252} \mathrm{I}_{3} \mathrm{P}_{8} \mathrm{Si}_{13}$ : 498.8345 found: 498.8340, $\left[\mathrm{M}-6 \mathrm{I}^{-}\right]^{6+}$ calcd for $\mathrm{C}_{104} \mathrm{H}_{252} \mathrm{I}_{2} \mathrm{P}_{8} \mathrm{Si}_{13}: 394.5446$ found: 394.5444 , $\left[\mathrm{M}-7 \mathrm{I}^{-}\right]^{7+}$ calcd for $\mathrm{C}_{104} \mathrm{H}_{252} \mathrm{IP}_{8} \mathrm{Si}_{13}$ : 320.0517 found: 320.0511 .

4.2.12 Dendrimer (12). The compound was synthesized according to the procedure for dendrimer $\mathbf{1 0}$ from dendrimer $\mathbf{6}$ ( $1 \mathrm{~g}, 0.19 \mathrm{mmol})$. Yield: $1.20 \mathrm{~g}(0.18 \mathrm{mmol}, 98 \%)$ of a white powder. Data for 12: NMR (DMSO- $\left.d_{6}\right):{ }^{1} \mathrm{H}(499.99 \mathrm{MHz}): \delta-0.11$ (s, $\left.12 \mathrm{H}, \mathrm{Si}^{1} \mathrm{CH}_{3}\right),-0.09$ (s, 24H, $\left.\mathrm{Si}^{2} \mathrm{CH}_{3}\right),-0.02\left(\mathrm{~s}, 96 \mathrm{H}, \mathrm{Si}^{3} \mathrm{CH}_{3}\right)$, 0.52-0.60 (m, $144 \mathrm{H}, \mathrm{Si}^{0} \mathrm{CH}_{2}, \mathrm{CH}_{2} \mathrm{Si}^{1} \mathrm{CH}_{2}, \mathrm{CH}_{2} \mathrm{Si}^{2} \mathrm{CH}_{2}, \mathrm{CH}_{2}-$ $\mathrm{Si}^{3} \mathrm{CH}_{2}$ ), 1.27-1.33 (m, 56H, $\mathrm{CH}_{2} \mathrm{CH}_{2} \mathrm{Si}^{1} \mathrm{CH}_{2} \mathrm{CH}_{2} \mathrm{CH}_{2} \mathrm{Si}^{2} \mathrm{CH}_{2} \mathrm{CH}_{2}$ ), 1.46-1.53 (m, 32H, $\left.\mathrm{CH}_{2} \mathrm{CH}_{2} \mathrm{P}\right), 1.88\left(\mathrm{~d},{ }^{1} J_{\mathrm{PH}}=14.8 \mathrm{~Hz}, 144 \mathrm{H}\right.$, $\left.\mathrm{PCH}_{3}\right), 2.22-2.28\left(\mathrm{~d}, 32 \mathrm{H}, \mathrm{PCH}_{2}\right) .{ }^{13} \mathrm{C}\left\{{ }^{1} \mathrm{H}\right\}(125.70 \mathrm{MHz}): \delta-4.84$ $\left(\mathrm{Si}^{2} \mathrm{CH}_{3}\right),-4.81\left(\mathrm{Si}^{1} \mathrm{CH}_{3}\right),-3.3\left(\mathrm{Si}^{3} \mathrm{CH}_{3}\right), 7.5\left(\mathrm{~d},{ }^{1} J_{\mathrm{PC}}=\right.$ $\left.53.7 \mathrm{~Hz}, \mathrm{CH}_{3} \mathrm{P}\right), 15.9\left(\mathrm{~d},{ }^{2} \mathrm{~J}_{\mathrm{CP}}=3.9 \mathrm{~Hz}, \mathrm{CH}_{2} \mathrm{CH}_{2} \mathrm{P}\right), 16.7\left(\mathrm{~d},{ }^{3} J_{\mathrm{CP}}=\right.$

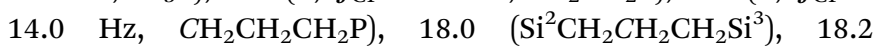
$\left(\mathrm{Si}^{1} \mathrm{CH}_{2} \mathrm{CH}_{2} \mathrm{CH}_{2} \mathrm{Si}^{2}\right), 18.3\left(\mathrm{Si}^{2} \mathrm{CH}_{2} \mathrm{CH}_{2} \mathrm{CH}_{2} \mathrm{Si}^{3}\right), 18.4\left(\mathrm{Si}^{1} \mathrm{CH}_{2}-\right.$ $\mathrm{CH}_{2} \mathrm{CH}_{2} \mathrm{Si}^{2}$ ), 19.5, $\left(\mathrm{Si}^{2} \mathrm{CH}_{2} \mathrm{CH}_{2} \mathrm{CH}_{2} \mathrm{Si}^{3}\right), 25.9$ (d, ${ }^{1} J_{\mathrm{CP}}=49.4 \mathrm{~Hz}$, $\left.\mathrm{CH}_{2} \mathrm{P}\right)$. ( $\mathrm{Si}^{\mathrm{O}} \mathrm{CH}_{2} \mathrm{CH}_{2} \mathrm{CH}_{2}$ were overlap or not detected). ${ }^{29} \mathrm{Si}\left\{{ }^{1} \mathrm{H}\right\}$ (99.31 MHz): $\delta\left(\mathrm{Si}^{0}\right.$ was not detected), $1.05\left(\mathrm{Si}^{1,2}\right), 1.62\left(\mathrm{~d},{ }^{4} J_{\mathrm{SiP}}=\right.$ $\left.2.2 \mathrm{~Hz}, \quad \mathrm{Si}^{3}\right) .{ }^{31} \mathrm{P} \quad\left\{{ }^{1} \mathrm{H}\right\} \quad(202.37 \quad \mathrm{MHz}): \quad \delta$ 26.59. $\quad$ HRMS $\left(\mathrm{C}_{224} \mathrm{H}_{540} \mathrm{I}_{16} \mathrm{P}_{16} \mathrm{Si}_{29}\right):\left(\mathrm{ESI}^{+}\right) \mathrm{m} / \mathrm{z}:\left[\mathrm{M}-3 \mathrm{I}^{-}\right]^{3+}$ calcd for $\mathrm{C}_{224} \mathrm{H}_{540} \mathrm{I}_{13} \mathrm{P}_{16} \mathrm{Si}_{29}$ : 2064.6327 found: 2064.6333, $\left[\mathrm{M}-4 \mathrm{I}^{-}\right]^{4+}$ calcd for $\mathrm{C}_{224} \mathrm{H}_{540} \mathrm{I}_{12} \mathrm{P}_{16} \mathrm{Si}_{29}$ : 1516.7483 found: 1516.7482 , [M $\left.5 \mathrm{I}^{-}\right]^{5+}$ calcd for $\mathrm{C}_{224} \mathrm{H}_{540} \mathrm{I}_{11} \mathrm{P}_{16} \mathrm{Si}_{29}: 1188.0176$ found: 1188.0170 , $\left[\mathrm{M}-6 \mathrm{I}^{-}\right]^{6+}$ calcd for $\mathrm{C}_{224} \mathrm{H}_{540} \mathrm{I}_{10} \mathrm{P}_{16} \mathrm{Si}_{29}$ : 968.8639 found: 968.8644, $\left[\mathrm{M}-7 \mathrm{I}^{-}\right]^{7+}$ calcd for $\mathrm{C}_{224} \mathrm{H}_{540} \mathrm{I}_{9} \mathrm{P}_{16} \mathrm{Si}_{29}: 812.3254$ found: 812.3267, $\left[\mathrm{M}-8 \mathrm{I}^{-}\right]^{8+}$ calcd for $\mathrm{C}_{224} \mathrm{H}_{540} \mathrm{I}_{8} \mathrm{P}_{16} \mathrm{Si}_{29}$ : 694.9216 found: 694.9223 .

4.2.13 Dendrimers (13-18, 22-24, 28-30). Dendrimers 1318, 22-24, 28-30 were synthetized according to similar procedure using iododerivate $\mathbf{4}$ for first $\mathbf{5}$ for second and $\mathbf{6}$ for third generation. Appropriate phosphine was used in slight excess. In all cases yields are in range between $97-100 \%$. Dendrimers 1415 were prepared as colourless liquids, 16-33 as white powders.

4.2.14 Dendrimer (13). To a solution of dendrimer 4 $(1.2 \mathrm{~g}, 1.09 \mathrm{mmol})$ in acetonitrile $(15 \mathrm{~mL})$ the diethyl-(3hydroxypropyl)-phosphin was added $(8.7 \mathrm{~mL}, 8.67 \mathrm{mmol})$. The reaction mixture was then stirred at $70{ }^{\circ} \mathrm{C}$ for 48 hours. The solvents were removed on the rotary evaporator and to a crude product toluene $(2 \mathrm{~mL})$ was added and mixture was stirred at $80{ }^{\circ} \mathrm{C}$ for $6 \mathrm{~h}$ followed by filtration at room temperature and drying of product at vacuum. The product was obtained as a colourless liquid. Yield: $1.52 \mathrm{~g}(1.07 \mathrm{mmol}, 99 \%)$. Data for 13: NMR (DMSO- $d_{6}$ ): ${ }^{1} \mathrm{H}$ (499.99 MHz): $\delta-0.02\left(\mathrm{~s}, 24 \mathrm{H}, \mathrm{Si}^{1} \mathrm{CH}_{3}\right.$ ), 0.53-0.59 (m, 16H, Si $\left.{ }^{0} \mathrm{CH}_{2} \mathrm{CH}_{2} \mathrm{CH}_{2}\right), 0.60-0.64\left(\mathrm{~m}, 8 \mathrm{H}, \mathrm{Si}^{1} \mathrm{CH}_{2}-\right.$ $\mathrm{CH}_{2} \mathrm{CH}_{2} \mathrm{P}$ ), $1.13\left(\mathrm{dt},{ }^{3} J_{\mathrm{HP}}=18.2 \mathrm{~Hz},{ }^{3} \mathrm{~J}_{\mathrm{HH}}=7.7 \mathrm{~Hz}, 24 \mathrm{H}, \mathrm{CH}_{3}\right.$ ), 1.27-1.34 (m, 8H, Si $\left.{ }^{0} \mathrm{CH}_{2} \mathrm{CH}_{2}\right), 1.44-1.52\left(\mathrm{~m}, 8 \mathrm{H}, \mathrm{Si}^{1} \mathrm{CH}_{2} \mathrm{CH}_{2}\right.$ $\mathrm{CH}_{2} \mathrm{P}$ ), 1.60-1.66 (m, 8H, $\left.\mathrm{CH}_{2} \mathrm{CH}_{2} \mathrm{OH}\right), 2.19-2.29(\mathrm{~m}, 32 \mathrm{H}$, $\left.\mathrm{CH}_{2} \mathrm{P}\right), 3.48\left(\mathrm{q},{ }^{3} J_{\mathrm{HH}}=5.6 \mathrm{~Hz}, 8 \mathrm{H}, \mathrm{CH}_{2} \mathrm{OH}\right), 4.77\left(\mathrm{t},{ }^{3} \mathrm{~J}_{\mathrm{HH}}=\right.$ $5.3 \mathrm{~Hz}, 4 \mathrm{H}, \mathrm{OH}) .{ }^{13} \mathrm{C}\left\{{ }^{1} \mathrm{H}\right\}(125.70 \mathrm{MHz}): \delta-3.4\left(\mathrm{~s}, \mathrm{Si}^{1} \mathrm{CH}_{3}\right), 5.3$ $\left(\mathrm{d},{ }^{2} J_{\mathrm{CP}}=5.5 \mathrm{~Hz}, \mathrm{PCH}_{2} \mathrm{CH}_{3}\right), 11.1\left(\mathrm{~d},{ }^{1} J_{\mathrm{CP}}=48.6 \mathrm{~Hz}, \mathrm{CH}_{3} \mathrm{CH}_{2} \mathrm{P}\right)$, $14.0\left(\mathrm{~d},{ }^{1} J_{\mathrm{CP}}=48.9 \mathrm{~Hz}, \mathrm{PCH}_{2} \mathrm{CH}_{2} \mathrm{CH}_{2} \mathrm{OH}\right), 15.9\left(\mathrm{~d},{ }^{2} J_{\mathrm{CP}}=4.6 \mathrm{~Hz}\right.$, $\mathrm{Si}^{1} \mathrm{CH}_{2} \mathrm{CH}_{2} \mathrm{CH}_{2} \mathrm{P}$ ), $16.92\left(\mathrm{~s}, \mathrm{Si}^{0} \mathrm{CH}_{2}\right.$ ), 19.94 (d, ${ }^{3} J_{\mathrm{CP}}=12.8 \mathrm{~Hz}$, $\mathrm{Si}^{1} \mathrm{CH}_{2} \mathrm{CH}_{2} \mathrm{CH}_{2} \mathrm{P}$ ), $18.1\left(\mathrm{Si}^{0} \mathrm{CH}_{2} \mathrm{CH}_{2}\right.$ ), 19.4 (s, $\mathrm{Si}^{0} \mathrm{CH}_{2} \mathrm{CH}_{2} \mathrm{CH}_{2}$ ), $20.7\left(\mathrm{~d},{ }^{1} J_{\mathrm{CP}}=44.7 \mathrm{~Hz}, \mathrm{Si}^{1} \mathrm{CH}_{2} \mathrm{CH}_{2} \mathrm{CH}_{2} \mathrm{P}\right), 24.0\left(\mathrm{~d},{ }^{2} J_{\mathrm{CP}}=4.3 \mathrm{~Hz}\right.$, $\mathrm{OHCH}_{2} \mathrm{CH}_{2} \mathrm{CH}_{2} \mathrm{P}$ ), 60.4 (d, ${ }^{3} J_{\mathrm{CP}}=15.4 \mathrm{~Hz}, \mathrm{OHCH}_{2}$ ). ${ }^{29} \mathrm{Si}\left\{{ }^{1} \mathrm{H}\right\}$ (99.31 MHz): $\delta 0.71\left(\mathrm{~s}, \mathrm{Si}^{0}\right), 1.58\left(\mathrm{~d},{ }^{4} J_{\mathrm{SiP}}=2.5 \mathrm{~Hz}, \mathrm{Si}^{1}\right) .{ }^{31} \mathrm{P}$ $\left\{{ }^{1} \mathrm{H}\right\}(121.41 \mathrm{MHz}): \delta$ 42.63. HRMS $\left(\mathrm{C}_{60} \mathrm{H}_{140} \mathrm{O}_{4} \mathrm{Si}_{5} \mathrm{I}_{4}\right):\left(\mathrm{ESI}^{+}\right) \mathrm{m} / z$ : $\left[\mathrm{M}-\mathrm{I}^{-}\right]^{+}$calcd for $\mathrm{C}_{60} \mathrm{H}_{140} \mathrm{O}_{4} \mathrm{Si}_{5} \mathrm{I}_{3}: 1569.5677$ found: 1569.5668 , $\left[\mathrm{M}-2 \mathrm{I}^{-}\right]^{2+}$ calcd for $\mathrm{C}_{60} \mathrm{H}_{140} \mathrm{O}_{4} \mathrm{Si}_{5} \mathrm{I}_{2}: 721.3313$ found: 721.3316 , $\left[\mathrm{M}-3 \mathrm{I}^{-}\right]^{3+}$ calcd for $\mathrm{C}_{60} \mathrm{H}_{140} \mathrm{O}_{4} \mathrm{Si}_{5} \mathrm{I}: 438.5858$ found: 438.5856 , $\left[\mathrm{M}-4 \mathrm{I}^{-}\right]^{4+}$ calcd for $\mathrm{C}_{60} \mathrm{H}_{140} \mathrm{O}_{4} \mathrm{Si}_{5}: 297.2131$ found: 297.2135 . Anal. calc. $\mathrm{C}_{60} \mathrm{H}_{140} \mathrm{I}_{4} \mathrm{O}_{4} \mathrm{P}_{4} \mathrm{Si}_{5}\left(1697.69 \mathrm{~g} \mathrm{~mol}^{-1}\right)$ : C, 42.45; H, 8.31; exp.: C, 43.26; H, 8.73.

4.2.15 Dendrimer (14). Data for 14: NMR (DMSO- $\left.d_{6}\right):{ }^{1} \mathrm{H}$ (299.99 MHz): $\delta-0.09\left(\mathrm{~s}, 12 \mathrm{H}, \mathrm{Si}^{1} \mathrm{CH}_{3}\right),-0.02\left(\mathrm{~s}, 48 \mathrm{H}, \mathrm{Si}^{2} \mathrm{CH}_{3}\right)$, 0.50-0.65 (m, 64H, $\mathrm{Si}^{0} \mathrm{CH}_{2}, \mathrm{CH}_{2} \mathrm{Si}^{1} \mathrm{CH}_{2} \mathrm{CH}_{2} \mathrm{CH}_{2} \mathrm{Si}^{2} \mathrm{CH}_{2}$ ), 1.13 (dt, $\left.{ }^{3} J_{\mathrm{HP}}=18.0 \mathrm{~Hz},{ }^{3} J_{\mathrm{HH}}=7.6 \mathrm{~Hz}, 48 \mathrm{H}, \mathrm{CH}_{3}\right), 1.25-1.34(\mathrm{~m}, 24 \mathrm{H}$, $\left.\mathrm{Si}^{0} \mathrm{CH}_{2} \mathrm{CH}_{2} \mathrm{CH}_{2} \mathrm{Si}^{1} \mathrm{CH}_{2} \mathrm{CH}_{2}\right)$, 1.43-1.53 (m, 16H, $\mathrm{Si}^{2} \mathrm{CH}_{2} \mathrm{CH}_{2}-$ $\mathrm{CH}_{2} \mathrm{P}$ ), 1.60-1.67 (m, 16H, $\left.\mathrm{PCH}_{2} \mathrm{CH}_{2} \mathrm{CH}_{2} \mathrm{OH}\right), 2.19-2.32$ (m, $\left.64 \mathrm{H}, \mathrm{CH}_{2} \mathrm{P}\right), 3.48\left(\mathrm{q},{ }^{3} J_{\mathrm{HH}}=5.4 \mathrm{~Hz}, 16 \mathrm{H}, \mathrm{CH}_{2} \mathrm{OH}\right), 4.78\left(\mathrm{t},{ }^{3} J_{\mathrm{HH}}=\right.$ $5.4 \mathrm{~Hz}, 8 \mathrm{H}, \mathrm{OH}) .{ }^{13} \mathrm{C}\left\{{ }^{1} \mathrm{H}\right\}(125.70 \mathrm{MHz}): \delta-4.9\left(\mathrm{~s}, \mathrm{Si}^{1} \mathrm{CH}_{3}\right),-3.4$ $\left(\mathrm{s}, \mathrm{Si}^{2} \mathrm{CH}_{3}\right), 5.3\left(\mathrm{~d},{ }^{2} J_{\mathrm{CP}}=5.3 \mathrm{~Hz}, \mathrm{PCH}_{2} \mathrm{CH}_{3}\right), 11.1\left(\mathrm{~d},{ }^{1} J_{\mathrm{CP}}=\right.$ $48.5 \mathrm{~Hz}, \mathrm{CH}_{3} \mathrm{CH}_{2} \mathrm{P}$ ), 14.1 (d, ${ }^{1} J_{\mathrm{CP}}=49.4 \mathrm{~Hz}, \mathrm{PCH}_{2} \mathrm{CH}_{2} \mathrm{CH}_{2} \mathrm{OH}$ ), $15.9\left(\mathrm{~d},{ }^{2} J_{\mathrm{CP}}=4.3 \mathrm{~Hz}, \mathrm{Si}^{2} \mathrm{CH}_{2} \mathrm{CH}_{2} \mathrm{CH}_{2} \mathrm{P}\right), 16.90\left(\mathrm{~d},{ }^{3} J_{\mathrm{CP}}=13.0 \mathrm{~Hz}\right.$, $\mathrm{Si}^{2} \mathrm{CH}_{2} \mathrm{CH}_{2} \mathrm{CH}_{2} \mathrm{P}$ ), 17.1 (s, $\mathrm{Si}^{0} \mathrm{CH}_{2}$ ), 18.0 (s, $\mathrm{Si}^{1} \mathrm{CH}_{2} \mathrm{CH}_{2} \mathrm{CH}_{2} \mathrm{Si}^{2}$ ), 18.3 (s, $\mathrm{Si}^{1} \mathrm{CH}_{2} \mathrm{CH}_{2} \mathrm{CH}_{2} \mathrm{Si}^{2}$ ), 18.5 (s, $\mathrm{Si}^{0} \mathrm{CH}_{2} \mathrm{CH}_{2}$ ), 19.4 (s, $\mathrm{Si}^{1} \mathrm{CH}_{2} \mathrm{CH}_{2} \mathrm{CH}_{2} \mathrm{Si}^{2}$ ), 20.8 (d, ${ }^{1} J_{\mathrm{CP}}=43.4 \mathrm{~Hz}, \mathrm{Si}^{2} \mathrm{CH}_{2} \mathrm{CH}_{2} \mathrm{CH}_{2} \mathrm{P}$ ), $24.1\left(\mathrm{~d},{ }^{2} J_{\mathrm{CP}}=4.3 \mathrm{~Hz}, \mathrm{OHCH}_{2} \mathrm{CH}_{2}\right), 60.4\left(\mathrm{~d},{ }^{3} J_{\mathrm{CP}}=15.5 \mathrm{~Hz}\right.$, $\left.\mathrm{OHCH}_{2}\right),\left(\mathrm{Si}^{0} \mathrm{CH}_{2} \mathrm{CH}_{2} \mathrm{CH}_{2}\right.$ was not detected). ${ }^{29} \mathrm{Si}\left\{{ }^{1} \mathrm{H}\right\}(59.60$ $\mathrm{MHz}): \delta 0.84\left(\mathrm{~s}, \mathrm{Si}^{0}\right), 1.08\left(\mathrm{~s}, \mathrm{Si}^{1}\right), 2.48\left(\mathrm{~d},{ }^{4} J_{\mathrm{SiP}}=2.5 \mathrm{~Hz}, \mathrm{Si}^{2}\right) .{ }^{31} \mathrm{P}$ $\left\{{ }^{1} \mathrm{H}\right\}(121.44 \mathrm{MHz}): \delta$ 42.61. HRMS $\left(\mathrm{C}_{136} \mathrm{H}_{316} \mathrm{O}_{8} \mathrm{Si}_{13} \mathrm{I}_{8}\right):\left(\mathrm{ESI}^{+}\right) \mathrm{m} / z$ : $\left[\mathrm{M}-2 \mathrm{I}^{-}\right]^{2+}$ calcd for $\mathrm{C}_{136} \mathrm{H}_{316} \mathrm{O}_{8} \mathrm{Si}_{13} \mathrm{I}_{6}: 1726.6756$ found: 1726.6756, $\left[\mathrm{M}-3 \mathrm{I}^{-}\right]^{3+}$ calcd for $\mathrm{C}_{136} \mathrm{H}_{316} \mathrm{O}_{8} \mathrm{Si}_{13} \mathrm{I}_{5}: 1108.8154$ found: 1108.8152, $\left[\mathrm{M}-4 \mathrm{I}^{-}\right]^{4+}$ calcd for $\mathrm{C}_{136} \mathrm{H}_{316} \mathrm{O}_{8} \mathrm{Si}_{13} \mathrm{I}_{4}$ : 799.8853 found: 799.8849, $\left[\mathrm{M}-5 \mathrm{I}^{-}\right]^{5+}$ calcd for $\mathrm{C}_{136} \mathrm{H}_{316} \mathrm{O}_{8} \mathrm{Si}_{13} \mathrm{I}_{3}$ : 614.5272 found: $614.5272,\left[\mathrm{M}-6 \mathrm{I}^{-}\right]^{6+}$ calcd for $\mathrm{C}_{136} \mathrm{H}_{316} \mathrm{O}_{8} \mathrm{Si}_{13} \mathrm{I}_{2}$ : 490.9551 found: $490.9552,\left[\mathrm{M}-7 \mathrm{I}^{-}\right]^{7+}$ calcd for $\mathrm{C}_{136} \mathrm{H}_{316} \mathrm{O}_{8} \mathrm{Si}_{13} \mathrm{I}$ : 402.6894 found: 402.6888 . 
4.2.16 Dendrimer (15). Data for 15: NMR (DMSO- $\left.d_{6}\right):{ }^{1} \mathrm{H}$ (499.99 MHz): $\delta-0.10\left(\mathrm{~s}, 36 \mathrm{H}, \mathrm{Si}^{1,2} \mathrm{CH}_{3}\right),-0.03\left(\mathrm{~s}, 96 \mathrm{H}, \mathrm{Si}^{3} \mathrm{CH}_{3}\right.$ ), 0.51-0.57 (m, 112H, $\left.\mathrm{Si}^{0} \mathrm{CH}_{2}, \mathrm{CH}_{2} \mathrm{Si}^{1} \mathrm{CH}_{2}, \mathrm{CH}_{2} \mathrm{Si}^{2} \mathrm{CH}_{2} \mathrm{CH}_{2} \mathrm{CH}_{2} \mathrm{Si}^{3}\right)$, 0.61-0.64 (m, 32H, Si $\left.{ }^{3} \mathrm{CH}_{2} \mathrm{CH}_{2} \mathrm{CH}_{2} \mathrm{P}\right), 1.13\left(\mathrm{dt},{ }^{3} J_{\mathrm{HP}}=15.4 \mathrm{~Hz}\right.$, $\left.{ }^{3} J_{\mathrm{HH}}=7.4 \mathrm{~Hz}, \quad 96 \mathrm{H}, \quad \mathrm{CH}_{3}\right), 1.26-1.33(\mathrm{~m}, \quad 56 \mathrm{H}$, $\left.\mathrm{CH}_{2} \mathrm{CH}_{2} \mathrm{Si}^{1} \mathrm{CH}_{2} \mathrm{CH}_{2} \mathrm{CH}_{2} \mathrm{Si}^{2} \mathrm{CH}_{2} \mathrm{CH}_{2}\right)$, 1.46-1.52 (m, $32 \mathrm{H}$, $\mathrm{Si}^{3} \mathrm{CH}_{2} \mathrm{CH}_{2} \mathrm{CH}_{2} \mathrm{P}$ ), 1.60-1.68 (m, 32H, $\mathrm{CH}_{2} \mathrm{CH}_{2} \mathrm{OH}$ ), 2.22-2.31 $\left(\mathrm{m}, 128 \mathrm{H}, \mathrm{CH}_{2} \mathrm{P}\right), 3.47-3.50\left(\mathrm{~m}, 32 \mathrm{H}, \mathrm{CH}_{2} \mathrm{OH}\right), 4.77$ (br s, $16 \mathrm{H}$, $\mathrm{OH}) .{ }^{13} \mathrm{C}\left\{{ }^{1} \mathrm{H}\right\}(125.70 \mathrm{MHz}): \delta-4.9\left(\mathrm{~s}, \mathrm{Si}^{1,2} \mathrm{CH}_{3}\right),-3.4(\mathrm{~s}$, $\left.\mathrm{Si}^{3} \mathrm{CH}_{3}\right), 5.4\left(\mathrm{~d},{ }^{2} J_{\mathrm{CP}}=4.4 \mathrm{~Hz}, \mathrm{PCH}_{2} \mathrm{CH}_{3}\right), 11.2\left(\mathrm{~d},{ }^{1} J_{\mathrm{CP}}=48.8 \mathrm{~Hz}\right.$, $\mathrm{CH}_{3} \mathrm{CH}_{2} \mathrm{P}$ ), 14.2 (d, $\left.{ }^{1} J_{\mathrm{CP}}=47.9 \mathrm{~Hz}, \mathrm{PCH}_{2} \mathrm{CH}_{2} \mathrm{CH}_{2} \mathrm{OH}\right), 16.0$ (d, $\left.{ }^{2} J_{\mathrm{CP}}=4.4 \mathrm{~Hz}, \mathrm{Si}^{3} \mathrm{CH}_{2} \mathrm{CH}_{2} \mathrm{CH}_{2} \mathrm{P}\right), 16.90\left(\mathrm{~d},{ }^{3} J_{\mathrm{CP}}=12.7 \mathrm{~Hz}\right.$, $\mathrm{Si}^{3} \mathrm{CH}_{2} \mathrm{CH}_{2} \mathrm{CH}_{2} \mathrm{P}$ ), 18.0 (s, $\mathrm{Si}^{2} \mathrm{CH}_{2} \mathrm{CH}_{2} \mathrm{CH}_{2} \mathrm{Si}^{3}$ ), 18.2 (s, $\mathrm{Si}^{1} \mathrm{CH}_{2}-$ $\mathrm{CH}_{2} \mathrm{CH}_{2} \mathrm{Si}^{2}$ ), 18.3 (s, $\mathrm{Si}^{2} \mathrm{CH}_{2} \mathrm{CH}_{2} \mathrm{CH}_{2} \mathrm{Si}^{3}$ ), 18.4 (s, $\mathrm{Si}^{1} \mathrm{CH}_{2} \mathrm{CH}_{2}-$ $\mathrm{CH}_{2} \mathrm{Si}^{2}$ ), 19.5 (s, $\mathrm{Si}^{2} \mathrm{CH}_{2} \mathrm{CH}_{2} \mathrm{CH}_{2} \mathrm{Si}^{3}$ ), 20.9 (d, ${ }^{1} J_{\mathrm{CP}}=43.3 \mathrm{~Hz}$, $\mathrm{Si}^{3} \mathrm{CH}_{2} \mathrm{CH}_{2} \mathrm{CH}_{2} \mathrm{P}$ ), 24.1 (d, ${ }^{2} \mathrm{JP}_{\mathrm{CP}}=4.3 \mathrm{~Hz}, \mathrm{OHCH}_{2} \mathrm{CH}_{2} \mathrm{CH}_{2} \mathrm{P}$ ), 60.4 (d, $\left.{ }^{3} J_{\mathrm{CP}}=15.5 \mathrm{~Hz}, \mathrm{OHCH} \mathrm{H}_{2}\right),\left(\mathrm{Si}^{0} \mathrm{CH}_{2} \mathrm{CH}_{2} \mathrm{CH}_{2}\right.$ were overlap or not detected). ${ }^{29} \mathrm{Si}\left\{{ }^{1} \mathrm{H}\right\}(99.31 \mathrm{MHz}): \delta 0.74\left(\mathrm{~s}, \mathrm{Si}^{0}\right), 1.04\left(\mathrm{~s}, \mathrm{Si}^{1,2}\right), 1.53$ $\left(\mathrm{d},{ }^{4} J_{\mathrm{SiP}}=2.2 \mathrm{~Hz}, \mathrm{Si}^{3}\right) \cdot{ }^{31} \mathrm{P}\left\{{ }^{1} \mathrm{H}\right\}(121.44 \mathrm{MHz}): \delta$ 42.57. HRMS $\left(\mathrm{C}_{288} \mathrm{H}_{668} \mathrm{O}_{16} \mathrm{P}_{16} \mathrm{Si}_{29} \mathrm{I}_{16}\right)$ : $\left(\mathrm{ESI}^{+}\right) \mathrm{m} / \mathrm{z}:\left[\mathrm{M}-3 \mathrm{I}^{-}\right]^{3+}$ calcd for $\mathrm{C}_{288^{-}}$ $\mathrm{H}_{668} \mathrm{O}_{16} \mathrm{P}_{16} \mathrm{Si}_{29} \mathrm{I}_{13}: 2449.2736$ found: 2449.2686 , $\left[\mathrm{M}-4 \mathrm{I}^{-}\right]^{4+}$ calcd for $\mathrm{C}_{288} \mathrm{H}_{668} \mathrm{O}_{16} \mathrm{P}_{16} \mathrm{Si}_{29} \mathrm{I}_{12}$ : 1805.2290 found: 1805.2277 , [M - $\left.5 \mathrm{I}^{-}\right]^{5+}$ calcd for $\mathrm{C}_{288} \mathrm{H}_{668} \mathrm{O}_{16} \mathrm{P}_{16} \mathrm{Si}_{29} \mathrm{I}_{11}$ : 1418.8022 found: 1418.8014, $\left[\mathrm{M}-6 \mathrm{I}^{-}\right]^{6+}$ calcd for $\mathrm{C}_{288} \mathrm{H}_{668} \mathrm{O}_{16} \mathrm{P}_{16} \mathrm{Si}_{29} \mathrm{I}_{10}$ : 1161.1843 found: 1161.1835, $\left[\mathrm{M}-7 \mathrm{I}^{-}\right]^{7+}$ calcd for $\mathrm{C}_{288} \mathrm{H}_{668^{-}}$ $\mathrm{O}_{16} \mathrm{P}_{16} \mathrm{Si}_{29} \mathrm{I}_{9}$ : 977.1715 found: 977.1711, $\left[\mathrm{M}-8 \mathrm{I}^{-}\right]^{8+}$ calcd for $\mathrm{C}_{288} \mathrm{H}_{668} \mathrm{O}_{16} \mathrm{P}_{16} \mathrm{Si}_{29} \mathrm{I}_{8}$ : 839.1620 found: 839.1614, $\left[\mathrm{M}-9 \mathrm{I}^{-}\right]^{9+}$ calcd for $\mathrm{C}_{288} \mathrm{H}_{668} \mathrm{O}_{16} \mathrm{P}_{16} \mathrm{Si}_{29} \mathrm{I}_{7}$ : 731.8212 found: 731.8220, [M $\left.10 \mathrm{I}^{-}\right]^{10+}$ calcd for $\mathrm{C}_{288} \mathrm{H}_{668} \mathrm{O}_{16} \mathrm{P}_{16} \mathrm{Si}_{29} \mathrm{I}_{6}$ : 645.9486 found: 645.9441, $\left[\mathrm{M}-11 \mathrm{I}^{-}\right]^{11+}$ calcd for $\mathrm{C}_{288} \mathrm{H}_{668} \mathrm{O}_{16} \mathrm{P}_{16} \mathrm{Si}_{29} \mathrm{I}_{5}: 575.6891$ found: 575.6874 .

4.2.17 Dendrimer (16). Data for 16: NMR (DMSO- $d_{6}$ ): ${ }^{1} \mathrm{H}$ (499.99 MHz): $\delta-0.02\left(\mathrm{~s}, 24 \mathrm{H}, \mathrm{Si}^{1} \mathrm{CH}_{3}\right), 0.53-0.57(\mathrm{~m}, 16 \mathrm{H}$, $\left.\mathrm{Si}^{0} \mathrm{CH}_{2} \mathrm{CH}_{2} \mathrm{CH}_{2}\right), 0.59-0.63\left(\mathrm{~m}, 8 \mathrm{H}, \mathrm{Si}^{1} \mathrm{CH}_{2} \mathrm{CH}_{2} \mathrm{CH}_{2} \mathrm{P}\right), 0.92(\mathrm{t}$, $\left.{ }^{3} J_{\mathrm{HH}}=7.1 \mathrm{~Hz}, 36 \mathrm{H}, \mathrm{CH}_{3}\right), 1.27-1.33\left(\mathrm{~m}, 8 \mathrm{H}, \mathrm{Si}^{0} \mathrm{CH}_{2} \mathrm{CH}_{2} \mathrm{CH}_{2}\right)$, 1.39-1.49 (m, 56H, $\left.\mathrm{Si}^{1} \mathrm{CH}_{2} \mathrm{CH}_{2} \mathrm{CH}_{2} \mathrm{PCH}_{2} \mathrm{CH}_{2} \mathrm{CH}_{2}\right), 2.17-2.23(\mathrm{~m}$, $\left.32 \mathrm{H}, \mathrm{CH}_{2} \mathrm{P}\right) .{ }^{13} \mathrm{C}\left\{{ }^{1} \mathrm{H}\right\}(125.70 \mathrm{MHz}): \delta-35\left(\mathrm{~s}, \mathrm{Si}^{1} \mathrm{CH}_{3}\right), 13.3(\mathrm{~s}$, $\mathrm{CH}_{2} \mathrm{CH}_{3}$ ), 15.9 (d, ${ }^{2} J_{\mathrm{CP}}=4.5 \mathrm{~Hz}, \mathrm{Si}^{1} \mathrm{CH}_{2} \mathrm{CH}_{2} \mathrm{CH}_{2} \mathrm{P}$ ), 16.8 (d, ${ }^{3} J_{\mathrm{CP}}$ $\left.=13.0 \mathrm{~Hz}, \mathrm{Si}^{1} \mathrm{CH}_{2} \mathrm{CH}_{2} \mathrm{CH}_{2} \mathrm{P}\right), 17.0\left(\mathrm{~s}, \mathrm{Si}^{0} \mathrm{CH}_{2}\right), 17.3\left(\mathrm{~d},{ }^{1} J_{\mathrm{CP}}=\right.$ $47.3 \mathrm{~Hz}, \mathrm{PCH}_{2} \mathrm{CH}_{2} \mathrm{CH}_{2} \mathrm{CH}_{3}$ ), 18.1 (s, $\mathrm{Si}^{0} \mathrm{CH}_{2} \mathrm{CH}_{2}$ ), 19.4 (s, $\mathrm{Si}^{0} \mathrm{CH}_{2} \mathrm{CH}_{2} \mathrm{CH}_{2}$ ), 21.3 (d, ${ }^{1} J_{\mathrm{CP}}=44.7 \mathrm{~Hz}, \mathrm{Si}^{1} \mathrm{CH}_{2} \mathrm{CH}_{2} \mathrm{CH}_{2} \mathrm{P}$ ), 22.7 (d, $\left.{ }^{2} J_{\mathrm{CP}}=4.3 \mathrm{~Hz}, \mathrm{CH}_{3} \mathrm{CH}_{2} \mathrm{CH}_{2} \mathrm{CH}_{2} \mathrm{P}\right), 23.3\left(\mathrm{~d},{ }^{3} J_{\mathrm{CP}}=15.4 \mathrm{~Hz}\right.$, $\left.\mathrm{CH}_{3} \mathrm{CH}_{2}\right) .{ }^{29} \mathrm{Si}\left\{{ }^{1} \mathrm{H}\right\}(99.31 \mathrm{MHz}): \delta 0.67\left(\mathrm{~s}, \mathrm{Si}^{0}\right), 1.61\left(\mathrm{~d},{ }^{4} J_{\mathrm{SiP}}=\right.$ $\left.2.5 \mathrm{~Hz}, \quad \mathrm{Si}^{1}\right) .{ }^{31} \mathrm{P} \quad\left\{{ }^{1} \mathrm{H}\right\} \quad(202.35 \quad \mathrm{MHz}): \quad \delta$ 32.75. HRMS $\left(\mathrm{C}_{80} \mathrm{H}_{180} \mathrm{P}_{4} \mathrm{Si}_{5} \mathrm{I}_{4}\right):\left(\mathrm{ESI}^{+}\right) \mathrm{m} / \mathrm{z}:\left[\mathrm{M}-\mathrm{I}^{-}\right]^{+}$calcd for $\mathrm{C}_{80} \mathrm{H}_{180} \mathrm{P}_{4} \mathrm{Si}_{5} \mathrm{I}_{3}$ : 1786.9036 found: 1786.9038, $\left[\mathrm{M}-2 \mathrm{I}^{-}\right]^{2+}$ calcd for $\mathrm{C}_{80} \mathrm{H}_{180} \mathrm{P}_{4} \mathrm{Si}_{5} \mathrm{I}_{2}$ : 829.9992 found: 829.9985 , $\left[\mathrm{M}-3 \mathrm{I}^{-}\right]^{3+}$ calcd for $\mathrm{C}_{80} \mathrm{H}_{180} \mathrm{P}_{4} \mathrm{Si}_{5} \mathrm{I}: \quad 511.0311$ found: 511.0317, $\left[\mathrm{M}-4 \mathrm{I}^{-}\right]^{4+}$ $\mathrm{C}_{80} \mathrm{H}_{180} \mathrm{P}_{4} \mathrm{Si}_{5}$ : 351.5461 found: 351.5461.

4.2.18 Dendrimer (17). Data for 17: NMR (DMSO- $\left.d_{6}\right):{ }^{1} \mathrm{H}$ (499.99 MHz): $\delta-0.09$ (s, $\left.12 \mathrm{H}, \mathrm{Si}^{1} \mathrm{CH}_{3}\right),-0.03$ (s, 48H, $\mathrm{Si}^{2} \mathrm{CH}_{3}$ ), 0.51-0.56 (m, 48H, $\mathrm{Si}^{0} \mathrm{CH}_{2}, \mathrm{CH}_{2} \mathrm{Si}^{1} \mathrm{CH}_{2} \mathrm{CH}_{2} \mathrm{CH}_{2}$ ), 0.60-0.63 (m, $\left.16 \mathrm{H}, \mathrm{Si}^{2} \mathrm{CH}_{2} \mathrm{CH}_{2} \mathrm{CH}_{2} \mathrm{P}\right), 0.92\left(\mathrm{t},{ }^{3} \mathrm{~J}_{\mathrm{HH}}=7.1 \mathrm{~Hz}, 72 \mathrm{H}, \mathrm{CH}_{3}\right), 1.28-$ $1.32\left(\mathrm{~m}, 24 \mathrm{H}, \mathrm{CH}_{2} \mathrm{CH}_{2} \mathrm{Si}^{1} \mathrm{CH}_{2} \mathrm{CH}_{2}\right), 1.39-1.47(\mathrm{~m}, 112 \mathrm{H}$, $\mathrm{Si}^{2} \mathrm{CH}_{2} \mathrm{CH}_{2} \mathrm{CH}_{2} \mathrm{P}, \mathrm{CH}_{2} \mathrm{CH}_{2} \mathrm{CH}_{3}$ ), 2.19-2.25 (m, 64H, $\left.\mathrm{CH}_{2} \mathrm{P}\right) .{ }^{13} \mathrm{C}$ $\left\{{ }^{1} \mathrm{H}\right\}(125.70 \mathrm{MHz}): \delta-4.9\left(\mathrm{~s}, \mathrm{Si}^{1} \mathrm{CH}_{3}\right),-3.4\left(\mathrm{~s}, \mathrm{Si}^{2} \mathrm{CH}_{3}\right), 13.3(\mathrm{~s}$,
$\mathrm{CH}_{2} \mathrm{CH}_{3}$ ), $16.0\left(\mathrm{~d},{ }^{2} J_{\mathrm{CP}}=3.8 \mathrm{~Hz}, \mathrm{Si}^{2} \mathrm{CH}_{2} \mathrm{CH}_{2} \mathrm{CH}_{2} \mathrm{P}\right), 16.8\left(\mathrm{~d},{ }^{3} J_{\mathrm{CP}}\right.$ $\left.=12.8 \mathrm{~Hz}, \mathrm{Si}^{2} \mathrm{CH}_{2} \mathrm{CH}_{2} \mathrm{CH}_{2} \mathrm{P}\right), 17.1\left(\mathrm{~s}, \mathrm{Si}^{0} \mathrm{CH}_{2}\right), 17.4\left(\mathrm{~d},{ }^{1} J_{\mathrm{CP}}=\right.$ $47.4 \mathrm{~Hz}, \mathrm{PCH}_{2} \mathrm{CH}_{2} \mathrm{CH}_{2} \mathrm{CH}_{3}$ ), $18.0\left(\mathrm{~s}, \mathrm{Si}^{1} \mathrm{CH}_{2} \mathrm{CH}_{2} \mathrm{CH}_{2} \mathrm{Si}^{2}\right), 18.2$ (s, $\mathrm{Si}^{0} \mathrm{CH}_{2} \mathrm{CH}_{2}$ ), $18.3\left(\mathrm{~s}, \mathrm{Si}^{1} \mathrm{CH}_{2} \mathrm{CH}_{2} \mathrm{CH}_{2} \mathrm{Si}^{2}\right), 18.5$ (s, $\mathrm{Si}^{0} \mathrm{CH}_{2} \mathrm{CH}_{2}-$ $\mathrm{CH}_{2}$ ), 19.4 (s, $\mathrm{Si}^{1} \mathrm{CH}_{2} \mathrm{CH}_{2} \mathrm{CH}_{2} \mathrm{Si}^{2}$ ), $21.4\left(\mathrm{~d},{ }^{1} J_{\mathrm{CP}}=44.3 \mathrm{~Hz}\right.$, $\mathrm{Si}^{2} \mathrm{CH}_{2} \mathrm{CH}_{2} \mathrm{CH}_{2} \mathrm{P}$ ), 22.7 (d, ${ }^{2} J_{\mathrm{CP}}=4.4 \mathrm{~Hz}, \mathrm{CH}_{3} \mathrm{CH}_{2} \mathrm{CH}_{2} \mathrm{CH}_{2} \mathrm{P}$ ), $23.3\left(\mathrm{~d},{ }^{3} \mathrm{~J}_{\mathrm{CP}}=15.5 \mathrm{~Hz}, \mathrm{CH}_{3} \mathrm{CH}_{2}\right) .{ }^{29} \mathrm{Si}$ (inept) $\left\{{ }^{1} \mathrm{H}\right\}(99.31 \mathrm{MHz})$ : $\delta 0.79\left(\mathrm{~s}, \mathrm{Si}^{0}\right), 1.03\left(\mathrm{~s}, \mathrm{Si}^{1}\right), 1.56\left(\mathrm{~d},{ }^{4} J_{\mathrm{SiP}}=2.5 \mathrm{~Hz}, \mathrm{Si}^{2}\right) .{ }^{31} \mathrm{P}\left\{{ }^{1} \mathrm{H}\right\}$ (202.37 MHz): $\delta$ 32.71. HRMS $\left(\mathrm{C}_{176} \mathrm{H}_{396} \mathrm{I}_{8} \mathrm{P}_{8} \mathrm{Si}_{13}\right):\left(\mathrm{ESI}^{+}\right) \mathrm{m} / \mathrm{z}:[\mathrm{M}-$ $\left.2 \mathrm{I}^{-}\right]^{2+}$ calcd for $\mathrm{C}_{176} \mathrm{H}_{396} \mathrm{I}_{6} \mathrm{P}_{8} \mathrm{Si}_{13}: 1943.5098$ found: 1943.5091, $\left[\mathrm{M}-3 \mathrm{I}^{-}\right]^{3+}$ calcd for $\mathrm{C}_{176} \mathrm{H}_{396} \mathrm{I}_{5} \mathrm{P}_{8} \mathrm{Si}_{13}$ : 1253.3715 found: 1253.3708, $\left[\mathrm{M}-4 \mathrm{I}^{-}\right]^{4+}$ calcd for $\mathrm{C}_{176} \mathrm{H}_{396} \mathrm{I}_{4} \mathrm{P}_{8} \mathrm{Si}_{13}$ : 908.3024 found: 908.3029, $\left[\mathrm{M}-5 \mathrm{I}^{-}\right]^{5+}$ calcd for $\mathrm{C}_{176} \mathrm{H}_{396} \mathrm{I}_{3} \mathrm{P}_{8} \mathrm{Si}_{13}$ : 701.2609 found: 701.2603, $\left[\mathrm{M}-6 \mathrm{I}^{-}\right]^{6+}$ calcd for $\mathrm{C}_{176} \mathrm{H}_{396} \mathrm{I}_{2} \mathrm{P}_{8} \mathrm{Si}_{13}$ : 563.2332 found: 563.2317, $\left[\mathrm{M}-7 \mathrm{I}^{-}\right]^{7+}$ calcd for $\mathrm{C}_{176} \mathrm{H}_{396} \mathrm{IP}_{8} \mathrm{Si}_{13}$ : 464.6420 found: 464.6411 .

4.2.19 Dendrimer (18). Data for 18: NMR $\left(\mathrm{CD}_{3} \mathrm{CN}\right):{ }^{1} \mathrm{H}$ (499.99 MHz): $\delta-0.07$ (s, $\left.12 \mathrm{H}, \mathrm{Si}^{1} \mathrm{CH}_{3}\right),-0.06\left(\mathrm{~s}, 24 \mathrm{H}, \mathrm{Si}^{2} \mathrm{CH}_{3}\right.$ ), 0.01 (s, 96H, $\mathrm{Si}^{3} \mathrm{CH}_{3}$ ), 0.55-0.62 (m, $112 \mathrm{H}, \mathrm{Si}^{0} \mathrm{CH}_{2}, \mathrm{CH}_{2} \mathrm{Si}^{1} \mathrm{CH}_{2}$, $\left.\mathrm{CH}_{2} \mathrm{Si}^{2} \mathrm{CH}_{2} \mathrm{CH}_{2} \mathrm{CH}_{2} \mathrm{Si}^{3}\right), 0.66-0.70\left(\mathrm{~m}, 32 \mathrm{H}, \mathrm{Si}^{3} \mathrm{CH}_{2} \mathrm{CH}_{2} \mathrm{CH}_{2} \mathrm{P}\right)$, $0.96\left(\mathrm{t},{ }^{3} J_{\mathrm{HH}}=7.1 \mathrm{~Hz}, 144 \mathrm{H}, \mathrm{CH}_{3}\right), 1.31-1.39(\mathrm{~m}, 56 \mathrm{H}$, $\left.\mathrm{CH}_{2} \mathrm{CH}_{2} \mathrm{Si}^{1} \mathrm{CH}_{2} \mathrm{CH}_{2} \mathrm{CH}_{2} \mathrm{Si}^{2} \mathrm{CH}_{2} \mathrm{CH}_{2}\right), \quad 1.44-1.56(\mathrm{~m}, \quad 224 \mathrm{H}$, $\mathrm{Si}^{3} \mathrm{CH}_{2} \mathrm{CH}_{2} \mathrm{CH}_{2} \mathrm{P}, \mathrm{CH}_{2} \mathrm{CH}_{2} \mathrm{CH}_{3}$ ), 2.20-2.28 (m, $\left.128 \mathrm{H}, \mathrm{CH}_{2} \mathrm{P}\right) .{ }^{13} \mathrm{C}$ $\left\{{ }^{1} \mathrm{H}\right\}(125.70 \mathrm{MHz}): \delta-4.1\left(\mathrm{~s}, \mathrm{Si}^{1,2} \mathrm{CH}_{3}\right),-2.8\left(\mathrm{~s}, \mathrm{Si}^{3} \mathrm{CH}_{3}\right), 13.8$ (s, $\mathrm{CH}_{2} \mathrm{CH}_{3}$ ), 17.6 (d, ${ }^{2} J_{\mathrm{CP}}=4.9 \mathrm{~Hz}, \mathrm{Si}^{3} \mathrm{CH}_{2} \mathrm{CH}_{2} \mathrm{CH}_{2} \mathrm{P}$ ), 18.1 (d, ${ }^{3} J_{\mathrm{CP}}=13.2 \mathrm{~Hz}, \mathrm{Si}^{3} \mathrm{CH}_{2} \mathrm{CH}_{2} \mathrm{CH}_{2} \mathrm{P}$ ), 18.5 (br s, $\mathrm{Si}^{0} \mathrm{CH}_{2}$ ), 19.3 (d, $\left.{ }^{1} J_{\mathrm{CP}}=47.5 \mathrm{~Hz}, \mathrm{PCH}_{2} \mathrm{CH}_{2} \mathrm{CH}_{2} \mathrm{CH}_{3}\right),\left(\mathrm{Si}^{0} \mathrm{CH}_{2} \mathrm{CH}_{2}\right.$ overlap), 19.4 (s, $\mathrm{Si}^{2} \mathrm{CH}_{2} \mathrm{CH}_{2} \mathrm{CH}_{2} \mathrm{Si}^{3}$ ), $19.5\left(\mathrm{~s}, \mathrm{Si}^{1} \mathrm{CH}_{2} \mathrm{CH}_{2} \mathrm{CH}_{2} \mathrm{Si}^{2}\right), 19.6\left(\mathrm{~s}, \mathrm{Si}^{2} \mathrm{CH}_{2}-\right.$ $\mathrm{CH}_{2} \mathrm{CH}_{2} \mathrm{Si}^{3}$ ), $19.8\left(\mathrm{~s}, \mathrm{Si}^{1} \mathrm{CH}_{2} \mathrm{CH}_{2} \mathrm{CH}_{2} \mathrm{Si}^{2}\right), 20.0\left(\mathrm{~s}, \mathrm{Si}^{0} \mathrm{CH}_{2} \mathrm{CH}_{2}-\right.$ $\mathrm{CH}_{2}$ ), 20.7 (s, $\left.\mathrm{Si}^{2} \mathrm{CH}_{2} \mathrm{CH}_{2} \mathrm{CH}_{2} \mathrm{Si}^{3}\right), 23.3\left(\mathrm{~d},{ }^{1} J_{\mathrm{CP}}=44.8 \mathrm{~Hz}\right.$, $\mathrm{Si}^{3} \mathrm{CH}_{2} \mathrm{CH}_{2} \mathrm{CH}_{2} \mathrm{P}$ ), 24.2 (d, ${ }^{2} J_{\mathrm{CP}}=4.5 \mathrm{~Hz}, \mathrm{CH}_{3} \mathrm{CH}_{2} \mathrm{CH}_{2} \mathrm{CH}_{2} \mathrm{P}$ ), $24.6\left(\mathrm{~d},{ }^{3} J_{\mathrm{CP}}=15.4 \mathrm{~Hz}, \mathrm{CH}_{3} \mathrm{CH}_{2}\right) .{ }^{29} \mathrm{Si}\left\{{ }^{1} \mathrm{H}\right\}(59.60 \mathrm{MHz}): \delta 0.72(\mathrm{~s}$, $\left.\mathrm{Si}^{0}\right), 0.99\left(\mathrm{~s}, \mathrm{Si}^{1,2}\right), 1.55\left(\mathrm{~d},{ }^{4} J_{\mathrm{SiP}}=2.5 \mathrm{~Hz}, \mathrm{Si}^{3}\right) .{ }^{31} \mathrm{P}\left\{{ }^{1} \mathrm{H}\right\}(202.37$ $\mathrm{MHz}): \delta$ 33.55. HRMS $\left(\mathrm{C}_{368} \mathrm{H}_{828} \mathrm{I}_{16} \mathrm{P}_{16} \mathrm{Si}_{29}\right):\left(\mathrm{ESI}^{+}\right) \mathrm{m} / \mathrm{z}:[\mathrm{M}-$ $\left.4 \mathrm{I}^{-}\right]^{4+}$ calcd for $\mathrm{C}_{368} \mathrm{H}_{828} \mathrm{I}_{12} \mathrm{P}_{16} \mathrm{Si}_{29}: 2021.8131$ found: 2021.8132 , $\left[\mathrm{M}-5 \mathrm{I}^{-}\right]^{5+}$ calcd for $\mathrm{C}_{368} \mathrm{H}_{828} \mathrm{I}_{11} \mathrm{P}_{16} \mathrm{Si}_{29}$ : 1592.0695 found: 1592.0695, $\left[\mathrm{M}-6 \mathrm{I}^{-}\right]^{6+}$ calcd for $\mathrm{C}_{368} \mathrm{H}_{828} \mathrm{I}_{10} \mathrm{P}_{16} \mathrm{Si}_{29}: 1305.5737$ found: $1305.5729,\left[\mathrm{M}-7 \mathrm{I}^{-}\right]^{7+} \mathrm{C}_{368} \mathrm{H}_{828} \mathrm{I}_{9} \mathrm{P}_{16} \mathrm{Si}_{29}$ : 1100.9338 found: $1100.9317,\left[\mathrm{M}-8 \mathrm{I}^{-}\right]^{8+} \mathrm{C}_{368} \mathrm{H}_{828} \mathrm{I}_{8} \mathrm{P}_{16} \mathrm{Si}_{29}$ : 947.4540 found: $947.4557,\left[\mathrm{M}-9 \mathrm{I}^{-}\right]^{9+} \mathrm{C}_{368} \mathrm{H}_{828} \mathrm{I}_{7} \mathrm{P}_{16} \mathrm{Si}_{29}$ : 828.0807 found: 828.0775, $\left[\mathrm{M}-10 \mathrm{I}^{-}\right]^{10+} \mathrm{C}_{368} \mathrm{H}_{828} \mathrm{I}_{6} \mathrm{P}_{16} \mathrm{Si}_{29}$ : 732.5822 found: 732.5795 .

4.2.20 Dendrimer (22). Data for 22: NMR (DMSO- $\left.d_{6}\right):{ }^{1} \mathrm{H}$ $(299.99 \mathrm{MHz}): \delta-0.16\left(\mathrm{~s}, 24 \mathrm{H}, \mathrm{Si}^{1} \mathrm{CH}_{3}\right), 0.40-0.45(\mathrm{~m}, 16 \mathrm{H}$, $\left.\mathrm{Si}^{0} \mathrm{CH}_{2} \mathrm{CH}_{2} \mathrm{CH}_{2}\right), 0.65-0.70\left(\mathrm{~m}, 8 \mathrm{H}, \mathrm{CH}_{2} \mathrm{CH}_{2} \mathrm{CH}_{2} \mathrm{P}\right), 1.16-1.19(\mathrm{~m}$, $\left.8 \mathrm{H}, \mathrm{Si}^{0} \mathrm{CH}_{2} \mathrm{CH}_{2} \mathrm{CH}_{2}\right), 1.46-1.52\left(\mathrm{~m}, 8 \mathrm{H}, \mathrm{CH}_{2} \mathrm{CH}_{2} \mathrm{P}\right), 3.35-3.44(\mathrm{~m}$, $\left.8 \mathrm{H}, \mathrm{CH}_{2} \mathrm{P}\right), 3.87\left(\mathrm{~s}, 36 \mathrm{H}, \mathrm{OCH}_{3}\right), 7.25-7.29(\mathrm{~m}, 24 \mathrm{H} \mathrm{CH}), 7.63-$ $7.70(\mathrm{~m}, 24 \mathrm{H}, \mathrm{CH}) .{ }^{13} \mathrm{C}\left\{{ }^{1} \mathrm{H}\right\}(75.44 \mathrm{MHz}): \delta-3.6\left(\mathrm{~s}, \mathrm{Si}^{1} \mathrm{CH}_{3}\right), 16.6$ $\left(\mathrm{d},{ }^{3} J_{\mathrm{CP}}=13.9 \mathrm{~Hz}, \mathrm{CH}_{2} \mathrm{CH}_{2} \mathrm{CH}_{2} \mathrm{P}\right), 16.7\left(\mathrm{~s}, \mathrm{Si}^{0} \mathrm{CH}_{2}\right), 16.9\left(\mathrm{~d},{ }^{2} J_{\mathrm{CP}}=\right.$ $3.9 \mathrm{~Hz}, \mathrm{CH}_{2} \mathrm{CH}_{2} \mathrm{P}$ ), 18.0 (s, $\mathrm{Si}^{0} \mathrm{CH}_{2} \mathrm{CH}_{2}$ ), $19.2\left(\mathrm{~s}, \mathrm{Si}^{0} \mathrm{CH}_{2} \mathrm{CH}_{2} \mathrm{CH}_{2}\right.$ ), $24.6\left(\mathrm{~d},{ }^{1} J_{\mathrm{CP}}=49.1 \mathrm{~Hz}, \mathrm{PCH}_{2}\right), 55.9\left(\mathrm{~s}, \mathrm{OCH}_{3}\right), 109.5\left(\mathrm{~d},{ }^{1} J_{\mathrm{CP}}=\right.$ 93.1 Hz, CP), 115.8 (d, $\left.{ }^{3} J_{\mathrm{CP}}=13.5 \mathrm{~Hz}, C \mathrm{HCHCP}\right), 135.4\left(\mathrm{~d},{ }^{2} J_{\mathrm{CP}}=\right.$ $11.6 \mathrm{~Hz}, C \mathrm{HCP}), 163.9$ (d, $\left.{ }^{4} J_{\mathrm{CP}}=2.9 \mathrm{~Hz}, C_{\text {ipso }}\right) .{ }^{29} \mathrm{Si}\left\{{ }^{1} \mathrm{H}\right\}(59.60$ $\mathrm{MHz}): \delta 0.70\left(\mathrm{~s}, \mathrm{Si}^{0}\right), 1.53\left(\mathrm{~d},{ }^{4} J_{\mathrm{SiP}}=2.7 \mathrm{~Hz}, \mathrm{Si}^{1}\right) .{ }^{31} \mathrm{P}\left\{{ }^{1} \mathrm{H}\right\}(121.44$ $\mathrm{MHz}): \delta$ 26.47. HRMS $\left(\mathrm{C}_{80} \mathrm{H}_{180} \mathrm{Cl}_{4} \mathrm{P}_{4} \mathrm{Si}_{5}\right):\left(\mathrm{ESI}^{+}\right) \mathrm{m} / \mathrm{z}:\left[\mathrm{M}-\mathrm{Cl}^{-}\right]^{+}$ calcd for $\mathrm{C}_{80} \mathrm{H}_{180} \mathrm{Cl}_{3} \mathrm{P}_{4} \mathrm{Si}_{5}: 1512.0940$ found: 1512.0932, [M $\left.2 \mathrm{Cl}^{-}\right]^{2+}$ calcd for $\mathrm{C}_{80} \mathrm{H}_{180} \mathrm{Cl}_{2} \mathrm{P}_{4} \mathrm{Si}_{5}$ : 738.5621 found: 738.5627, [M 
$\left.-3 \mathrm{Cl}^{-}\right]^{3+}$ calcd for $\mathrm{C}_{80} \mathrm{H}_{180} \mathrm{ClP}_{4} \mathrm{Si}_{5}: 480.3858$ found: 480.3859 , $\left[\mathrm{M}-4 \mathrm{Cl}^{-}\right]^{4+}$ calcd for $\mathrm{C}_{80} \mathrm{H}_{180} \mathrm{P}_{4} \mathrm{Si}_{5}: 351.5466$ found: 351.5471 .

4.2.21 Dendrimer (23). Data for 23: NMR (DMSO- $d_{6}$ ): ${ }^{1} \mathrm{H}$ (499.99 MHz): $\delta-0.21$ (s, $\left.12 \mathrm{H}, \mathrm{Si}^{1} \mathrm{CH}_{3}\right),-0.18\left(48 \mathrm{H}, \mathrm{Si}^{2} \mathrm{CH}_{3}\right)$, 0.39-0.44 (m, 48H, Si $\left.{ }^{0} \mathrm{CH}_{2}, \mathrm{CH}_{2} \mathrm{Si}^{1} \mathrm{CH}_{2} \mathrm{CH}_{2} \mathrm{CH}_{2}\right), 0.65-0.68$ (m, $\left.16 \mathrm{H}, \mathrm{CH}_{2} \mathrm{CH}_{2} \mathrm{CH}_{2} \mathrm{P}\right), 1.14-1.22\left(\mathrm{~m}, 24 \mathrm{H}, \mathrm{CH}_{2} \mathrm{CH}_{2} \mathrm{Si}^{1} \mathrm{CH}_{2} \mathrm{CH}_{2}\right)$, 1.44-1.50 (m, $\left.16 \mathrm{H}, \mathrm{CH}_{2} \mathrm{CH}_{2} \mathrm{P}\right), 3.38-3.42\left(\mathrm{~m}, 16 \mathrm{H}, \mathrm{CH}_{2} \mathrm{P}\right), 3.85$ (s, $\left.72 \mathrm{H}, \mathrm{OCH}_{3}\right), 7.24-7.27(\mathrm{~m}, 48 \mathrm{H} \mathrm{CH}), 7.63-7.67(\mathrm{~m}, 48 \mathrm{H}, \mathrm{CH}) .{ }^{13} \mathrm{C}$ $\left\{{ }^{1} \mathrm{H}\right\}(125.70 \mathrm{MHz}): \delta-5.1\left(\mathrm{~s}, \mathrm{Si}^{1} \mathrm{CH}_{3}\right),-3.6\left(\mathrm{~s}, \mathrm{Si}^{2} \mathrm{CH}_{3}\right), 16.5$ (d, $\left.{ }^{3} J_{\mathrm{CP}}=13.4 \mathrm{~Hz}, \mathrm{CH}_{2} \mathrm{CH}_{2} \mathrm{CH}_{2} \mathrm{P}\right), 16.9\left(\mathrm{~d},{ }^{2} J_{\mathrm{CP}}=4.4 \mathrm{~Hz}, \mathrm{CH}_{2} \mathrm{CH}_{2} \mathrm{P}\right)$, $17.0\left(\mathrm{~s}, \mathrm{Si}^{0} \mathrm{CH}_{2}\right), 17.9$ (s, $\left.\mathrm{Si}^{1} \mathrm{CH}_{2} \mathrm{CH}_{2} \mathrm{CH}_{2} \mathrm{Si}^{2}\right), 18.1\left(\mathrm{~s}, \mathrm{Si}^{1} \mathrm{CH}_{2}-\right.$ $\left.\mathrm{CH}_{2} \mathrm{CH}_{2} \mathrm{Si}^{2}\right),\left(\mathrm{Si}^{0} \mathrm{CH}_{2} \mathrm{CH}_{2}\right.$ overlap), $18.4\left(\mathrm{~s}, \mathrm{Si}^{0} \mathrm{CH}_{2} \mathrm{CH}_{2} \mathrm{CH}_{2}\right), 19.2$ (s, $\mathrm{Si}^{1} \mathrm{CH}_{2} \mathrm{CH}_{2} \mathrm{CH}_{2} \mathrm{Si}^{2}$ ), 24.6 (d, $\left.{ }^{1} J_{\mathrm{CP}}=49.2 \mathrm{~Hz}, \mathrm{CH}_{2} \mathrm{P}\right), 55.9$ (s, $\left.\mathrm{OCH}_{3}\right), 109.5\left(\mathrm{~d},{ }^{1} J_{\mathrm{CP}}=93.1 \mathrm{~Hz}, \mathrm{CP}\right), 115.8\left(\mathrm{~d},{ }^{3} J_{\mathrm{CP}}=13.5 \mathrm{~Hz}\right.$, CHCHCP), 135.4 (d, $\left.{ }^{2} J_{\mathrm{CP}}=11.6 \mathrm{~Hz}, \mathrm{CHCP}\right), 163.9\left(\mathrm{~d},{ }^{4} J_{\mathrm{CP}}=\right.$ $\left.3.2 \mathrm{~Hz}, C_{\mathrm{ipso}}\right) .{ }^{29} \mathrm{Si}\left\{{ }^{1} \mathrm{H}\right\}(99.31 \mathrm{MHz}): \delta 0.7\left(\mathrm{~s}, \mathrm{Si}^{0}\right), 0.95\left(\mathrm{~s}, \mathrm{Si}^{1}\right)$, $1.43\left(\mathrm{~d},{ }^{4} J_{\mathrm{SiP}}=2.9 \mathrm{~Hz}, \mathrm{Si}^{2}\right) .{ }^{31} \mathrm{P}\left\{{ }^{1} \mathrm{H}\right\}(202.37 \mathrm{MHz}): \delta 20.59$. HRMS $\left(\mathrm{C}_{176} \mathrm{H}_{396} \mathrm{Cl}_{8} \mathrm{P}_{8} \mathrm{Si}_{13}\right)$ : $\left(\mathrm{ESI}^{+}\right) \mathrm{m} / z$ : $\left[\mathrm{M}-3 \mathrm{Cl}^{-}\right]^{3+}$ calcd for $\mathrm{C}_{176^{-}}$ $\mathrm{H}_{396} \mathrm{Cl}_{5} \mathrm{P}_{8} \mathrm{Si}_{13}: 1100.8111$ found: $1100.8111,\left[\mathrm{M}-4 \mathrm{Cl}^{-}\right]^{4+}$ calcd for $\mathrm{C}_{176} \mathrm{H}_{396} \mathrm{Cl}_{4} \mathrm{P}_{8} \mathrm{Si}_{13}$ : 816.8661 found: 816.8653, $\left[\mathrm{M}-5 \mathrm{Cl}^{-}\right]^{5+}$ calcd for $\mathrm{C}_{176} \mathrm{H}_{396} \mathrm{Cl}_{3} \mathrm{P}_{8} \mathrm{Si}_{13}$ : 646.2991 found: 646.2989, [M $\left.6 \mathrm{Cl}^{-}\right]^{6+}$ calcd for $\mathrm{C}_{176} \mathrm{H}_{396} \mathrm{Cl}_{2} \mathrm{P}_{8} \mathrm{Si}_{13}: 532.7545$ found: 532.7547 , $\left[\mathrm{M}-7^{-\mathrm{Cl}^{-}}\right]^{7+}$ calcd for $\mathrm{C}_{176} \mathrm{H}_{396} \mathrm{ClP}_{8} \mathrm{Si}_{13}: 451.5083$ found: 451.5086, $\left[\mathrm{M}-8 \mathrm{Cl}^{-}\right]^{8+}$ calcd for $\mathrm{C}_{176} \mathrm{H}_{396} \mathrm{P}_{8} \mathrm{Si}_{13}: 390.6987$ found: 390.6983. Anal. calc. $\mathrm{C}_{248} \mathrm{H}_{348} \mathrm{I}_{8} \mathrm{O}_{24} \mathrm{P}_{8} \mathrm{Si}_{13}$ (5341.54 g $\mathrm{mol}^{-1}$ ): C, 55.76; H, 6.57; exp.: C, 56.22; H, 6.78.

4.2.22 Dendrimer (24). Data for 24: NMR (DMSO- $d_{6}$ ): ${ }^{1} \mathrm{H}$ (499.99 MHz): $\delta-0.20$ (br s, $132 \mathrm{H}, \mathrm{Si}^{1,2,3} \mathrm{CH}_{3}$ ), 0.40 (br s, $\left.112 \mathrm{H}, \quad \mathrm{Si}^{0} \mathrm{CH}_{2}, \quad \mathrm{CH}_{2} \mathrm{Si}^{1} \mathrm{CH}_{2}, \quad \mathrm{CH}_{2} \mathrm{Si}^{2} \mathrm{CH}_{2} \mathrm{CH}_{2} \mathrm{CH}_{2} \mathrm{Si}^{3}\right), \quad 0.68$ (br s, 32H, $\left.\mathrm{CH}_{2} \mathrm{CH}_{2} \mathrm{CH}_{2} \mathrm{P}\right), \quad 1.17 \quad$ (br s, $56 \mathrm{H}$, $\mathrm{CH}_{2} \mathrm{CH}_{2} \mathrm{Si}^{1} \mathrm{CH}_{2} \mathrm{CH}_{2} \mathrm{CH}_{2} \mathrm{Si}^{2} \mathrm{CH}_{2} \mathrm{CH}_{2}$ ), 1.47 (br s, $32 \mathrm{H}, \mathrm{CH}_{2} \mathrm{CH}_{2} \mathrm{P}$ ), $3.42\left(\mathrm{br} \mathrm{s}, 32 \mathrm{H}, \mathrm{CH}_{2} \mathrm{P}\right), 3.83\left(\mathrm{~s}, 144 \mathrm{H}, \mathrm{OCH}_{3}\right), 7.23-7.25(\mathrm{~m}, 96 \mathrm{H}$, $\mathrm{CH}), 7.64-7.68(\mathrm{~m}, 96 \mathrm{H}, \mathrm{CH}) .{ }^{13} \mathrm{C}\left\{{ }^{1} \mathrm{H}\right\}(125.70 \mathrm{MHz}): \delta-5.1(\mathrm{~s}$, $\left.\mathrm{Si}^{1,2} \mathrm{CH}_{3}\right),-3.7\left(\mathrm{~s}, \mathrm{Si}^{3} \mathrm{CH}_{3}\right), 16.5\left(\mathrm{~d},{ }^{3} J_{\mathrm{CP}}=14.0 \mathrm{~Hz}, \mathrm{CH}_{2} \mathrm{CH}_{2}-\right.$ $\left.\mathrm{CH}_{2} \mathrm{P}\right), 16.9\left(\mathrm{~d},{ }^{2} J_{\mathrm{CP}}=4.0 \mathrm{~Hz}, \mathrm{CH}_{2} \mathrm{CH}_{2} \mathrm{P}\right) ; 17.9\left(\mathrm{~s}, \mathrm{Si}^{2} \mathrm{CH}_{2} \mathrm{CH}_{2}-\right.$ $\left.\mathrm{CH}_{2} \mathrm{Si}^{3}\right), 18.1$ (s, $\left.\mathrm{Si}^{1} \mathrm{CH}_{2} \mathrm{CH}_{2} \mathrm{CH}_{2} \mathrm{Si}^{2}\right), 18.3\left(\mathrm{~s}, \mathrm{Si}^{2} \mathrm{CH}_{2} \mathrm{CH}_{2} \mathrm{CH}_{2} \mathrm{Si}^{3}\right)$, $18.6\left(\mathrm{~s}, \mathrm{Si}^{0} \mathrm{CH}_{2} \mathrm{CH}_{2} \mathrm{CH}_{2}\right), 19.2\left(\mathrm{~s}, \mathrm{Si}^{2} \mathrm{CH}_{2} \mathrm{CH}_{2} \mathrm{CH}_{2} \mathrm{Si}^{3}\right), 24.7\left(\mathrm{~d},{ }^{1} \mathrm{~J}_{\mathrm{CP}}\right.$ $\left.=49.6 \mathrm{~Hz}, \mathrm{CH}_{2} \mathrm{P}\right), 55.9\left(\mathrm{~s}, \mathrm{OCH}_{3}\right), 109.5\left(\mathrm{~d},{ }^{1} J_{\mathrm{CP}}=93.2 \mathrm{~Hz}, C \mathrm{P}\right)$, $115.8\left(\mathrm{~d},{ }^{3} J_{\mathrm{CP}}=13.4 \mathrm{~Hz}, C \mathrm{HCHCP}\right), 135.4\left(\mathrm{~d},{ }^{2} J_{\mathrm{CP}}=11.7 \mathrm{~Hz}\right.$, CHCP), 163.9 (d, $\left.{ }^{4} J_{\mathrm{CP}}=3.1 \mathrm{~Hz}, C_{\mathrm{ipso}}\right),\left(\mathrm{Si}^{0} \mathrm{CH}_{2} \mathrm{CH}_{2}\right.$ were not detected or overlap). ${ }^{29} \mathrm{Si}\left\{{ }^{1} \mathrm{H}\right\}$ (inept) (99.31 MHz): $\delta \mathrm{Si}^{0}$ was not detected, $0.92\left(\mathrm{~s}, \mathrm{Si}^{1,2}\right), 1.39\left(\mathrm{~d},{ }^{4} J_{\mathrm{SiP}}=2.9 \mathrm{~Hz}, \mathrm{Si}^{3}\right) .{ }^{31} \mathrm{P}\left\{{ }^{1} \mathrm{H}\right\}$ (202.37 MHz): $\delta$ 20.57. HRMS $\left(\mathrm{C}_{368} \mathrm{H}_{828} \mathrm{Cl}_{16} \mathrm{P}_{16} \mathrm{Si}_{29}\right):\left(\mathrm{ESI}^{+}\right) \mathrm{m} / \mathrm{z}$ : $\left[\mathrm{M}-2 \mathrm{Cl}^{-}\right]^{2+}$ calcd for $\mathrm{C}_{368} \mathrm{H}_{828} \mathrm{Cl}_{14} \mathrm{P}_{16} \mathrm{Si}_{29}$ : 3529.9769 found: 3529.9799, $\left[\mathrm{M}-3 \mathrm{Cl}^{-}\right]^{3+}$ calcd for $\mathrm{C}_{368} \mathrm{H}_{828} \mathrm{Cl}_{13} \mathrm{P}_{16} \mathrm{Si}_{29}$ : 2341.6616 found: 2341.6592, $\left[\mathrm{M}-4 \mathrm{Cl}^{-}\right]^{4+}$ calcd for $\mathrm{C}_{368} \mathrm{H}_{828^{-}}$ $\mathrm{Cl}_{12} \mathrm{P}_{16} \mathrm{Si}_{29}: 1747.2541$ found: $1747.2537,\left[\mathrm{M}-5 \mathrm{Cl}^{-}\right]^{5+}$ calcd for $\mathrm{C}_{368} \mathrm{H}_{828} \mathrm{Cl}_{11} \mathrm{P}_{16} \mathrm{Si}_{29}: 1390.8095$ found: 1390.8097 , $\left[\mathrm{M}-6 \mathrm{Cl}^{-}\right]^{6+}$ calcd for $\mathrm{C}_{368} \mathrm{H}_{828} \mathrm{Cl}_{10} \mathrm{P}_{16} \mathrm{Si}_{29}$ : 1153.0131 found: 1153.0127 , [M $\left.{ }_{7 \mathrm{Cl}^{-}}\right]^{7+}$ calcd for $\mathrm{C}_{368} \mathrm{H}_{828} \mathrm{Cl}_{9} \mathrm{P}_{16} \mathrm{Si}_{29}$ : 983.3014 found: 983.2992, $\left[\mathrm{M}-8 \mathrm{Cl}^{-}\right]^{8+}$ calcd for $\mathrm{C}_{368} \mathrm{H}_{828} \mathrm{Cl}_{8} \mathrm{P}_{16} \mathrm{Si}_{29}: 855.7677$ found: 855.7692, $\left[\mathrm{M}-9 \mathrm{Cl}^{-}\right]^{9+}$ calcd for $\mathrm{C}_{368} \mathrm{H}_{828} \mathrm{Cl}_{7} \mathrm{P}_{16} \mathrm{Si}_{29}$ : 756.9080 found: 756.9035, $\left[\mathrm{M}-10 \mathrm{Cl}^{-}\right]^{10+}$ calcd for $\mathrm{C}_{368} \mathrm{H}_{828} \mathrm{Cl}_{6} \mathrm{P}_{16} \mathrm{Si}_{29}$ : 677.6204 found: 677.6217 .

4.2.23 Dendrimer (28). Data for 28: NMR (DMSO- $\left.d_{6}\right):{ }^{1} \mathrm{H}$ (499.99 MHz): $\delta-0.17\left(\mathrm{~s}, 24 \mathrm{H}, \mathrm{Si}^{1} \mathrm{CH}_{3}\right) ; 0.38-0.43(\mathrm{~m}, 16 \mathrm{H}$, $\mathrm{Si}^{0} \mathrm{CH}_{2} \mathrm{CH}_{2} \mathrm{CH}_{2}$ ), 0.68-0.72 (m, 8H, Si $\left.{ }^{1} \mathrm{CH}_{2} \mathrm{CH}_{2} \mathrm{CH}_{2} \mathrm{P}\right), 1.16-1.18$ (m, 8H, $\left.\mathrm{Si}^{0} \mathrm{CH}_{2} \mathrm{CH}_{2}\right), 1.50-1.52\left(\mathrm{~m}, 8 \mathrm{H}, \mathrm{CH}_{2} \mathrm{CH}_{2} \mathrm{P}\right), 3.61-3.64(\mathrm{~m}$, $\left.8 \mathrm{H}, \mathrm{CH}_{2} \mathrm{P}\right), 7.74-7.90(\mathrm{~m}, 60 \mathrm{H}, \mathrm{CH} P h) .{ }^{13} \mathrm{C}\left\{{ }^{1} \mathrm{H}\right\}(125.70 \mathrm{MHz})$ : $\delta-3.6\left(\mathrm{~s}, \mathrm{Si}^{1} \mathrm{CH}_{3}\right), 16.6\left(\mathrm{~d},{ }^{3} J_{\mathrm{CP}}=13.6 \mathrm{~Hz}, \mathrm{CH}_{2} \mathrm{CH}_{2} \mathrm{CH}_{2} \mathrm{P}\right), 16.7(\mathrm{~s}$, $\left.\mathrm{Si}^{0} \mathrm{CH}_{2}\right), 17.0\left(\mathrm{~d},{ }^{2} J_{\mathrm{CP}}=4.6 \mathrm{~Hz}, \mathrm{CH}_{2} \mathrm{CH}_{2} \mathrm{P}\right), 18.0\left(\mathrm{~s}, \mathrm{Si}^{0} \mathrm{CH}_{2} \mathrm{CH}_{2}\right)$, $19.2\left(\mathrm{~s}, \mathrm{Si}^{0} \mathrm{CH}_{2} \mathrm{CH}_{2} \mathrm{CH}_{2}\right), 23.5\left(\mathrm{~d},{ }^{1} J_{\mathrm{CP}}=46.0 \mathrm{~Hz}, \mathrm{PCH}_{2}\right), 118.5(\mathrm{~d}$, $\left.{ }^{1} J_{\mathrm{CP}}=85.4 \mathrm{~Hz}, C \mathrm{P}\right), 130.2\left(\mathrm{~d},{ }^{3} J_{\mathrm{CP}}=12.4 \mathrm{~Hz}, C \mathrm{HCHCP}\right), 133.5(\mathrm{~d}$, $\left.{ }^{2} J_{\mathrm{CP}}=10.0 \mathrm{~Hz}, \mathrm{CHCP}\right), 134.9$ (d, ${ }^{4} J_{\mathrm{CP}}=3.2 \mathrm{~Hz}$, CHCHCHCP). ${ }^{29} \mathrm{Si}\left\{{ }^{1} \mathrm{H}\right\}(99.31 \mathrm{MHz}): \delta 0.69\left(\mathrm{~s}, \mathrm{Si}^{0}\right), 1.55\left(\mathrm{~d},{ }^{4} J_{\mathrm{SiP}}=2.7 \mathrm{~Hz}, \mathrm{Si}^{1}\right)$. ${ }^{31} \mathrm{P}\left\{{ }^{1} \mathrm{H}\right\}(202.37 \mathrm{MHz}): \delta 22.88$. HRMS: $\mathrm{C}_{104} \mathrm{H}_{132} \mathrm{P}_{4} \mathrm{Si}_{5} \mathrm{I}_{4}\left(\mathrm{ESI}^{+}\right)$: $m / z$ calc. for $\left[\mathrm{C}_{104} \mathrm{H}_{132} \mathrm{P}_{4} \mathrm{Si}_{5} \mathrm{I}_{3}\right]^{+}$calc. 2026.5281 found 2026.5244; $\left[\mathrm{C}_{104} \mathrm{H}_{132} \mathrm{P}_{4} \mathrm{Si}_{5} \mathrm{I}_{2}\right]^{2+} \quad$ calc. 949.8115 found 949.8118; $\left[\mathrm{C}_{104} \mathrm{H}_{132} \mathrm{P}_{4} \mathrm{Si}_{5} \mathrm{I}\right]^{3+} \quad$ calc. 590.9060 found 590.9052 $\left[\mathrm{C}_{104} \mathrm{H}_{132} \mathrm{P}_{4} \mathrm{Si}_{5}\right]^{4+}$ calc. 411.4532 found 411.4533.

4.2.24 Dendrimer (29). Data for 29: NMR (DMSO- $\left.d_{6}\right):{ }^{1} \mathrm{H}$ (499.99 MHz): $\delta-0.20$ (br s, $60 \mathrm{H}, \mathrm{Si}^{1} \mathrm{CH}_{3}, \mathrm{Si}^{2} \mathrm{CH}_{3}$ ), 0.38-0.45 (m, $\left.48 \mathrm{H}, \mathrm{CH}_{2} \mathrm{CH}_{2} \mathrm{CH}_{2} \mathrm{Si}^{1} \mathrm{CH}_{2} \mathrm{CH}_{2} \mathrm{CH}_{2}\right), 0.66-0.70\left(\mathrm{~m}, 16 \mathrm{H}, \mathrm{CH}_{2} \mathrm{CH}_{2}-\right.$ $\left.\mathrm{CH}_{2} \mathrm{P}\right), 1.15-1.21\left(\mathrm{~m}, 24 \mathrm{H}, \mathrm{CH}_{2} \mathrm{CH}_{2} \mathrm{Si}^{1} \mathrm{CH}_{2} \mathrm{CH}_{2}\right), 1.47-1.52(\mathrm{~m}$, $\left.16 \mathrm{H}, \mathrm{CH}_{2} \mathrm{CH}_{2} \mathrm{P}\right), 3.56-3.62\left(\mathrm{~m}, 16 \mathrm{H}, \mathrm{CH}_{2} \mathrm{P}\right), 7.72-7.89(\mathrm{~m}, 120 \mathrm{H}$, $\mathrm{CH} P h) .{ }^{13} \mathrm{C}\left\{{ }^{1} \mathrm{H}\right\}(125.70 \mathrm{MHz}): \delta-5.0\left(\mathrm{~s}, \mathrm{Si}^{1} \mathrm{CH}_{3}\right),-3.6(\mathrm{~s}$, $\left.\mathrm{Si}^{2} \mathrm{CH}_{3}\right), 16.5\left(\mathrm{~d},{ }^{3} J_{\mathrm{CP}}=13.6 \mathrm{~Hz}, \mathrm{CH}_{2} \mathrm{CH}_{2} \mathrm{CH}_{2} \mathrm{P}\right), 16.97\left(\mathrm{~d},{ }^{2} J_{\mathrm{CP}}=\right.$ $\left.4.8 \mathrm{~Hz}, \mathrm{CH}_{2} \mathrm{CH}_{2} \mathrm{P}\right), 17.04\left(\mathrm{~s}, \mathrm{Si}^{0} \mathrm{CH}_{2}\right), 17.9\left(\mathrm{~s}, \mathrm{Si}^{1} \mathrm{CH}_{2} \mathrm{CH}_{2} \mathrm{CH}_{2} \mathrm{Si}^{2}\right)$, $18.1\left(\mathrm{~s}, \quad \mathrm{Si}^{1} \mathrm{CH}_{2} \mathrm{CH}_{2} \mathrm{CH}_{2} \mathrm{Si}^{2}\right), 18.2\left(\mathrm{~s}, \quad \mathrm{Si}^{0} \mathrm{CH}_{2} \mathrm{CH}_{2}\right), 18.4$ (s, $\left.\mathrm{Si}^{0} \mathrm{CH}_{2} \mathrm{CH}_{2} \mathrm{CH}_{2}\right), 19.2\left(\mathrm{~s}, \mathrm{Si}^{1} \mathrm{CH}_{2} \mathrm{CH}_{2} \mathrm{CH}_{2} \mathrm{Si}^{2}\right), 23.5\left(\mathrm{~d},{ }^{1} J_{\mathrm{CP}}=\right.$ $\left.46.2 \mathrm{~Hz}, C_{\mathrm{H}} \mathrm{P}\right), 118.5\left(\mathrm{~d},{ }^{1} J_{\mathrm{CP}}=85.2 \mathrm{~Hz}, C \mathrm{P}\right), 130.2\left(\mathrm{~d},{ }^{3} J_{\mathrm{CP}}=\right.$ $12.4 \mathrm{~Hz}, C \mathrm{HCHCP}), 133.5$ (d, $\left.{ }^{2} J_{\mathrm{CP}}=10.1 \mathrm{~Hz}, C \mathrm{HCP}\right), 134.9$ (d, ${ }^{4} J_{\mathrm{CP}}=3.1 \mathrm{~Hz}$, CHCHCHCP). ${ }^{29} \mathrm{Si}\left\{{ }^{1} \mathrm{H}\right\}(99.31 \mathrm{MHz}): \delta 0.74\left(\mathrm{~s}, \mathrm{Si}^{0}\right)$, $1.00\left(\mathrm{~s}, \mathrm{Si}^{1}\right), 1.52\left(\mathrm{~d},{ }^{4} J_{\mathrm{SiP}}=2.9 \mathrm{~Hz}, \mathrm{Si}^{2}\right) .{ }^{31} \mathrm{P}\left\{{ }^{1} \mathrm{H}\right\}(202.37 \mathrm{MHz})$ : $\delta$ 22.91. HRMS: $\mathrm{C}_{224} \mathrm{H}_{300} \mathrm{P}_{8} \mathrm{Si}_{13} \mathrm{I}_{8} \quad\left(\mathrm{ESI}^{+}\right): \mathrm{m} / z$ calc. for $\left[\mathrm{C}_{224} \mathrm{H}_{300} \mathrm{P}_{8} \mathrm{Si}_{13} \mathrm{I}_{6}\right]^{2+} \quad$ calc. 1943.5098 found 1943.5098; $\left[\mathrm{C}_{224} \mathrm{H}_{300} \mathrm{P}_{8} \mathrm{Si}_{13} \mathrm{I}_{5}\right]^{3+} \quad$ calc. 1253.3715 found 1253.3708; $\left[\mathrm{C}_{224} \mathrm{H}_{300} \mathrm{P}_{8} \mathrm{Si}_{13} \mathrm{I}_{4}\right]^{4+} \quad$ calc. 908.3024 found 908.3029; $\left[\mathrm{C}_{224} \mathrm{H}_{300} \mathrm{P}_{8} \mathrm{Si}_{13} \mathrm{I}_{3}\right]^{5+} \quad$ calc. 701.2609 found 701.2603; $\left[\mathrm{C}_{224} \mathrm{H}_{300} \mathrm{P}_{8} \mathrm{Si}_{13} \mathrm{I}_{2}\right]^{6+}$ calc. 563.2332 found 563.2317; $\left[\mathrm{C}_{224} \mathrm{H}_{300} \mathrm{P}_{8} \mathrm{Si}_{13} \mathrm{I}\right]^{7+}$ calc. 464.6420 found 464.6420 .

4.2.25 Dendrimer (30). Data for 30: NMR (DMSO- $\left.d_{6}\right)$ : ${ }^{1} \mathrm{H}$ (499.99 MHz): $\delta-0.22$ (br s, $\left.132 \mathrm{H}, \mathrm{Si}^{1,2,3} \mathrm{CH}_{3}\right), 0.38-0.46(\mathrm{~m}$, $\left.112 \mathrm{H}, \quad \mathrm{CH}_{2} \mathrm{CH}_{2} \mathrm{CH}_{2} \mathrm{Si}^{1} \mathrm{CH}_{2} \mathrm{CH}_{2} \mathrm{CH}_{2} \mathrm{Si}^{2} \mathrm{CH}_{2} \mathrm{CH}_{2} \mathrm{CH}_{2}\right), \quad 0.67-0.71$ $\left(\mathrm{m}, \quad 32 \mathrm{H}, \quad \mathrm{CH}_{2} \mathrm{CH}_{2} \mathrm{CH}_{2} \mathrm{P}\right), \quad 1.14-1.24 \quad(\mathrm{~m}, \quad 56 \mathrm{H}$, $\left.\mathrm{CH}_{2} \mathrm{CH}_{2} \mathrm{Si}^{1} \mathrm{CH}_{2} \mathrm{CH}_{2} \mathrm{CH}_{2} \mathrm{Si}^{2} \mathrm{CH}_{2} \mathrm{CH}_{2}\right), \quad 1.45-1.52 \quad(\mathrm{~m}, \quad 32 \mathrm{H}$, $\left.\mathrm{CH}_{2} \mathrm{CH}_{2} \mathrm{P}\right), 3.57-3.66\left(\mathrm{~m}, 32 \mathrm{H}, \mathrm{CH}_{2} \mathrm{P}\right), 7.73-7.86(\mathrm{~m}, 240 \mathrm{H}, \mathrm{CH}$ $\mathrm{Ph}) .{ }^{13} \mathrm{C}\left\{{ }^{1} \mathrm{H}\right\}(125.70 \mathrm{MHz}): \delta-5.0\left(\mathrm{~s}, \mathrm{Si}^{1,2} \mathrm{CH}_{3}\right),-3.6\left(\mathrm{~s}, \mathrm{Si}^{3} \mathrm{CH}_{3}\right)$, $16.5\left(\mathrm{~d},{ }^{3} J_{\mathrm{CP}}=13.4 \mathrm{~Hz}, \mathrm{CH}_{2} \mathrm{CH}_{2} \mathrm{CH}_{2} \mathrm{P}\right), 17.0\left(\mathrm{~d},{ }^{2} J_{\mathrm{CP}}=4.0 \mathrm{~Hz}\right.$, $\left.\mathrm{CH}_{2} \mathrm{CH}_{2} \mathrm{P}\right), 17.9\left(\mathrm{~s}, \mathrm{Si}^{2} \mathrm{CH}_{2} \mathrm{CH}_{2} \mathrm{CH}_{2} \mathrm{Si}^{3}\right),\left(\mathrm{Si}^{0} \mathrm{CH}_{2} \mathrm{CH}_{2} \mathrm{CH}_{2}\right.$ were not detected or overlap), 18.07 (s, $\mathrm{Si}^{1} \mathrm{CH}_{2} \mathrm{CH}_{2} \mathrm{CH}_{2} \mathrm{Si}^{2}$ ), 18.12 (s, $\left.\mathrm{Si}^{2} \mathrm{CH}_{2} \mathrm{CH}_{2} \mathrm{CH}_{2} \mathrm{Si}^{3}\right), 18.3\left(\mathrm{~s}, \mathrm{Si}^{1} \mathrm{CH}_{2} \mathrm{CH}_{2} \mathrm{CH}_{2} \mathrm{Si}^{2}\right), 19.2\left(\mathrm{~s}, \mathrm{Si}^{2} \mathrm{CH}_{2}-\right.$ $\left.\mathrm{CH}_{2} \mathrm{CH}_{2} \mathrm{Si}^{3}\right), 23.5\left(\mathrm{~d},{ }^{1} J_{\mathrm{CP}}=46.1 \mathrm{~Hz}, \mathrm{CH}_{2} \mathrm{P}\right), 118.5\left(\mathrm{~d},{ }^{1} J_{\mathrm{CP}}=\right.$ $85.2 \mathrm{~Hz}, C \mathrm{P}), 130.2\left(\mathrm{~d},{ }^{3} J_{\mathrm{CP}}=12.3 \mathrm{~Hz}, \mathrm{CHCHCP}\right), 133.6\left(\mathrm{~d},{ }^{2} J_{\mathrm{CP}}=\right.$ $10.1 \mathrm{~Hz}$, CHCP), 134.9 (d, $\left.{ }^{4} J_{\mathrm{CP}}=2.9 \mathrm{~Hz}, \mathrm{CHCHCHCP}\right) .{ }^{29} \mathrm{Si}\left\{{ }^{1} \mathrm{H}\right\}$ (59.60 MHz): $\delta \mathrm{Si}^{0}$ was not detected, $0.97\left(\mathrm{~s}, \mathrm{Si}^{1}, \mathrm{Si}^{2}\right), 1.47$. (d, $\left.{ }^{4} J_{\mathrm{SiP}}=3.0 \mathrm{~Hz}, \mathrm{Si}^{3}\right) .{ }^{31} \mathrm{P}\left\{{ }^{1} \mathrm{H}\right\}(202.37 \mathrm{MHz}): \delta$ 22.87. HRMS: $\mathrm{C}_{464} \mathrm{H}_{636} \mathrm{P}_{16} \mathrm{Si}_{29} \mathrm{I}_{16}\left(\mathrm{ESI}^{+}\right): \mathrm{m} / \mathrm{z}$ calc. for $\left[\mathrm{C}_{464} \mathrm{H}_{636} \mathrm{P}_{16} \mathrm{Si}_{29} \mathrm{I}_{13}\right]^{3+}$ 3057.8860 found 3057.8863; $\quad\left[\mathrm{C}_{464} \mathrm{H}_{636} \mathrm{P}_{16} \mathrm{Si}_{29} \mathrm{I}_{12}\right]^{4+}$ calc. 2261.6882 found 2261.6880; $\quad\left[\mathrm{C}_{464} \mathrm{H}_{636} \mathrm{P}_{16} \mathrm{Si}_{29} \mathrm{I}_{11}\right]^{5+}$ calc. 1783.9696 found $1783.9639 ; \quad\left[\mathrm{C}_{464} \mathrm{H}_{636} \mathrm{P}_{16} \mathrm{Si}_{29} \mathrm{I}_{10}\right]^{6+}$ calc. 1465.4905 found 1465.4898; $\quad\left[\mathrm{C}_{464} \mathrm{H}_{636} \mathrm{P}_{16} \mathrm{Si}_{29} \mathrm{I}_{9}\right]^{7+}$ calc.1238.0054 found 1238.0038; $\left[\mathrm{C}_{464} \mathrm{H}_{636} \mathrm{P}_{16} \mathrm{Si}_{29} \mathrm{I}_{8}\right]^{8+}$ calc. 1067.3916 found 1067.3900; $\left[\mathrm{C}_{464} \mathrm{H}_{636} \mathrm{P}_{16} \mathrm{Si}_{29} \mathrm{I}_{7}\right]^{9+}$ calc. 934.6920 
found 934.6933; $\left[\mathrm{C}_{464} \mathrm{H}_{636} \mathrm{P}_{16} \mathrm{Si}_{29} \mathrm{I}_{6}\right]^{10+} 828.5323$ found 828.5305; $\left[\mathrm{C}_{464} \mathrm{H}_{636} \mathrm{P}_{16} \mathrm{Si}_{29} \mathrm{I}_{5}\right]^{11+} \quad$ calc. 741.6744 found 741.6765; $\left[\mathrm{C}_{464} \mathrm{H}_{636} \mathrm{P}_{16} \mathrm{Si}_{29} \mathrm{I}_{4}\right]^{12+} \quad$ calc. 669.2927 found 669.2976; $\left[\mathrm{C}_{464} \mathrm{H}_{636} \mathrm{P}_{16} \mathrm{Si}_{29} \mathrm{I}_{3}\right]^{13+}$ calc. 608.0467 found 608.0451 .

Dendrimers 19-21, 25-27, 31-33 were prepared according to similar procedure. A respective iodo derivative was converted to chloro derivative by ion exchange on AMBERLYST A-21 with methanol as the mobile phase. In all cases yields are in range between $98-100 \%$.

4.2.26 Dendrimer (19). Data for 19: NMR $\left(\mathrm{CD}_{3} \mathrm{CN}\right):{ }^{1} \mathrm{H}$ (499.99 MHz): $\delta 0.00\left(\mathrm{~s}, 24 \mathrm{H}, \mathrm{Si}^{1} \mathrm{CH}_{3}\right), 0.56-0.61(\mathrm{~m}, 16 \mathrm{H}$, $\left.\mathrm{Si}^{0} \mathrm{CH}_{2} \mathrm{CH}_{2} \mathrm{CH}_{2}\right), 0.64-0.67\left(\mathrm{~m}, 8 \mathrm{H}, \mathrm{Si}^{1} \mathrm{CH}_{2} \mathrm{CH}_{2} \mathrm{CH}_{2} \mathrm{P}\right), 0.95(\mathrm{t}$, $\left.{ }^{3} J_{\mathrm{HH}}=7.1 \mathrm{~Hz}, 36 \mathrm{H}, \mathrm{CH}_{3}\right), 1.31-1.38\left(\mathrm{~m}, 8 \mathrm{H}, \mathrm{Si}^{0} \mathrm{CH}_{2} \mathrm{CH}_{2} \mathrm{CH}_{2}\right)$, 1.42-1.55 (m, 56H, $\mathrm{Si}^{1} \mathrm{CH}_{2} \mathrm{CH}_{2} \mathrm{CH}_{2} \mathrm{PCH}_{2} \mathrm{CH}_{2} \mathrm{CH}_{2}$ ), 2.14-2.21 (m, $\left.32 \mathrm{H}, \mathrm{CH}_{2} \mathrm{P}\right) .{ }^{13} \mathrm{C}\left\{{ }^{1} \mathrm{H}\right\}(125.70 \mathrm{MHz}): \delta-3.2\left(\mathrm{~s}, \mathrm{Si}^{1} \mathrm{CH}_{3}\right), 13.7(\mathrm{~d}$, $\left.{ }^{4} J_{\mathrm{CP}}=0.9 \mathrm{~Hz}, \mathrm{CH}_{2} \mathrm{CH}_{3}\right), 17.4\left(\mathrm{~d},{ }^{2} J_{\mathrm{CP}}=4.7 \mathrm{~Hz}, \mathrm{Si}^{1} \mathrm{CH}_{2} \mathrm{CH}_{2} \mathrm{CH}_{2} \mathrm{P}\right)$, $18.0\left(\mathrm{~d},{ }^{3} J_{\mathrm{CP}}=12.9 \mathrm{~Hz}, \mathrm{Si}^{1} \mathrm{CH}_{2} \mathrm{CH}_{2} \mathrm{CH}_{2} \mathrm{P}\right), 18.2\left(\mathrm{~s}, \mathrm{Si}^{0} \mathrm{CH}_{2}\right), 19.1$ (d, ${ }^{1} J_{\mathrm{CP}}=47.8 \mathrm{~Hz}, \mathrm{PCH}_{2} \mathrm{CH}_{2} \mathrm{CH}_{2} \mathrm{CH}_{3}$ ), $19.4\left(\mathrm{~s}, \mathrm{Si}^{0} \mathrm{CH}_{2} \mathrm{CH}_{2}\right), 20.6$ (s, $\mathrm{Si}^{0} \mathrm{CH}_{2} \mathrm{CH}_{2} \mathrm{CH}_{2}$ ), 23.0 (d, ${ }^{1} J_{\mathrm{CP}}=44.6 \mathrm{~Hz}, \mathrm{Si}^{1} \mathrm{CH}_{2} \mathrm{CH}_{2} \mathrm{CH}_{2} \mathrm{P}$ ), $24.0\left(\mathrm{~d},{ }^{2} J_{\mathrm{CP}}=4.3 \mathrm{~Hz}, \mathrm{CH}_{3} \mathrm{CH}_{2} \mathrm{CH}_{2} \mathrm{CH}_{2} \mathrm{P}\right), 24.5$ (d, ${ }^{3} J_{\mathrm{CP}}=15.3 \mathrm{~Hz}$, $\left.\mathrm{CH}_{3} \mathrm{CH}_{2}\right) .{ }^{29} \mathrm{Si}\left\{{ }^{1} \mathrm{H}\right\}(99.31 \mathrm{MHz}): \delta 0.60\left(\mathrm{~s}, \mathrm{Si}^{0}\right), 1.58\left(\mathrm{~d},{ }^{4} J_{\mathrm{SiP}}=\right.$ $\left.2.4 \mathrm{~Hz}, \mathrm{Si}^{1}\right) .{ }^{31} \mathrm{P}\left\{{ }^{1} \mathrm{H}\right\}(121.41 \mathrm{MHz}): \delta$ 33.60. HRMS $\left(\mathrm{C}_{116} \mathrm{H}_{156}\right.$ $\left.\mathrm{P}_{4} \mathrm{Si}_{5} \mathrm{I}_{4} \mathrm{O}_{12}\right):\left(\mathrm{ESI}^{+}\right) \mathrm{m} / \mathrm{z}:\left[\mathrm{M}-\mathrm{I}^{-}\right]^{+}$calcd for $\mathrm{C}_{116} \mathrm{H}_{156} \mathrm{P}_{4} \mathrm{Si}_{5} \mathrm{I}_{3} \mathrm{O}_{12}$ : 2386.6549 found: 2386.6554, $\left[\mathrm{M}-2 \mathrm{I}^{-}\right]^{2+}$ calcd for $\mathrm{C}_{116} \mathrm{H}_{156} \mathrm{P}_{4^{-}}$ $\mathrm{Si}_{5} \mathrm{I}_{2} \mathrm{O}_{12}: 1129.8749$ found: $1129.8755,\left[\mathrm{M}-3 \mathrm{I}^{-}\right]^{3+}$ calcd for $\mathrm{C}_{116} \mathrm{H}_{156} \mathrm{P}_{4} \mathrm{Si}_{5} \mathrm{I}_{3} \mathrm{O}_{12}$ : 710.9483 found: $710.9478,\left[\mathrm{M}-4 \mathrm{I}^{-}\right]^{4+}$ calcd for $\mathrm{C}_{116} \mathrm{H}_{156} \mathrm{P}_{4} \mathrm{Si}_{5} \mathrm{O}_{12}$ : 501.4849 found: 501.4853 .

4.2.27 Dendrimer (20). Data for 20: NMR $\left(\mathrm{CD}_{3} \mathrm{CN}\right):{ }^{1} \mathrm{H}$ (499.99 MHz): $\delta-0.07\left(\mathrm{~s}, 12 \mathrm{H}, \mathrm{Si}^{1} \mathrm{CH}_{3}\right),-0.01\left(\mathrm{~s}, 48 \mathrm{H}, \mathrm{Si}^{2} \mathrm{CH}_{3}\right.$ ), 0.53-0.60 (m, 48H, Si ${ }^{0} \mathrm{CH}_{2}, \mathrm{CH}_{2} \mathrm{Si}^{1} \mathrm{CH}_{2} \mathrm{CH}_{2} \mathrm{CH}_{2}$ ), 0.64-0.67 (m, $\left.16 \mathrm{H}, \mathrm{Si}^{2} \mathrm{CH}_{2} \mathrm{CH}_{2} \mathrm{CH}_{2} \mathrm{P}\right), 0.94\left(\mathrm{t},{ }^{3} J_{\mathrm{HH}}=7.1 \mathrm{~Hz}, 72 \mathrm{H}, \mathrm{CH}_{3}\right), 1.31-$ $1.36\left(\mathrm{~m}, 24 \mathrm{H}, \mathrm{CH}_{2} \mathrm{CH}_{2} \mathrm{Si}^{1} \mathrm{CH}_{2} \mathrm{CH}_{2}\right), 1.42-1.54(\mathrm{~m}, 112 \mathrm{H}$, $\mathrm{Si}^{2} \mathrm{CH}_{2} \mathrm{CH}_{2} \mathrm{CH}_{2} \mathrm{P}, \mathrm{CH}_{2} \mathrm{CH}_{2} \mathrm{CH}_{3}$ ), 2.17-2.27 (m, 64H, $\left.\mathrm{CH}_{2} \mathrm{P}\right) .{ }^{13} \mathrm{C}$ $\left\{{ }^{1} \mathrm{H}\right\}(125.70 \mathrm{MHz}): \delta-4.4\left(\mathrm{~s}, \mathrm{Si}^{1} \mathrm{CH}_{3}\right),-3.1\left(\mathrm{~s}, \mathrm{Si}^{2} C \mathrm{H}_{3}\right), 13.7$ (s, $\mathrm{CH}_{2} \mathrm{CH}_{3}$ ), 17.4 (d, $\left.{ }^{2} \mathrm{~J}_{\mathrm{CP}}=4.7 \mathrm{~Hz}, \mathrm{Si}^{2} \mathrm{CH}_{2} \mathrm{CH}_{2} \mathrm{CH}_{2} \mathrm{P}\right), 18.0$ (d, ${ }^{3} J_{\mathrm{CP}}$ $\left.=12.9 \mathrm{~Hz}, \mathrm{Si}^{2} \mathrm{CH}_{2} \mathrm{CH}_{2} \mathrm{CH}_{2} \mathrm{P}\right), 18.42\left(\mathrm{~s}, \mathrm{Si}^{0} \mathrm{CH}_{2}\right), 19.1\left(\mathrm{~d},{ }^{1} J_{\mathrm{CP}}=\right.$ $47.6 \mathrm{~Hz}, \mathrm{PCH}_{2} \mathrm{CH}_{2} \mathrm{CH}_{2} \mathrm{CH}_{3}$ ), 19.3 (s, $\mathrm{Si}^{1} \mathrm{CH}_{2} \mathrm{CH}_{2} \mathrm{CH}_{2} \mathrm{Si}^{2}$ ), 19.6 (s, $\mathrm{Si}^{1} \mathrm{CH}_{2} \mathrm{CH}_{2} \mathrm{CH}_{2} \mathrm{Si}^{2}, \mathrm{Si}^{0} \mathrm{CH}_{2} \mathrm{CH}_{2}$ ), 19.8 (s, $\mathrm{Si}^{0} \mathrm{CH}_{2} \mathrm{CH}_{2} \mathrm{CH}_{2}$ ), 20.6 (s, $\mathrm{Si}^{1} \mathrm{CH}_{2} \mathrm{CH}_{2} \mathrm{CH}_{2} \mathrm{Si}^{2}$ ), 23.1 (d, ${ }^{1} J_{\mathrm{CP}}=44.5 \mathrm{~Hz}, \mathrm{Si}^{2} \mathrm{CH}_{2} \mathrm{CH}_{2} \mathrm{CH}_{2} \mathrm{P}$ ), $24.1\left(\mathrm{~d},{ }^{2} J_{\mathrm{CP}}=4.6 \mathrm{~Hz}, \mathrm{CH}_{3} \mathrm{CH}_{2} \mathrm{CH}_{2} \mathrm{CH}_{2} \mathrm{P}\right), 24.6\left(\mathrm{~d},{ }^{3} J_{\mathrm{CP}}=15.7 \mathrm{~Hz}\right.$, $\left.\mathrm{CH}_{3} \mathrm{CH}_{2}\right) .{ }^{29} \mathrm{Si}\left\{{ }^{1} \mathrm{H}\right\}(59.60 \mathrm{MHz}): \delta 0.74\left(\mathrm{~s}, \mathrm{Si}^{0}\right), 0.98\left(\mathrm{~s}, \mathrm{Si}^{1}\right), 1.54$ $\left(\mathrm{d},{ }^{4} J_{\mathrm{SiP}}=2.5 \mathrm{~Hz}, \mathrm{Si}^{2}\right) .{ }^{31} \mathrm{P}\left\{{ }^{1} \mathrm{H}\right\}(202.37 \mathrm{MHz}): \delta$ 32.47. HRMS $\left(\mathrm{C}_{248} \mathrm{H}_{348} \mathrm{P}_{8} \mathrm{O}_{24} \mathrm{Si}_{13} \mathrm{I}_{8}\right):\left(\mathrm{ESI}^{+}\right) \mathrm{m} / \mathrm{z}:\left[\mathrm{M}-3 \mathrm{I}^{-}\right]^{3+}$ calcd for $\mathrm{C}_{248^{-}}$ $\mathrm{H}_{348} \mathrm{P}_{8} \mathrm{O}_{24} \mathrm{Si}_{13} \mathrm{I}_{5}$ : 1653.5399 found: 1653.5380, $\left[\mathrm{M}-4 \mathrm{I}^{-}\right]^{4+}$ calcd for $\mathrm{C}_{248} \mathrm{H}_{348} \mathrm{P}_{8} \mathrm{O}_{24} \mathrm{Si}_{13} \mathrm{I}_{4}$ : 1208.4287 found: 1208.4270, [M - $\left.5 \mathrm{I}^{-}\right]^{5+}$ calcd for $\mathrm{C}_{248} \mathrm{H}_{348} \mathrm{P}_{8} \mathrm{O}_{24} \mathrm{Si}_{13} \mathrm{I}_{3}$ : 941.3619 found: 941.3607, $\left[\mathrm{M}-6 \mathrm{I}^{-}\right]^{6+}$ calcd for $\mathrm{C}_{248} \mathrm{H}_{348} \mathrm{P}_{8} \mathrm{O}_{24} \mathrm{Si}_{13} \mathrm{I}_{2}: 763.3174$ found: 763.3156, $\left[\mathrm{M}-7 \mathrm{I}^{-}\right]^{7+}$ calcd for $\mathrm{C}_{248} \mathrm{H}_{348} \mathrm{P}_{8} \mathrm{O}_{24} \mathrm{Si}_{13} \mathrm{I}$ : 636.1428 found: 636.1405, $\left[\mathrm{M}-8 \mathrm{I}^{-}\right]^{8+}$ calcd for $\mathrm{C}_{248} \mathrm{H}_{348} \mathrm{P}_{8} \mathrm{O}_{24} \mathrm{Si}_{13}: 540.7618$ found: 540.7615 .

4.2.28 Dendrimer (21). Data for 21: NMR $\left(\mathrm{CD}_{3} \mathrm{CN}\right):{ }^{1} \mathrm{H}$ (499.99 MHz): $\delta-0.08$ (s, $\left.12 \mathrm{H}, \mathrm{Si}^{1} \mathrm{CH}_{3}\right),-0.06\left(\mathrm{~s}, 24 \mathrm{H}, \mathrm{Si}^{2} \mathrm{CH}_{3}\right.$ ), 0.00 (s, 96H, $\mathrm{Si}^{3} \mathrm{CH}_{3}$ ), 0.54-0.59 (m, $112 \mathrm{H}, \mathrm{Si}^{0} \mathrm{CH}_{2}, \mathrm{CH}_{2} \mathrm{Si}^{1} \mathrm{CH}_{2}$, $\left.\mathrm{CH}_{2} \mathrm{Si}^{2} \mathrm{CH}_{2} \mathrm{CH}_{2} \mathrm{CH}_{2} \mathrm{Si}^{3}\right), 0.64-0.68\left(\mathrm{~m}, 32 \mathrm{H}, \mathrm{Si}^{3} \mathrm{CH}_{2} \mathrm{CH}_{2} \mathrm{CH}_{2} \mathrm{P}\right)$, $0.95\left(\mathrm{t},{ }^{3} J_{\mathrm{HH}}=7.1 \mathrm{~Hz}, 144 \mathrm{H}, \mathrm{CH}_{3}\right), 1.32-1.37(\mathrm{~m}, 56 \mathrm{H}$, $\left.\mathrm{CH}_{2} \mathrm{CH}_{2} \mathrm{Si}^{1} \mathrm{CH}_{2} \mathrm{CH}_{2} \mathrm{CH}_{2} \mathrm{Si}^{2} \mathrm{CH}_{2} \mathrm{CH}_{2}\right), \quad 1.44-1.55$ (m, $224 \mathrm{H}$, $\mathrm{Si}^{3} \mathrm{CH}_{2} \mathrm{CH}_{2} \mathrm{CH}_{2} \mathrm{P}, \mathrm{CH}_{2} \mathrm{CH}_{2} \mathrm{CH}_{3}$ ), 2.21-2.30 (m, $\left.128 \mathrm{H}, \mathrm{CH}_{2} \mathrm{P}\right) .{ }^{13} \mathrm{C}$ $\left\{{ }^{1} \mathrm{H}\right\}(125.70 \mathrm{MHz}): \delta-4.2\left(\mathrm{~s}, \mathrm{Si}^{1,2} \mathrm{CH}_{3}\right),-2.9\left(\mathrm{~s}, \mathrm{Si}^{3} \mathrm{CH}_{3}\right), 13.8$ $\left(\mathrm{s}, \mathrm{CH}_{2} \mathrm{CH}_{3}\right.$ ), 17.5 (d, ${ }^{2} J_{\mathrm{CP}}=4.2 \mathrm{~Hz}, \mathrm{Si}^{3} \mathrm{CH}_{2} \mathrm{CH}_{2} \mathrm{CH}_{2} \mathrm{P}$ ), 18.1 (d, $\left.{ }^{3} J_{\mathrm{CP}}=13.0 \mathrm{~Hz}, \mathrm{Si}^{3} \mathrm{CH}_{2} \mathrm{CH}_{2} \mathrm{CH}_{2} \mathrm{P}\right), 18.6\left(\mathrm{~s}, \mathrm{Si}^{0} \mathrm{CH}_{2}\right), 19.2\left(\mathrm{~d},{ }^{1} J_{\mathrm{CP}}=\right.$ $47.8 \mathrm{~Hz}, \mathrm{PCH}_{2} \mathrm{CH}_{2} \mathrm{CH}_{2} \mathrm{CH}_{3}$ ), (s, $\mathrm{Si}^{0} \mathrm{CH}_{2} \mathrm{CH}_{2}$ overlap), 19.3 (s, $\mathrm{Si}^{2} \mathrm{CH}_{2} \mathrm{CH}_{2} \mathrm{CH}_{2} \mathrm{Si}^{3}$ ), 19.5 (s, $\left.\mathrm{Si}^{1} \mathrm{CH}_{2} \mathrm{CH}_{2} \mathrm{CH}_{2} \mathrm{Si}^{2}\right), 19.6\left(\mathrm{~s}, \mathrm{Si}^{2} \mathrm{CH}_{2}-\right.$ $\mathrm{CH}_{2} \mathrm{CH}_{2} \mathrm{Si}^{3}$ ), $19.8\left(\mathrm{~s}, \mathrm{Si}^{1} \mathrm{CH}_{2} \mathrm{CH}_{2} \mathrm{CH}_{2} \mathrm{Si}^{2}\right), 20.0\left(\mathrm{~s}, \mathrm{Si}^{0} \mathrm{CH}_{2} \mathrm{CH}_{2}-\right.$ $\mathrm{CH}_{2}$ ), 20.7 (s, $\mathrm{Si}^{2} \mathrm{CH}_{2} \mathrm{CH}_{2} \mathrm{CH}_{2} \mathrm{Si}^{3}$ ), $23.2\left(\mathrm{~d},{ }^{1} J_{\mathrm{CP}}=44.9 \mathrm{~Hz}\right.$, $\mathrm{Si}^{3} \mathrm{CH}_{2} \mathrm{CH}_{2} \mathrm{CH}_{2} \mathrm{P}$ ), 24.2 (d, ${ }^{2} J_{\mathrm{CP}}=4.4 \mathrm{~Hz}, \mathrm{CH}_{3} \mathrm{CH}_{2} \mathrm{CH}_{2} \mathrm{CH}_{2} \mathrm{P}$ ), $24.6\left(\mathrm{~d},{ }^{3} J_{\mathrm{CP}}=15.5 \mathrm{~Hz}, \mathrm{CH}_{3} \mathrm{CH}_{2}\right) .{ }^{29} \mathrm{Si}\left\{{ }^{1} \mathrm{H}\right\}(59.60 \mathrm{MHz}): \delta\left(\mathrm{Si}^{0}\right.$ was not detected), $1.01\left(\mathrm{~s}, \mathrm{Si}^{1,2}\right), 1.53\left(\mathrm{~d},{ }^{4} J_{\mathrm{SiP}}=1.8 \mathrm{~Hz}, \mathrm{Si}^{3}\right) .{ }^{31} \mathrm{P}$ $\left\{{ }^{1} \mathrm{H}\right\}(202.37 \mathrm{MHz}): \delta$ 32.43. HRMS $\left(\mathrm{C}_{512} \mathrm{H}_{732} \mathrm{P}_{16} \mathrm{Si}_{29} \mathrm{I}_{16} \mathrm{O}_{48}\right)$ : $\left(\mathrm{ESI}^{+}\right) \mathrm{m} / \mathrm{z}:\left[\mathrm{M}-4 \mathrm{I}^{-}\right]^{4+}$ calcd for $\mathrm{C}_{512} \mathrm{H}_{732} \mathrm{P}_{16} \mathrm{Si}_{29} \mathrm{I}_{12} \mathrm{O}_{48}$ : 2621.8153 found: 2621.8113, $\left[\mathrm{M}-5 \mathrm{I}^{-}\right]^{5+}$ calcd for $\mathrm{C}_{512} \mathrm{H}_{732}$ $\mathrm{P}_{16} \mathrm{Si}_{29} \mathrm{I}_{11} \mathrm{O}_{48}: 2072.0712$ found: 2072.0691 , $\left[\mathrm{M}-6 \mathrm{I}^{-}\right]^{6+}$ calcd for $\mathrm{C}_{512} \mathrm{H}_{732} \mathrm{P}_{16} \mathrm{Si}_{29} \mathrm{I}_{10} \mathrm{O}_{48}: 1705.5750$ found: $1705.5777,\left[\mathrm{M}-7 \mathrm{I}^{-}\right]^{7+}$ calcd for $\mathrm{C}_{512} \mathrm{H}_{732} \mathrm{P}_{16} \mathrm{Si}_{29} \mathrm{I}_{9} \mathrm{O}_{48}: 1443.7923$ found: 1443.7899, [M - $8 \mathrm{I}]^{8+}$ calcd for $\mathrm{C}_{512} \mathrm{H}_{732} \mathrm{P}_{16} \mathrm{Si}_{29} \mathrm{I}_{8} \mathrm{O}_{48}: 1247.4551$ found: 1247.4601, $\left[\mathrm{M}-9 \mathrm{I}^{-}\right]^{9+}$ calcd for $\mathrm{C}_{512} \mathrm{H}_{732} \mathrm{P}_{16} \mathrm{Si}_{29} \mathrm{I}_{7} \mathrm{O}_{48}: 1094.7484$ found: $1094.7459,\left[\mathrm{M}-10 \mathrm{I}^{-}\right]^{10+}$ calcd for $\mathrm{C}_{512} \mathrm{H}_{732} \mathrm{P}_{16} \mathrm{Si}_{29} \mathrm{I}_{6} \mathrm{O}_{48}$ : 972.5831 found: $972.5753,\left[\mathrm{M}-11 \mathrm{I}^{-}\right]^{11+}$ calcd for $\mathrm{C}_{512} \mathrm{H}_{732} \mathrm{P}_{16^{-}}$ $\mathrm{Si}_{29} \mathrm{I}_{5} \mathrm{O}_{48}: 872.6296$ found: 872.6241, $\left[\mathrm{M}-12 \mathrm{I}^{-}\right]^{12+}$ calcd for $\mathrm{C}_{512} \mathrm{H}_{732} \mathrm{P}_{16} \mathrm{Si}_{29} \mathrm{I}_{4} \mathrm{O}_{48}: 789.3351$ found: 789.3337 , $\left[\mathrm{M}-13 \mathrm{I}^{-}\right]^{13+}$ calcd for $\mathrm{C}_{512} \mathrm{H}_{732} \mathrm{P}_{16} \mathrm{Si}_{29} \mathrm{I}_{3} \mathrm{O}_{48}: 718.8555$ found: 718.8503 .

4.2.29 Dendrimer (25). Data for 25: NMR (DMSO- $\left.d_{6}\right):{ }^{1} \mathrm{H}$ $(499.99 \mathrm{MHz}): \delta-0.16\left(\mathrm{~s}, 24 \mathrm{H}, \mathrm{Si}^{1} \mathrm{CH}_{3}\right), 0.39-0.43(\mathrm{~m}, 16 \mathrm{H}$, $\mathrm{Si}^{0} \mathrm{CH}_{2} \mathrm{CH}_{2} \mathrm{CH}_{2}$ ), 0.64-0.67 (m, 8H, $\left.\mathrm{CH}_{2} \mathrm{CH}_{2} \mathrm{CH}_{2} \mathrm{P}\right), 1.13-1.21(\mathrm{~m}$, $\left.8 \mathrm{H}, \mathrm{Si}^{0} \mathrm{CH}_{2} \mathrm{CH}_{2}\right), 1.45-1.50\left(\mathrm{~m}, 8 \mathrm{H}, \mathrm{CH}_{2} \mathrm{CH}_{2} \mathrm{P}\right), 3.37-3.42(\mathrm{~m}, 8 \mathrm{H}$, $\left.\mathrm{CH}_{2} \mathrm{P}\right), 3.86\left(\mathrm{~s}, 36 \mathrm{H}, \mathrm{OCH}_{3}\right), 7.26-7.28(\mathrm{~m}, 24 \mathrm{H}, \mathrm{CH}), 7.63-7.68$ $(\mathrm{m}, 24 \mathrm{H}, \mathrm{CH}) .{ }^{13} \mathrm{C}\left\{{ }^{1} \mathrm{H}\right\}(125.70 \mathrm{MHz}): \delta-3.7\left(\mathrm{~s}, \mathrm{Si}^{1} \mathrm{CH}_{3}\right), 16.6(\mathrm{~d}$, $\left.{ }^{3} J_{\mathrm{CP}}=13.8 \mathrm{~Hz}, \mathrm{CH}_{2} \mathrm{CH}_{2} \mathrm{CH}_{2} \mathrm{P}\right), 16.8\left(\mathrm{~s}, \mathrm{Si}^{0} \mathrm{CH}_{2}\right), 16.9\left(\mathrm{~d},{ }^{2} J_{\mathrm{CP}}=\right.$ $\left.4.1 \mathrm{~Hz}, \mathrm{CH}_{2} \mathrm{CH}_{2} \mathrm{P}\right), 18.0\left(\mathrm{~s}, \mathrm{Si}^{0} \mathrm{CH}_{2} \mathrm{CH}_{2}\right), 19.2\left(\mathrm{~s}, \mathrm{Si}^{0} \mathrm{CH}_{2} \mathrm{CH}_{2} \mathrm{CH}_{2}\right)$, $24.5\left(\mathrm{~d},{ }^{1} J_{\mathrm{CP}}=49.1 \mathrm{~Hz}, \mathrm{PCH}_{2}\right), 55.9\left(\mathrm{~s}, \mathrm{OCH}_{3}\right), 109.6\left(\mathrm{~d},{ }^{1} J_{\mathrm{CP}}=\right.$ $93.0 \mathrm{~Hz}, C \mathrm{P}), 115.8\left(\mathrm{~d},{ }^{3} J_{\mathrm{CP}}=13.5 \mathrm{~Hz}, C \mathrm{HCHCP}\right), 135.4\left(\mathrm{~d},{ }^{2} J_{\mathrm{CP}}=\right.$ $11.7 \mathrm{~Hz}, C \mathrm{HCP}), 163.9$ (d, $\left.{ }^{4} J_{\mathrm{CP}}=3.0 \mathrm{~Hz}, C_{\text {ipso }}\right) .{ }^{29} \mathrm{Si}\left\{{ }^{1} \mathrm{H}\right\}(99.31$ $\mathrm{MHz}): \delta 0.65\left(\mathrm{~s}, \mathrm{Si}^{0}\right), 1.49\left(\mathrm{~d},{ }^{4} J_{\mathrm{SiP}}=2.8 \mathrm{~Hz}, \mathrm{Si}^{1}\right) .{ }^{31} \mathrm{P}\left\{{ }^{1} \mathrm{H}\right\}(202.37$ $\mathrm{MHz}): \delta$ 20.63. HRMS $\left(\mathrm{C}_{116} \mathrm{H}_{156} \mathrm{P}_{4} \mathrm{Si}_{5} \mathrm{Cl}_{4} \mathrm{O}_{12}\right):\left(\mathrm{ESI}^{+}\right) \mathrm{m} / \mathrm{z}:[\mathrm{M}-$ $\left.\mathrm{Cl}^{-}\right]^{+}$calcd for $\mathrm{C}_{116} \mathrm{H}_{156} \mathrm{P}_{4} \mathrm{Si}_{5} \mathrm{Cl}_{3} \mathrm{O}_{12}: 2112.8474$ found: 2112.8485, $\left[\mathrm{M}-2 \mathrm{Cl}^{-}\right]^{2+}$ calcd for $\mathrm{C}_{116} \mathrm{H}_{156} \mathrm{P}_{4} \mathrm{Si}_{5} \mathrm{Cl}_{2} \mathrm{O}_{12}$ : 1038.4390 found: $1038.4388,\left[\mathrm{M}-3 \mathrm{Cl}^{-}\right]^{3+}$ calcd for $\mathrm{C}_{116} \mathrm{H}_{156}$ $\mathrm{P}_{4} \mathrm{Si}_{5} \mathrm{ClO}_{12}: 680.6365$ found: $680.6366,\left[\mathrm{M}-4 \mathrm{Cl}^{-}\right]^{4+}$ calcd for $\mathrm{C}_{116} \mathrm{H}_{156} \mathrm{P}_{4} \mathrm{Si}_{5} \mathrm{O}_{12}$ : 501.4849 found: 501.4846 .

4.2.30 Dendrimer (26). Data for 26: NMR (DMSO- $\left.d_{6}\right):{ }^{1} \mathrm{H}$ (499.99 MHz): $\delta-0.22\left(\mathrm{~s}, 12 \mathrm{H}, \mathrm{Si}^{1} \mathrm{CH}_{3}\right),-0.19\left(48 \mathrm{H}, \mathrm{Si}^{2} \mathrm{CH}_{3}\right)$, 0.39-0.42 (m, 48H, Si ${ }^{0} \mathrm{CH}_{2}, \mathrm{CH}_{2} \mathrm{Si}^{1} \mathrm{CH}_{2} \mathrm{CH}_{2} \mathrm{CH}_{2}$ ), 0.65-0.68 (m, $16 \mathrm{H}, \mathrm{CH}_{2} \mathrm{CH}_{2} \mathrm{CH}_{2} \mathrm{P}$ ), 1.18 (br s, $24 \mathrm{H}, \mathrm{CH}_{2} \mathrm{CH}_{2} \mathrm{Si}^{1} \mathrm{CH}_{2} \mathrm{CH}_{2}$ ), 1.46 (br s, $16 \mathrm{H}, \mathrm{CH}_{2} \mathrm{CH}_{2} \mathrm{P}$ ), 3.41-3.50 (m, 16H, $\left.\mathrm{CH}_{2} \mathrm{P}\right), 3.85(\mathrm{~s}, 72 \mathrm{H}$, $\left.\mathrm{OCH}_{3}\right), 7.24-7.27(\mathrm{~m}, 48 \mathrm{H} \mathrm{CH}), 7.66-7.69(\mathrm{~m}, 48 \mathrm{H}, \mathrm{CH}) .{ }^{13} \mathrm{C}\left\{{ }^{1} \mathrm{H}\right\}$ (125.70 MHz): $\delta-5.1\left(\mathrm{~s}, \mathrm{Si}^{1} \mathrm{CH}_{3}\right),-3.6\left(\mathrm{~s}, \mathrm{Si}^{2} \mathrm{CH}_{3}\right), 16.5\left(\mathrm{~d},{ }^{3} J_{\mathrm{CP}}=\right.$ $13.7 \mathrm{~Hz}, \mathrm{CH}_{2} \mathrm{CH}_{2} \mathrm{CH}_{2} \mathrm{P}$ ), 16.9 (d, ${ }^{2} J_{\mathrm{CP}}=4.4 \mathrm{~Hz}, \mathrm{CH}_{2} \mathrm{CH}_{2} \mathrm{P}$ ), 17.1 (s, $\mathrm{Si}^{0} \mathrm{CH}_{2}$ ), 17.9 (s, $\mathrm{Si}^{1} \mathrm{CH}_{2} \mathrm{CH}_{2} \mathrm{CH}_{2} \mathrm{Si}^{2}$ ), 18.1 (s, $\mathrm{Si}^{1} \mathrm{CH}_{2} \mathrm{CH}_{2}-$ $\mathrm{CH}_{2} \mathrm{Si}^{2}$ ), $18.2\left(\mathrm{~s}, \mathrm{Si}^{0} \mathrm{CH}_{2} \mathrm{CH}_{2}\right.$ ), 18.4 (s, $\mathrm{Si}^{0} \mathrm{CH}_{2} \mathrm{CH}_{2} \mathrm{CH}_{2}$ ), 19.2 (s, $\mathrm{Si}^{1} \mathrm{CH}_{2} \mathrm{CH}_{2} \mathrm{CH}_{2} \mathrm{Si}^{2}$ ), 24.5 (d, $\left.{ }^{1} J_{\mathrm{CP}}=49.1 \mathrm{~Hz}, \mathrm{CH}_{2} \mathrm{P}\right), 55.9(\mathrm{~s}$, $\left.\mathrm{OCH}_{3}\right), 109.6\left(\mathrm{~d},{ }^{1} J_{\mathrm{CP}}=93.1 \mathrm{~Hz}, C \mathrm{P}\right), 115.8\left(\mathrm{~d},{ }^{3} J_{\mathrm{CP}}=13.6 \mathrm{~Hz}\right.$, CHCHCP), 135.4 (d, $\left.{ }^{2} J_{\mathrm{CP}}=11.6 \mathrm{~Hz}, C \mathrm{HCP}\right), 163.9\left(\mathrm{~d},{ }^{4} J_{\mathrm{CP}}=\right.$ $\left.3.1 \mathrm{~Hz}, C_{\text {ipso }}\right) .{ }^{29} \mathrm{Si}\left\{{ }^{1} \mathrm{H}\right\}(99.31 \mathrm{MHz}): \delta\left(\mathrm{Si}^{0}\right.$ was not detected), $0.97\left(\mathrm{~s}, \mathrm{Si}^{1}\right), 1.44\left(\mathrm{~d},{ }^{4} J_{\mathrm{SiP}}=2.9 \mathrm{~Hz}, \mathrm{Si}^{2}\right) .{ }^{31} \mathrm{P}\left\{{ }^{1} \mathrm{H}\right\}(202.37 \mathrm{MHz})$ : $\delta$ 20.64. HRMS $\left(\mathrm{C}_{248} \mathrm{H}_{348} \mathrm{P}_{8} \mathrm{Si}_{13} \mathrm{Cl}_{8} \mathrm{O}_{24}\right):\left(\mathrm{ESI}^{+}\right) \mathrm{m} / \mathrm{z}:\left[\mathrm{M}-2 \mathrm{Cl}^{-}\right]^{2+}$ 
calcd for $\mathrm{C}_{248} \mathrm{H}_{348} \mathrm{P}_{8} \mathrm{Si}_{13} \mathrm{Cl}_{6} \mathrm{O}_{24}$ : 2269.4534 found: 2269.4517, [M $\left.-3 \mathrm{Cl}^{-}\right]^{3+}$ calcd for $\mathrm{C}_{248} \mathrm{H}_{348} \mathrm{P}_{8} \mathrm{Si}_{13} \mathrm{Cl}_{5} \mathrm{O}_{24}$ : 1500.9793 found: 1500.9760, $\left[\mathrm{M}-4 \mathrm{Cl}^{-}\right]^{4+}$ calcd for $\mathrm{C}_{248} \mathrm{H}_{348} \mathrm{P}_{8} \mathrm{Si}_{13} \mathrm{Cl}_{4} \mathrm{O}_{24}$ : 116.9923 found: 116.9917, $\left[\mathrm{M}-5 \mathrm{Cl}^{-}\right]^{5+}$ calcd for $\mathrm{C}_{248} \mathrm{H}_{348} \mathrm{P}_{8^{-}}$ $\mathrm{Si}_{13} \mathrm{Cl}_{3} \mathrm{O}_{24}$ : 886.4001 found: $886.3995,\left[\mathrm{M}-6 \mathrm{Cl}^{-}\right]^{6+}$ calcd for $\mathrm{C}_{248} \mathrm{H}_{348} \mathrm{P}_{8} \mathrm{Si}_{13} \mathrm{Cl}_{2} \mathrm{O}_{24}$ : 732.8386 found: $732.8341,\left[\mathrm{M}-7 \mathrm{Cl}^{-}\right]^{7+}$ calcd for $\mathrm{C}_{248} \mathrm{H}_{348} \mathrm{P}_{8} \mathrm{Si}_{13} \mathrm{ClO}_{24}$ : 623.0086 found: 623.0069 , [M $\left.8 \mathrm{Cl}^{-}\right]^{8+}$ calcd for $\mathrm{C}_{248} \mathrm{H}_{348} \mathrm{P}_{8} \mathrm{Si}_{13} \mathrm{O}_{24}: 540.7618$ found: 540.7604 .

4.2.31 Dendrimer (27). Data for 27: NMR (DMSO- $d_{6}$ ): ${ }^{1} \mathrm{H}$ (499.99 MHz): $\delta-0.23$ (br s, $132 \mathrm{H}, \mathrm{Si}^{1,2,3} \mathrm{CH}_{3}$ ), 0.39 (br s, $112 \mathrm{H}$, $\mathrm{Si}^{0} \mathrm{CH}_{2}, \mathrm{CH}_{2} \mathrm{Si}^{1} \mathrm{CH}_{2}, \mathrm{CH}_{2} \mathrm{Si}^{2} \mathrm{CH}_{2} \mathrm{CH}_{2} \mathrm{CH}_{2} \mathrm{Si}^{3}$ ), 0.67 (br s, 32H, $\mathrm{CH}_{2} \mathrm{CH}_{2} \mathrm{CH}_{2} \mathrm{P}$ ), 1.48 (br s, $56 \mathrm{H}, \quad \mathrm{CH}_{2} \mathrm{CH}_{2} \mathrm{Si}^{1} \mathrm{CH}_{2} \mathrm{CH}_{2}$ $\mathrm{CH}_{2} \mathrm{Si}^{2} \mathrm{CH}_{2} \mathrm{CH}_{2}$ ), 1.48 (br s, $32 \mathrm{H}, \mathrm{CH}_{2} \mathrm{CH}_{2} \mathrm{P}$ ), 3.51 (br s, $32 \mathrm{H}$, $\left.\mathrm{CH}_{2} \mathrm{P}\right), 3.83\left(\mathrm{~s}, 144 \mathrm{H}, \mathrm{OCH}_{3}\right), 7.22-7.24(\mathrm{~m}, 96 \mathrm{H}, \mathrm{CH}), 7.66-7.70$ $(\mathrm{m}, 96 \mathrm{H}, \mathrm{CH}) .{ }^{13} \mathrm{C}\left\{{ }^{1} \mathrm{H}\right\}(125.70 \mathrm{MHz}): \delta-5.1\left(\mathrm{~s}, \mathrm{Si}^{1,2} \mathrm{CH}_{3}\right),-3.7$ (s, $\left.\mathrm{Si}^{3} \mathrm{CH}_{3}\right), 16.4\left(\mathrm{~d},{ }^{3} J_{\mathrm{CP}}=13.4 \mathrm{~Hz}, \mathrm{CH}_{2} \mathrm{CH}_{2} \mathrm{CH}_{2} \mathrm{P}\right), 16.9\left(\mathrm{~d},{ }^{2} J_{\mathrm{CP}}=\right.$ $4.2 \mathrm{~Hz}, \mathrm{CH}_{2} \mathrm{CH}_{2} \mathrm{P}$ ); 17.9 (s, $\mathrm{Si}^{2} \mathrm{CH}_{2} \mathrm{CH}_{2} \mathrm{CH}_{2} \mathrm{Si}^{3}$ ); 18.1 (br s, $\mathrm{Si}^{1} \mathrm{CH}_{2} \mathrm{CH}_{2} \mathrm{CH}_{2} \mathrm{Si}^{2}$ ), 18.3 (s, $\mathrm{Si}^{2} \mathrm{CH}_{2} \mathrm{CH}_{2} \mathrm{CH}_{2} \mathrm{Si}^{3}$ ), 19.2 (s, $\mathrm{Si}^{2} \mathrm{CH}_{2}-$ $\left.\mathrm{CH}_{2} \mathrm{CH}_{2} \mathrm{Si}^{3}\right), 24.6\left(\mathrm{~d},{ }^{1} J_{\mathrm{CP}}=49.3 \mathrm{~Hz}, \mathrm{CH}_{2} \mathrm{P}\right), 55.9\left(\mathrm{~s}, \mathrm{OCH}_{3}\right), 109.6$ $\left(\mathrm{d},{ }^{1} J_{\mathrm{CP}}=85.2 \mathrm{~Hz}, C \mathrm{P}\right), 115.8\left(\mathrm{~d},{ }^{3} J_{\mathrm{CP}}=13.2 \mathrm{~Hz}, C \mathrm{HCHCP}\right), 135.4$ $\left(\mathrm{d},{ }^{2} J_{\mathrm{CP}}=11.6 \mathrm{~Hz}, \mathrm{CHCP}\right), 163.9$ (s, $\left.C_{\text {ipso }}\right),\left(\mathrm{Si}^{0} \mathrm{CH}_{2} \mathrm{CH}_{2} \mathrm{CH}_{2}\right.$ were not detected or overlap). ${ }^{29} \mathrm{Si}\left\{{ }^{1} \mathrm{H}\right\}$ (inept) (99.31 MHz): $\delta \mathrm{Si}^{0}$ was not detected, $0.91\left(\mathrm{~s}, \mathrm{Si}^{1,2}\right), 1.36\left(\mathrm{~d},{ }^{4} J_{\mathrm{SiP}}=2.9 \mathrm{~Hz}, \mathrm{Si}^{3}\right) .{ }^{31} \mathrm{P}\left\{{ }^{1} \mathrm{H}\right\}$ (202.37 MHz): $\delta$ 20.64. HRMS $\left(\mathrm{C}_{512} \mathrm{H}_{732} \mathrm{P}_{16} \mathrm{Si}_{29} \mathrm{Cl}_{16} \mathrm{O}_{48}\right):\left(\mathrm{ESI}^{+}\right) \mathrm{m} /$ $z:\left[\mathrm{M}-3 \mathrm{Cl}^{-}\right]^{3+}$ calcd for $\mathrm{C}_{512} \mathrm{H}_{732} \mathrm{P}_{16} \mathrm{Si}_{29} \mathrm{Cl}_{13} \mathrm{O}_{48}: 3141.9983$ found: $3142.0013,\left[\mathrm{M}-4 \mathrm{Cl}^{-}\right]^{4+}$ calcd for $\mathrm{C}_{512} \mathrm{H}_{732} \mathrm{P}_{16} \mathrm{Si}_{29} \mathrm{Cl}_{12}$ $\mathrm{O}_{48}$ : 2347.5066 found: $2347.5082,\left[\mathrm{M}-5 \mathrm{Cl}^{-}\right]^{5+}$ calcd for $\mathrm{C}_{512}$ $\mathrm{H}_{732} \mathrm{P}_{16} \mathrm{Si}_{29} \mathrm{Cl}_{11} \mathrm{O}_{48}: 1871.0115$ found: $1871.0099,\left[\mathrm{M}-6 \mathrm{Cl}^{-}\right]^{6+}$ calcd for $\mathrm{C}_{512} \mathrm{H}_{732} \mathrm{P}_{16} \mathrm{Si}_{29} \mathrm{Cl}_{10} \mathrm{O}_{48}: 1553.1815$ found: 1553.1836, $\left[\mathrm{M}-7 \mathrm{Cl}^{-}\right]^{7+}$ calcd for $\mathrm{C}_{512} \mathrm{H}_{732} \mathrm{P}_{16} \mathrm{Si}_{29} \mathrm{Cl}_{9} \mathrm{O}_{48}: 1326.3029$ found: 1326.3036, $\left[\mathrm{M}-8 \mathrm{Cl}^{-}\right]^{8+}$ calcd for $\mathrm{C}_{512} \mathrm{H}_{732} \mathrm{P}_{16} \mathrm{Si}_{29} \mathrm{Cl}_{8} \mathrm{O}_{48}$ : 1156.0189 found: $1156.0149,\left[\mathrm{M}-9 \mathrm{Cl}^{-}\right]^{9+}$ calcd for $\mathrm{C}_{512} \mathrm{H}_{732}{ }^{-}$ $\mathrm{P}_{16} \mathrm{Si}_{29} \mathrm{Cl}_{7} \mathrm{O}_{48}: 1023.6869$ found: $1023.6872,\left[\mathrm{M}-10 \mathrm{Cl}^{-}\right]^{10+}$ calcd for $\mathrm{C}_{512} \mathrm{H}_{732} \mathrm{P}_{16} \mathrm{Si}_{29} \mathrm{Cl}_{6} \mathrm{O}_{48}$ : 917.7214 found: 917.7234, [M $\left.11 \mathrm{Cl}^{-}\right]^{11+}$ calcd for $\mathrm{C}_{512} \mathrm{H}_{732} \mathrm{P}_{16} \mathrm{Si}_{29} \mathrm{Cl}_{5} \mathrm{O}_{48}$ : 831.1132 found: 831.1105, $\left[\mathrm{M}-12 \mathrm{Cl}^{-}\right]^{12+}$ calcd for $\mathrm{C}_{512} \mathrm{H}_{732} \mathrm{P}_{16} \mathrm{Si}_{29} \mathrm{Cl}_{4} \mathrm{O}_{48}$ : 758.8564 found: 758.8504, $\left[\mathrm{M}-13 \mathrm{Cl}^{-}\right]^{13+}$ calcd for $\mathrm{C}_{512} \mathrm{H}_{732}$ $\mathrm{P}_{16} \mathrm{Si}_{29} \mathrm{Cl}_{3} \mathrm{O}_{48}$ : 697.7929 found: 697.7889 .

4.2.32 Dendrimer (31). Data for 31: NMR (DMSO- $d_{6}$ ): ${ }^{1} \mathrm{H}$ $(400.13 \mathrm{MHz}): \delta-0.18\left(\mathrm{~s}, 24 \mathrm{H}, \mathrm{Si}^{1} \mathrm{CH}_{3}\right), 0.38-0.43(\mathrm{~m}, 16 \mathrm{H}$, $\left.\mathrm{Si}^{0} \mathrm{CH}_{2} \mathrm{CH}_{2} \mathrm{CH}_{2}\right), 0.66-0.70\left(\mathrm{~m}, 8 \mathrm{H}, \mathrm{CH}_{2} \mathrm{CH}_{2} \mathrm{CH}_{2} \mathrm{P}\right), 1.11-1.20(\mathrm{~m}$, $8 \mathrm{H}, \mathrm{Si}^{0} \mathrm{CH}_{2} \mathrm{CH}_{2}$ ), 1.45-1.55 (m, 8H, $\left.\mathrm{CH}_{2} \mathrm{CH}_{2} \mathrm{P}\right), 3.60-3.67(\mathrm{~m}, 8 \mathrm{H}$, $\left.\mathrm{CH}_{2} \mathrm{P}\right), 7.73-7.90(\mathrm{~m}, 60 \mathrm{H}, \mathrm{CH} \mathrm{Ph}) .{ }^{13} \mathrm{C}\left\{{ }^{1} \mathrm{H}\right\}(100.62 \mathrm{MHz}): \delta-3.7$ (s, $\mathrm{Si}^{1} \mathrm{CH}_{3}$ ), 16.6 (d, ${ }^{3} J_{\mathrm{CP}}=13.6 \mathrm{~Hz}, \mathrm{CH}_{2} \mathrm{CH}_{2} \mathrm{CH}_{2} \mathrm{P}$ ), 16.8 (s, $\mathrm{Si}^{0} \mathrm{CH}_{2}$ ), 17.0 (d, $\left.{ }^{2} J_{\mathrm{CP}}=4.6 \mathrm{~Hz}, \mathrm{CH}_{2} \mathrm{CH}_{2} \mathrm{P}\right), 18.0\left(\mathrm{~s}, \mathrm{Si}^{0} \mathrm{CH}_{2} \mathrm{CH}_{2}\right.$ ), $19.2\left(\mathrm{~s}, \mathrm{Si}^{0} \mathrm{CH}_{2} \mathrm{CH}_{2} \mathrm{CH}_{2}\right), 23.4\left(\mathrm{~d},{ }^{1} J_{\mathrm{CP}}=46.3 \mathrm{~Hz}, \mathrm{PCH}_{2}\right), 118.6$ (d, $\left.{ }^{1} J_{\mathrm{CP}}=85.3 \mathrm{~Hz}, C \mathrm{P}\right), 130.2\left(\mathrm{~d},{ }^{3} J_{\mathrm{CP}}=12.4 \mathrm{~Hz}, C \mathrm{HCHCP}\right), 133.6(\mathrm{~d}$, ${ }^{2} J_{\mathrm{CP}}=10.1 \mathrm{~Hz}, C \mathrm{HCP}$ ), 134.9 (d, ${ }^{4} J_{\mathrm{CP}}=2.6 \mathrm{~Hz}, C$ HCHCHCP). ${ }^{29} \mathrm{Si}\left\{{ }^{1} \mathrm{H}\right\}(79.49 \mathrm{MHz}): \delta 0.68\left(\mathrm{~s}, \mathrm{Si}^{0}\right), 1.56\left(\mathrm{~d},{ }^{4} J_{\mathrm{SiP}}=2.9 \mathrm{~Hz}, \mathrm{Si}^{1}\right)$. ${ }^{31} \mathrm{P}\left\{{ }^{1} \mathrm{H}\right\}(161.98 \mathrm{MHz}): \delta 22.99 . \mathrm{C}_{104} \mathrm{H}_{132} \mathrm{P}_{4} \mathrm{Si}_{5} \mathrm{Cl}_{4}\left(\mathrm{ESI}^{+}\right): \mathrm{m} / z$ calc. for $\left[\mathrm{C}_{104} \mathrm{H}_{132} \mathrm{P}_{4} \mathrm{Si}_{5} \mathrm{Cl}_{3}\right]^{+}$calc. 1751.7194 found 1751.7174; $\left[\mathrm{C}_{104}\right.$ $\left.\mathrm{H}_{132} \mathrm{P}_{4} \mathrm{Si}_{5} \mathrm{Cl}_{2}\right]^{2+}$ calc. 858.3754 found 858.3751; $\left[\mathrm{C}_{104} \mathrm{H}_{132} \mathrm{P}_{4} \mathrm{Si}_{5}\right.$ $\mathrm{Cl}]^{3+}$ calc. 560.5941 found $560.5945\left[\mathrm{C}_{104} \mathrm{H}_{132} \mathrm{P}_{4} \mathrm{Si}_{5}\right]^{4+}$ calc. 411.4532 found 411.4533 .

4.2.33 Dendrimer (32). Data for 32: NMR (DMSO- $d_{6}$ ): ${ }^{1} \mathrm{H}$ (499.99 MHz): $\delta-0.21$ (br s, $60 \mathrm{H}, \mathrm{Si}^{1} \mathrm{CH}_{3}, \mathrm{Si}^{2} \mathrm{CH}_{3}$ ), 0.38-0.49 (m, $48 \mathrm{H}, \mathrm{CH}_{2} \mathrm{CH}_{2} \mathrm{CH}_{2} \mathrm{Si}^{1} \mathrm{CH}_{2} \mathrm{CH}_{2} \mathrm{CH}_{2}$ ), 0.70-0.76 (m, 16H, $\mathrm{CH}_{2} \mathrm{CH}_{2}$
$\left.\mathrm{CH}_{2} \mathrm{P}\right), 1.12-1.27\left(\mathrm{~m}, 24 \mathrm{H}, \mathrm{CH}_{2} \mathrm{CH}_{2} \mathrm{Si}^{1} \mathrm{CH}_{2} \mathrm{CH}_{2}\right), 1.43-1.58(\mathrm{~m}$, $\left.16 \mathrm{H}, \mathrm{CH}_{2} \mathrm{CH}_{2} \mathrm{P}\right), 3.61-3.76\left(\mathrm{~m}, 16 \mathrm{H}, \mathrm{CH}_{2} \mathrm{P}\right), 7.71-7.89(\mathrm{~m}, 120 \mathrm{H}$, $\mathrm{CH} P h) .{ }^{13} \mathrm{C}\left\{{ }^{1} \mathrm{H}\right\}(125.70 \mathrm{MHz}): \delta-5.0\left(\mathrm{~s}, \mathrm{Si}^{1} \mathrm{CH}_{3}\right),-3.7(\mathrm{~s}$, $\mathrm{Si}^{2} \mathrm{CH}_{3}$ ), 16.5 (d, $\left.{ }^{3} J_{\mathrm{CP}}=13.4 \mathrm{~Hz}, \mathrm{CH}_{2} \mathrm{CH}_{2} \mathrm{CH}_{2} \mathrm{P}\right), 17.0\left(\mathrm{~d},{ }^{2} J_{\mathrm{CP}}=\right.$ $\left.4.7 \mathrm{~Hz}, \mathrm{CH}_{2} \mathrm{CH}_{2} \mathrm{P}\right), 17.1$ (s, $\left.\mathrm{Si}^{0} \mathrm{CH}_{2}\right), 17.9\left(\mathrm{~s}, \mathrm{Si}^{1} \mathrm{CH}_{2} \mathrm{CH}_{2} \mathrm{CH}_{2} \mathrm{Si}^{2}\right)$, 18.1 (s, $\mathrm{Si}^{1} \mathrm{CH}_{2} \mathrm{CH}_{2} \mathrm{CH}_{2} \mathrm{Si}^{2}$ ), 18.2 (s, $\mathrm{Si}^{0} \mathrm{CH}_{2} \mathrm{CH}_{2}$ ), 18.4 (s, $\mathrm{Si}^{0} \mathrm{CH}_{2} \mathrm{CH}_{2} \mathrm{CH}_{2}$ ), $19.2\left(\mathrm{~s}, \mathrm{Si}^{1} \mathrm{CH}_{2} \mathrm{CH}_{2} \mathrm{CH}_{2} \mathrm{Si}^{2}\right), 23.4$ (d, ${ }^{1} J_{\mathrm{CP}}=$ $46.0 \mathrm{~Hz}, \mathrm{CH}_{2} \mathrm{P}$ ), $118.6\left(\mathrm{~d},{ }^{1} J_{\mathrm{CP}}=85.3 \mathrm{~Hz}, C \mathrm{P}\right), 130.2\left(\mathrm{~d},{ }^{3} J_{\mathrm{CP}}=\right.$ $12.4 \mathrm{~Hz}, C \mathrm{HCHCP}$ ), 133.6 (d, ${ }^{2} J_{\mathrm{CP}}=10.2 \mathrm{~Hz}, C \mathrm{HCP}$ ), 134.8 (d, $\left.{ }^{4} J_{\mathrm{CP}}=3.2 \mathrm{~Hz}, C \mathrm{HCHCHCP}\right) .{ }^{29} \mathrm{Si}\left\{{ }^{1} \mathrm{H}\right\}(79.49 \mathrm{MHz}): \delta 0.70\left(\mathrm{~s}, \mathrm{Si}^{0}\right)$, $0.97\left(\mathrm{~s}, \mathrm{Si}^{1}\right), 1.48\left(\mathrm{~d},{ }^{4} J_{\mathrm{SiP}}=3.0 \mathrm{~Hz}, \mathrm{Si}^{2}\right) .{ }^{31} \mathrm{P}\left\{{ }^{1} \mathrm{H}\right\}(161.98 \mathrm{MHz})$ : $\delta$ 22.98. HRMS: $\left(\mathrm{ESI}^{+}\right): m / z$ calc. for $\mathrm{C}_{224} \mathrm{H}_{300} \mathrm{P}_{8} \mathrm{Si}_{13} \mathrm{Cl}_{8}\left(\mathrm{ESI}^{+}\right)$: $\left[\mathrm{C}_{224} \mathrm{H}_{300} \mathrm{P}_{8} \mathrm{Si}_{13} \mathrm{Cl}_{6}\right]^{2+}$ calc. 1908.8261 found 1908.8280; $\left[\mathrm{C}_{224}\right.$ $\left.\mathrm{H}_{300} \mathrm{P}_{8} \mathrm{Si}_{13} \mathrm{Cl}_{5}\right]^{3+}$ calc.1260.8945 found 1260.8946; $\left[\mathrm{C}_{224} \mathrm{H}_{300} \mathrm{P}_{8^{-}}\right.$ $\left.\mathrm{Si}_{13} \mathrm{Cl}_{4}\right]^{4+}$ calc. 936.6787 found 936.6796; $\left[\mathrm{C}_{224} \mathrm{H}_{300} \mathrm{P}_{8} \mathrm{Si}_{13} \mathrm{Cl}_{3}\right]^{5+}$ calc. 742.3492 found $742.3495 ; \quad\left[\mathrm{C}_{224} \mathrm{H}_{300} \mathrm{P}_{8} \mathrm{Si}_{13} \mathrm{Cl}_{2}\right]^{6+}$ calc. 612.6295 found 612.6282; $\left[\mathrm{C}_{224} \mathrm{H}_{300} \mathrm{P}_{8} \mathrm{Si}_{13} \mathrm{Cl}\right]^{7+}$ calc. 520.1155 found 520.1142; $\left[\mathrm{C}_{224} \mathrm{H}_{300} \mathrm{P}_{8} \mathrm{Si}_{13}\right]^{8+}$ calc. 450.6049 found 450.6046. Anal. calc. $\mathrm{C}_{224} \mathrm{H}_{300} \mathrm{Cl}_{8} \mathrm{P}_{8} \mathrm{Si}_{13}$ (3889.30 $\left.\mathrm{g} \mathrm{mol}{ }^{-1}\right): \mathrm{C}$, 69.17; H, 7.17; exp.: C, 69.82; H, 7.31.

4.2.34 Dendrimer (33). Data for 33: NMR (DMSO- $\left.d_{6}\right):{ }^{1} \mathrm{H}$ (400.13 MHz): $\delta-0.23$ (br s, $132 \mathrm{H}, \mathrm{Si}^{1,2,3} \mathrm{CH}_{3}$ ), 0.38-0.46 (m, $\left.112 \mathrm{H}, \quad \mathrm{CH}_{2} \mathrm{CH}_{2} \mathrm{CH}_{2} \mathrm{Si}^{1} \mathrm{CH}_{2} \mathrm{CH}_{2} \mathrm{CH}_{2} \mathrm{Si}^{2} \mathrm{CH}_{2} \mathrm{CH}_{2} \mathrm{CH}_{2}\right), \quad 0.64-0.72$ (m, 32H, $\left.\mathrm{CH}_{2} \mathrm{CH}_{2} \mathrm{CH}_{2} \mathrm{P}\right), 1.10-1.24\left(\mathrm{~m}, 56 \mathrm{H}, \mathrm{CH}_{2} \mathrm{CH}_{2} \mathrm{Si}^{1}\right.$ $\mathrm{CH}_{2} \mathrm{CH}_{2} \mathrm{CH}_{2} \mathrm{Si}^{2} \mathrm{CH}_{2} \mathrm{CH}_{2}$ ), 1.42-1.55 (m, 32H, $\left.\mathrm{CH}_{2} \mathrm{CH}_{2} \mathrm{P}\right), 3.67-$ $3.81\left(\mathrm{~m}, 32 \mathrm{H}, \mathrm{CH}_{2} \mathrm{P}\right), 7.69-7.85(\mathrm{~m}, 240 \mathrm{H}, \mathrm{CH} P h) .{ }^{13} \mathrm{C}\left\{{ }^{1} \mathrm{H}\right\}$ (100.62 MHz): $\delta-5.0\left(\mathrm{~s}, \mathrm{Si}^{1,2} \mathrm{CH}_{3}\right),-3.7\left(\mathrm{~s}, \mathrm{Si}^{3} \mathrm{CH}_{3}\right), 16.4\left(\mathrm{~d},{ }^{3} J_{\mathrm{CP}}\right.$ $\left.=13.8 \mathrm{~Hz}, \mathrm{CH}_{2} \mathrm{CH}_{2} \mathrm{CH}_{2} \mathrm{P}\right), 17.0\left(\mathrm{~d},{ }^{2} J_{\mathrm{CP}}=4.5 \mathrm{~Hz}, \mathrm{CH}_{2} \mathrm{CH}_{2} \mathrm{P}\right), 17.9$ (s, $\left.\mathrm{Si}^{2} \mathrm{CH}_{2} \mathrm{CH}_{2} \mathrm{CH}_{2} \mathrm{Si}^{3}\right),\left(\mathrm{Si}^{0} \mathrm{CH}_{2} \mathrm{CH}_{2} \mathrm{CH}_{2}\right.$ were not detected or overlap), 18.07 (s, $\mathrm{Si}^{1} \mathrm{CH}_{2} \mathrm{CH}_{2} \mathrm{CH}_{2} \mathrm{Si}^{2}$ ), $18.12\left(\mathrm{~s}, \mathrm{Si}^{2} \mathrm{CH}_{2} \mathrm{CH}_{2} \mathrm{CH}_{2}\right.$ $\mathrm{Si}^{3}$ ), $18.3\left(\mathrm{~s}, \mathrm{Si}^{1} \mathrm{CH}_{2} \mathrm{CH}_{2} \mathrm{CH}_{2} \mathrm{Si}^{2}\right), 19.2\left(\mathrm{~s}, \mathrm{Si}^{2} \mathrm{CH}_{2} \mathrm{CH}_{2} \mathrm{CH}_{2} \mathrm{Si}^{3}\right), 23.4$ $\left(\mathrm{d},{ }^{1} J_{\mathrm{CP}}=45.9 \mathrm{~Hz}, C \mathrm{H}_{2} \mathrm{P}\right), 118.7\left(\mathrm{~d},{ }^{1} J_{\mathrm{CP}}=85.2 \mathrm{~Hz}, C \mathrm{P}\right), 130.1(\mathrm{~d}$, $\left.{ }^{3} J_{\mathrm{CP}}=12.4 \mathrm{~Hz}, C \mathrm{HCHCP}\right), 133.6\left(\mathrm{~d},{ }^{2} J_{\mathrm{CP}}=10.1 \mathrm{~Hz}, C \mathrm{HCP}\right), 134.8$ (d, $\left.{ }^{4} J_{\mathrm{CP}}=2.0 \mathrm{~Hz}, C \mathrm{HCHCHCP}\right) .{ }^{29} \mathrm{Si}\left\{{ }^{1} \mathrm{H}\right\}(79.49 \mathrm{MHz}): \delta \mathrm{Si}^{0}$ was not detected, $0.94\left(\mathrm{~s}, \mathrm{Si}^{1}, \mathrm{Si}^{2}\right), 1.42\left(\mathrm{~d},{ }^{4} J_{\mathrm{SiP}}=3.0 \mathrm{~Hz}, \mathrm{Si}^{3}\right) .{ }^{31} \mathrm{P}\left\{{ }^{1} \mathrm{H}\right\}$ (161.98 MHz): $\delta$ 23.02. HRMS: $\left(\right.$ ESI $\left.^{+}\right): m / z$ calcd for $\mathrm{C}_{464} \mathrm{H}_{636}$ $\mathrm{P}_{16} \mathrm{Si}_{29} \mathrm{Cl}_{16}\left(\mathrm{ESI}^{+}\right):\left[\mathrm{C}_{464} \mathrm{H}_{636} \mathrm{P}_{16} \mathrm{Si}_{29} \mathrm{Cl}_{13}\right]^{3+}$ calc. 2661.4953 found 2661.4946; $\left[\mathrm{C}_{464} \mathrm{H}_{636} \mathrm{P}_{16} \mathrm{Si}_{29} \mathrm{Cl}_{12}\right]^{4+}$ calc. 1987.1293 found 1987.1277; $\left[\mathrm{C}_{464} \mathrm{H}_{636} \mathrm{P}_{16} \mathrm{Si}_{29} \mathrm{Cl}_{11}\right]^{5+}$ calc. 1582.7097 found 1582.7090; $\left[\mathrm{C}_{464} \mathrm{H}_{636} \mathrm{P}_{16} \mathrm{Si}_{29} \mathrm{Cl}_{10}\right]^{6+}$ calc. 1312.9299 found 1312.9299; $\left[\mathrm{C}_{464} \mathrm{H}_{636} \mathrm{P}_{16} \mathrm{Si}_{29} \mathrm{Cl}_{9}\right]^{7+}$ calc. 1120.3730 found 1120.3722; $\quad\left[\mathrm{C}_{464} \mathrm{H}_{636} \mathrm{P}_{16} \mathrm{Si}_{29} \mathrm{Cl}_{8}\right]^{8+}$ calc. 975.8303 found 975.8358; $\left[\mathrm{C}_{464} \mathrm{H}_{636} \mathrm{P}_{16} \mathrm{Si}_{29} \mathrm{Cl}_{7}\right]^{9+}$ calc. 863.5192 found 863.5160; $\left[\mathrm{C}_{464} \mathrm{H}_{636} \mathrm{P}_{16} \mathrm{Si}_{29} \mathrm{Cl}_{6}\right]^{10+}$ calc. 773.6705 found 773.6698; $\left[\mathrm{C}_{464}\right.$ $\left.\mathrm{H}_{636} \mathrm{P}_{16} \mathrm{Si}_{29} \mathrm{Cl}_{5}\right]^{11+}$ calc. 700.0669 found 700.0637; $\left[\mathrm{C}_{464} \mathrm{H}_{636} \mathrm{P}_{16}\right.$ $\left.\mathrm{Si}_{29} \mathrm{Cl}_{4}\right]^{12+}$ calc. 638.8139 found $638.8103 ;\left[\mathrm{C}_{464} \mathrm{H}_{636} \mathrm{P}_{16} \mathrm{Si}_{29} \mathrm{Cl}_{3}\right]^{13+}$ calc. 586.9075 found 586.9050 .

\subsection{Computer modelling of dendrimers}

3D computer models of dendrimer structures were created using dendrimer builder, as implemented in the Materials Studio software package from BIOVIA (formerly Accelrys). The RESP technique ${ }^{52}$ was used for calculation of dendrimer atoms partial charges. For this charge parametrisation the R.E.D.-IV tools $^{53}$ was used. The necessary QM calculations (QM structure minimisations, molecular electrostatic potential (MEP) 
calculations) were done using GAMESS. ${ }^{54,55}$ The default, HF/6$31 \mathrm{G}^{*}$, level of theory was used for all charge-related QM calculations and the MEP potential was fitted on Connolly molecular surface. GAFF force field (Generalized Amber Force Field), was used for parametrization of dendrimers. ${ }^{56}$ Missing force field parameters were fitted by minimizing the differences between $\mathrm{QM}$ and force field based relative energies of properly chosen molecular fragments. QM energies were calculated at MP2/HF/ $6-31 \mathrm{G}^{* *}$ level of theory using GAMESS and fitting was accomplished using paramfit routine from AMBER14 software. ${ }^{57}$ Slightly adjusted van der Waals parameters for Si atoms from MM3 force field were used in this study. ${ }^{58}$ Dendrimer models were solvated in explicit water (TIP3P model) with the proper number of $\mathrm{Na}^{+}$and $\mathrm{Cl}^{-}$ions to preserve neutrality of the system and to ensure the physiological ionic strength $(0.15 \mathrm{M}){ }^{59}$ First the systems were minimized (5000 steps with $2 \mathrm{kcal}\left(\mathrm{mol} \AA^{2}\right)^{-1}$ restraint +5000 without restraint), heated (200 ps NVT) to $294 \mathrm{~K}$ and equilibrated using $70 \mathrm{~ns}$ long molecular dynamics simulations (NPT, $T=294 \mathrm{~K}, P=0.1 \mathrm{MPa}$ ). The first $0.5 \mathrm{~ns}$ with restrained solute. Hydrogens were constrained with the SHAKE algorithm to allow 2 fs time step ${ }^{60}$ and Langevin thermostat with collision frequency $2 \mathrm{ps}^{-1}$ was used for all MD runs. ${ }^{61}$ The pressure relaxation time for weak-coupling barostat was 2 ps. Particle mesh Ewald method (PME) was used to treat long range electrostatic interactions under periodic conditions with a direct space cutoff of 10 Angstroms. The same cutoff was used for van der Waals interactions. The pmemd.cuda module from Amber14 package was used for all simulation steps. ${ }^{62}$ Radial distribution function calculations were done using last $20 \mathrm{~ns}$ of MD trajectory (2000 frames analyzed). In case of size characteristics calculations $\left(R_{\mathrm{g}}, R_{\max }\right)$ last $40 \mathrm{~ns}$ was used (80 frames analyzed). The cpptraj module from Amber14 was used for last mentioned analysis. ${ }^{63}$ Adaptive Poisson Boltzmann Solver (APBS) was used for electrostatic potential calculation. ${ }^{64}$ Chimera software was used for all visualizations. ${ }^{65}$

\subsection{In vitro toxicity evaluation}

4.4.1 Cell culture. B14 cells (Cricetulus griseus, ATCC, CCL14.1, Sigma-Aldrich Inc.) were grown in High glucose DMEM medium with $10 \%(\mathrm{v} / \mathrm{v})$ fetal bovine serum (FBS) and $4 \mathrm{mM}$ glutamine, BRL 3A (Rattus norvegicus, ATCC, CRL-1442, SigmaAldrich Inc.) in Ham's F12 medium with $10 \%$ (v/v) FBS and $2 \mathrm{mM}$ glutamine, and NRK 52E (Rattus norvegicus, ATCC, CRL1571, Sigma-Aldrich Inc.) in high glucose DMEM with $2 \mathrm{mM}$ glutamine, $10 \%(\mathrm{v} / \mathrm{v})$ new born calf serum (NBCS) and 1\% (v/v) nonessential amino acid solution (NEAA), all media were supplemented with $0.1 \%(\mathrm{w} / \mathrm{v})$ penicillin and $0.1 \%(\mathrm{w} / \mathrm{v})$ streptomycin. The cells were maintained in culture flasks in a $37{ }^{\circ} \mathrm{C}$ humidified atmosphere of $5 \% \mathrm{CO}_{2} / 95 \%$ air (incubator) and passaged every 2-3 days. Cells were harvested and used in experiments after obtaining $80-90 \%$ confluence. The number of viable cells was determined by trypan blue exclusion on a haemocytometer. Then cells were suspended in media in a concentration of $1.0 \times 10^{5}$ cells per $\mathrm{mL}$ and plated in flat bottom 96-well plates. Plates with cells were incubated $24 \mathrm{~h}$ at a $37{ }^{\circ} \mathrm{C}$ in a humidified atmosphere of $5 \% \mathrm{CO}_{2}$ to allow adherence of the cells before the administration of dendrimers.

4.4.2 MTT assay. Cytotoxicity of dendrimers was assayed with MTT (3-(4,5-dimethylthiazol-2-yl)-2,5-diphenyltetrazoliumbromide). Briefly, after $24 \mathrm{~h}$ incubation when cells attached on 96-well plates they were treated with concentration range from 0.5 to $20 \mu \mathrm{M}$ carbosilane dendrimers. After $24 \mathrm{~h}$ incubation, a solution of MTT in PBS was added to each well. Four hours later the medium was removed and the formazan precipitate dissolved in DMSO for absorbance measurement at $580 \mathrm{~nm}$ and reference $700 \mathrm{~nm}$. Viability is given graphically as a percent of the control values (without dendrimers).

4.4.3 Crystal violet staining assay (CVS). The cytotoxicity effect was also evaluated by crystal violet assay. Cells were seeded in 96-well plates and were grown in $100 \mu \mathrm{l}$ of appropriate growth medium for $24 \mathrm{~h}$. Then cells were treated with carbosilane dendrimers as it has been done in a MMT assay. After $24 \mathrm{~h}$ incubation cells were washed by phosphate buffer and $50 \mu \mathrm{l}$ of $0.05 \%$ crystal violet solution in $20 \%$ methanol was added. Cells had been incubated with staining solution for $30 \mathrm{~min}$ and after incubation double washed with distilled water and left to dry. After drying process the crystal violet was washed from dry cells by methanol and the absorbance was measured at $570 \mathrm{~nm}$ and reference $700 \mathrm{~nm}$. Viability is given graphically as a percent of the control values (without dendrimers).

\section{5 $\mathrm{IC}_{50}$ calculations}

The $\mathrm{IC}_{50}$ values (concentration of dendrimers which inhibit the cell viability to $50 \%$ of the control sample) were calculated from the best fit of experimental data with four-parameter logistic function (4PL function, $R^{2}>0.95$ ) using nonlinear regression analysis in Graph Pad Prism software (GraphPad Software, Inc. USA, version 7):

$$
Y=100 /\left(1+\left(X^{\text {HillSlope }}\right) /\left(\mathrm{IC}_{50}{ }^{\text {HillSlope }}\right)\right)
$$

where $X=\log$ of dendrimer concentration, $Y=$ growth inhibition value normalized to control and the Hillslope represent unitless factor.

\subsection{Statistical analysis}

Measured data are presented as the mean value \pm standard deviation (error bars, S.D.). Each experimental variant was conducted in at least three independent runs. The statistical analysis was performed with GraphPad Prism 7 (GraphPad Software, Inc, USA) software using an unpaired $t$-test or one-way ANOVA followed with Tukey-Kramer multiply comparison test. $p<0.05$ was considered statistically significant.

\section{Acknowledgements}

The authors acknowledge the project No. 15-05903S of the Czech Science Foundation and project of the Internal Grant Agency of UJEP. The authors also acknowledge the assistance provided by the Research Infrastructure NanoEnviCz, 
supported by the Ministry of Education, Youth and Sports of the Czech Republic under Project No. LM2015073.

\section{References}

1 J. M. Oliveira, A. J. Salgado, N. Sousa, J. F. Mano and R. L. Reis, Prog. Polym. Sci., 2010, 35, 1163-1194.

2 V. Gajbhiye, V. K. Palanirajan, R. K. Tekade and N. K. Jain, J. Pharm. Pharmacol., 2009, 61, 989-1003.

3 C. Dufès, I. F. Uchegbu and A. G. Schätzlein, Adv. Drug Delivery Rev., 2005, 57, 2177-2202.

4 D. Shcharbin, E. Pedziwiatr, J. Blasiak and M. Bryszewska, J. Controlled Release, 2010, 141, 110-127.

5 A. J. Salgado, J. M. Oliveira, R. P. Pirraco, V. H. Pereira, J. S. Fraga, A. P. Marques, N. M. Neves, J. F. Mano, R. L. Reis and N. Sousa, Macromol. Biosci., 2010, 10, 11301140.

6 A. M. Caminade, C. O. Turrin and J. P. Majoral, Chemistry, 2008, 14, 7422-7432.

7 K. Jain, P. Kesharwani, U. Gupta and N. K. Jain, Int. J. Pharm., 2010, 394, 122-142.

8 J. Maly, H. Lampova, A. Semeradtova, M. Stofik and L. Kovacik, Nanotechnology, 2009, 20, 385101.

9 S. Zhu, M. Hong, L. Zhang, G. Tang, Y. Jiang and Y. Pei, Pharm. Res., 2010, 27, 161-174.

10 Y. Zhao, S. Liu, Y. Li, W. Jiang, Y. Chang, S. Pan, X. Fang, Y. A. Wang and J. Wang, J. Colloid Interface Sci., 2010, 350, 44-50.

11 K. Hatano, K. Matsuoka and D. Terunuma, Chem. Soc. Rev., 2013, 42(11), 4574-4598.

12 D. Wrobel, D. Appelhans, M. Signorelli, B. Wiesner, D. Fessas, U. Scheler, B. Voit and J. Maly, Biochim. Biophys. Acta, Biomembr., 2015, 1848, 1490-1501.

13 D. Wrobel, A. Janaszewska, D. Appelhans, B. Voit, M. Bryszewska and J. Maly, Int. J. Pharm., 2015, 496, 475-488.

14 J. Maly, E. Pedziwiatr-Werbicka, M. Maly, A. Semeradtova, D. Appelhans, A. Danani, M. Zaborski, B. Klajnert and M. Bryszewska, Curr. Med. Chem., 2012, 19, 4708-4719.

15 H. B. Agashe, T. Dutta, M. Garg and N. K. Jain, J. Pharm. Pharmacol., 2006, 58, 1491-1498.

16 S. Nimesh, A. Aggarwal, P. Kumar, Y. Singh, K. C. Gupta and R. Chandra, Int. J. Pharm., 2007, 337, 265-274.

17 J. Maly, O. Stanek, J. Frolik, M. Maly, F. Ennen, D. Appelhans, A. Semeradtova, D. Wrobel, M. Stofik, T. Knapova, M. Kuchar, L. C. Stastna, J. Cermak, P. Sebo and P. Maly, Macromol. Biosci., 2016, 16, 553-566.

18 Y. Hirayama, T. Nakamura, S. Uehara, Y. Sakamoto, K. Yamaguchi, Y. Sei and M. Iwamura, Org. Lett., 2005, 7, 525-528.

19 T. R. Krishna, S. Jain, U. S. Tatu and N. Jayaraman, Tetrahedron, 2005, 61, 4281-4288.

20 D. M. Domański, M. Bryszewska and G. Salamończyk, Biomacromolecules, 2004, 5, 2007-2012.

21 L.-L. Lai, C.-H. Lee, L.-Y. Wang, K.-L. Cheng and H.-F. Hsu, J. Org. Chem., 2007, 73, 485-490.

22 J. Lim and E. E. Simanek, Adv. Drug Delivery Rev., 2012, 64, 826-835.
23 E. Pedziwiatr-Werbicka, D. Shcharbin, J. Maly, M. Maly, M. Zaborski, B. Gabara, P. Ortega, F. J. de la Mata, R. Gomez, M. A. Munoz-Fernandez, B. Klajnert and M. Bryszewska, J. Biomed. Nanotechnol., 2012, 8, 57-73.

24 R. Gomez, F. J. de la Mata, J. L. Jimenez-Fuentes, P. Ortega,

B. Klajnert, E. Pedziwiatr-Werbicka, D. Shcharbin, M. Bryszewska, M. Maly, J. Maly, M. J. Serramia, R. Lorente and M. A. Munoz-Fernandez, in Dendrimers in Biomedical Applications, The Royal Society of Chemistry, 2013, pp. 4055, DOI: 10.1039/9781849737296-00040.

25 L. Chonco, J. F. Bermejo-Martin, P. Ortega, D. Shcharbin, E. Pedziwiatr, B. Klajnert, F. J. de la Mata, R. Eritja, R. Gomez, M. Bryszewska and M. A. Munoz-Fernandez, Org. Biomol. Chem., 2007, 5, 1886-1893.

26 E. Pedziwiatr, D. Shcharbin, L. Chonco, P. Ortega, F. J. de la Mata, R. Gomez, B. Klajnert, M. Bryszewska and M. A. Munoz-Fernandez, J. Fluoresc., 2009, 19, 267-275.

27 J. F. Bermejo, P. Ortega, L. Chonco, R. Eritja, R. Samaniego, M. Mullner, E. de Jesus, F. J. de la Mata, J. C. Flores, R. Gomez and A. Munoz-Fernandez, Chemistry, 2007, 13, 483-495.

28 M. J. Serramia, S. Alvarez, E. Fuentes-Paniagua, M. I. Clemente, J. Sanchez-Nieves, R. Gomez, J. de la Mata and M. A. Munoz-Fernandez, J. Controlled Release, 2015, 200, 60-70.

29 S. T. Hemp, A. E. Smith, J. M. Bryson, M. H. Allen Jr and T. E. Long, Biomacromolecules, 2012, 13, 2439-2445.

30 C. Ornelas-Megiatto, P. R. Wich and J. M. Frechet, J. Am. Chem. Soc., 2012, 134, 1902-1905.

31 S. T. Hemp, M. H. Allen Jr, M. D. Green and T. E. Long, Biomacromolecules, 2012, 13, 231-238.

32 E. Guénin, A.-C. Hervé, V. Floch, S. Loisel, J.-J. Yaouanc, J.-C. Clément, C. Férec and H. des Abbayes, Angew. Chem., Int. Ed., 2000, 39, 629-631.

33 V. Floch, S. Loisel, E. Guenin, A. C. Hervé, J. C. Clément, J. J. Yaouanc, H. des Abbayes and C. Férec, J. Med. Chem., 2000, 43, 4617-4628.

34 E. Picquet, K. Le Ny, P. Delépine, T. Montier, J.-J. Yaouanc, D. Cartier, H. des Abbayes, C. Férec and J.-C. Clément, Bioconjugate Chem., 2005, 16, 1051-1053.

35 M.-A. Lacour, M. Zablocka, A.-M. Caminade, M. Taillefer and J.-P. Majoral, Tetrahedron Lett., 2009, 50, 4870-4873.

36 X. Wang, N. Shao, Q. Zhang and Y. Cheng, J. Mater. Chem. B, 2014, 2, 2546-2553.

37 S. Biswas, N. S. Dodwadkar, A. Piroyan and V. P. Torchilin, Biomaterials, 2012, 33, 4773-4782.

38 A. Krupková and J. Čermák, J. Inorg. Organomet. Polym. Mater., 2011, 22, 470-477.

39 T. Strašák, J. Čermák, J. Sýkora, J. Horský, Z. Walterová, F. Jaroschik and D. Harakat, Organometallics, 2012, 31, 6779-6786.

40 A. Krupková, J. Čermák, Z. Walterová and J. Horský, Anal. Chem., 2007, 79, 1639-1645.

41 A. Krupková, J. Čermák, Z. Walterová and J. I. Horský, Macromolecules, 2010, 43, 4511-4519. 
42 E. Arnáiz, L. I. Doucede, S. García-Gallego, K. Urbiola, R. Gómez, C. Tros de Ilarduya and F. J. de la Mata, Mol. Pharm., 2012, 9, 433-447.

43 P. Ortega, B. M. Cobaleda, J. M. Hernandez-Ros, E. FuentesPaniagua, J. Sanchez-Nieves, M. a. P. Tarazona, J. L. CopaPatino, J. Soliveri, F. J. de la Mata and R. Gomez, Org. Biomol. Chem., 2011, 9, 5238-5248.

44 H. K. Haruo Nakayama, N. Yamamoto, Y. Akagi and H. Matsui, Bull. Chem. Soc. Jpn., 1989, 62, 985-992.

45 D. Appelhans, B. Klajnert-Maculewicz, A. Janaszewska, J. Lazniewska and B. Voit, Chem. Soc. Rev., 2015, 44, 39683996.

46 A. Janaszewska, K. Maczynska, G. Matuszko, D. Appelhans, B. Voit, B. Klajnert and M. Bryszewska, New J. Chem., 2012, 36, 428-437.

47 S. V. Boddapati, P. Tongcharoensirikul, R. N. Hanson, G. G. M. D'Souza, V. P. Torchilin and V. Weissig, J. Liposome Res., 2005, 15, 49-58.

48 L. Sliwka, K. Wiktorska, P. Suchocki, M. Milczarek, S. Mielczarek, K. Lubelska, T. Cierpial, P. Lyzwa, P. Kielbasinski, A. Jaromin, A. Flis and Z. Chilmonczyk, PLoS One, 2016, 11, e0155772.

49 K. Chiba, K. Kawakami and K. Tohyama, Toxicol. in Vitro, 1998, 12, 251-258.

50 J. O. Daiss, S. Duda-Johner, C. Burschka, U. Holzgrabe, K. Mohr and R. Tacke, Organometallics, 2002, 21, 803-811.

51 A. W. van der Made, P. W. N. M. van Leeuwen, J. C. de Wilde and R. A. C. Brandes, Adv. Mater., 1993, 5, 466-468.

52 C. I. Bayly, P. Cieplak, W. Cornell and P. A. Kollman, J. Phys. Chem., 1993, 97, 10269-10280.

53 F.-Y. Dupradeau, A. Pigache, T. Zaffran, C. Savineau, R. Lelong, N. Grivel, D. Lelong, W. Rosanski and P. Cieplak, Phys. Chem. Chem. Phys., 2010, 12, 7821-7839.

54 M. W. Schmidt, K. K. Baldridge, J. A. Boatz, S. T. Elbert, M. S. Gordon, J. H. Jensen, S. Koseki, N. Matsunaga, K. A. Nguyen, S. Su, T. L. Windus, M. Dupuis and J. A. Montgomery Jr, J. Comput. Chem., 1993, 14, 1347-1363.
55 M. S. Gordon and M. W. Schmidt, in Theory and Applications of Computational Chemistry: the first forty years, ed. C. E. Dykstra, G. Frenking, K. S. Kim and G. E. Scuseria, Elsevier, 2005, pp. 1167-1189, DOI: citeulike-articleid:3013672.

56 J. Wang, R. M. Wolf, J. W. Caldwell, P. A. Kollman and D. A. Case, J. Comput. Chem., 2004, 25, 1157-1174.

57 D. A. Case, R. M. Betz, W. Botello-Smith, D. S. Cerutti, T. E. Cheatham III, T. A. Darden, R. E. Duke, T. J. Giese, H. Gohlke, A. W. Goetz, N. Homeyer, S. Izadi, P. Janowski, J. Kaus, A. Kovalenko, T. S. Lee, S. LeGrand, P. Li, C. Lin, T. Luchko, R. Luo, B. Madej, D. Mermelstein, K. M. Merz, G. Monard, H. Nguyen, H. T. Nguyen, I. Omelyan, A. Onufriev, D. R. Roe, A. Roitberg, C. Sagui, C. L. Simmerling, J. Swails, R. C. Walker, J. Wang, R. M. Wolf, X. Wu, L. Xiao, D. M. York and P. A. Kollman, AMBER 2016, University of California, San Francisco, 2016.

58 J.-H. Lii and N. L. Allinger, J. Comput. Chem., 1991, 12, 186199.

59 W. L. Jorgensen, J. Chandrasekhar, J. D. Madura, R. W. Impey and M. L. Klein, J. Chem. Phys., 1983, 79, 926935.

60 J.-P. Ryckaert, G. Ciccotti and H. J. C. Berendsen, J. Comput. Phys., 1977, 23, 327-341.

61 X. Wu and B. R. Brooks, Chem. Phys. Lett., 2003, 381, 512518.

62 A. W. Gotz, M. J. Williamson, D. Xu, D. Poole, S. Le Grand and R. C. Walker, J. Chem. Theory Comput., 2012, 8, 15421555.

63 D. R. Roe and T. E. Cheatham, J. Chem. Theory Comput., 2013, 9, 3084-3095.

64 N. A. Baker, D. Sept, S. Joseph, M. J. Holst and J. A. McCammon, Proc. Natl. Acad. Sci. U. S. A., 2001, 98, 10037-10041.

65 E. F. Pettersen, T. D. Goddard, C. C. Huang, G. S. Couch, D. M. Greenblatt, E. C. Meng and T. E. Ferrin, J. Comput. Chem., 2004, 25, 1605-1612. 